\title{
Cultural Resources Investigations for the CrownQuest City of Midland Oil and Gas Project, Midland and Glasscock Counties, Texas
}

Sophia Salgado

Zachary Overfield

Cody Roush

Follow this and additional works at: https://scholarworks.sfasu.edu/ita

Part of the American Material Culture Commons, Archaeological Anthropology Commons, Environmental Studies Commons, Other American Studies Commons, Other Arts and Humanities Commons, Other History of Art, Architecture, and Archaeology Commons, and the United States History Commons

Tell us how this article helped you.

This Article is brought to you for free and open access by the Center for Regional Heritage Research at SFA ScholarWorks. It has been accepted for inclusion in Index of Texas Archaeology: Open Access Gray Literature from the Lone Star State by an authorized editor of SFA ScholarWorks. For more information, please contact cdsscholarworks@sfasu.edu. 
Cultural Resources Investigations for the CrownQuest City of Midland Oil and Gas Project, Midland and Glasscock Counties, Texas

\section{Creative Commons License}

\section{(c) (1) \&}

This work is licensed under a Creative Commons Attribution-NonCommercial 4.0 International License 


\section{Cultural Resources Investigations for the CrownQuest City of Midland Oil and Gas Project, Midland and Glasscock Counties, Texas}

TEXAS ANTIQUITIES PERMIT NO. 8506

AUGUST 2018

PREPARED FOR

CrownQuest Operating, LLC

PREPARED BY

SWCA Environmental Consultants

Redacted 



\title{
CULTURAL RESOURCES INVESTIGATIONS FOR THE CROWNQUEST CITY OF MIDLAND OIL AND GAS PROJECT, MIDLAND AND GLASSCOCK COUNTIES, TEXAS
}

\author{
Prepared for \\ CrownQuest Operating, LLC \\ 18 Desta \\ Midland, Texas 79705 \\ Prepared by \\ Sophia Salgado, B.A. \\ Zachary Overfield, M.A., RPA \\ Cody Roush, B.A. \\ Principal Investigator \\ Zachary Overfield, M.A., RPA
}

\section{SWCA Environmental Consultants}

6200 UTSA Boulevard

Suite 102

San Antonio, Texas 78249

www.swca.com

Antiquities Code of Texas Permit No. 8506

SWCA Project No. 50853

SWCA Cultural Resources Report No. 18-560

August 2018 



\section{ABSTRACT}

SWCA Environmental Consultants (SWCA) was retained by CrownQuest Operating, LLC, to complete an intensive cultural resources investigation for the proposed CrownQuest City of Midland Oil and Gas Project (Project). The Project includes newly proposed oil and gas well pads, crude oil pipeline, and associated access roads on City of Midland property in Midland and Glasscock Counties, Texas. These new components will be constructed within an existing upstream oil and gas system. The 149.9-acre (60.7-hectare) Project area is located approximately 15 miles southeast of Midland, Texas, immediately south of Highway 158, and is situated along and between Johnson and Pemberton Draws.

The Project involves a political subdivision within the state of Texas (City of Midland). The Antiquities Code of Texas (ACT) applies because the Project's activities occur on property owned by the City of Midland and will involve more than 5 acres / 5,000 cubic yards of land disturbance or may potentially affect known archaeological sites. It is SWCA's understanding that the Project does not currently have a federal nexus, and it is not subject to Section 106 of the National Historic Preservation Act.

The purpose of this investigation was to identify and assess any cultural resources, such as historic and prehistoric archaeological sites and historic buildings, structures, objects, and sites (such as cemeteries) that might be located within the boundaries of the proposed Project and evaluate their significance and eligibility for designation as a State Antiquities Landmark. The investigations included a background and historic map review of the Project area and immediately surrounding region followed by pedestrian survey with visual examination and shovel test excavations at proposed Project activity areas. All investigations were conducted in accordance with the ACT and standards and guidelines established by the THC and Council of Texas Archeologists. Following the review and acceptance of the final cultural resources report, all records and photographs will be curated with the Center for Archaeological Research at the University of Texas at San Antonio, per requirements of the ACT in accordance with the CTA guidelines. The cultural resources investigation was conducted under ACT Permit No. 8506.

Fieldwork was performed from July 30 to August 4, 2018. The Project setting was mainly eroded and heavily disturbed uplands with occasional exposures of bedrock and caliche. Pedestrian survey was augmented by hand excavating 253 shovel tests and seven auger tests, which were terminated at the maximum reachable depth or at soils likely predating human occupation, typically around $45 \mathrm{~cm}$ below surface. The most pervasive land disturbance observed was related to petroleum exploration and extraction activities that have generally impacted ground surface integrity.

During the investigation SWCA archaeologists did not observe any prehistoric or historic cultural resources within the Project area. The location near site 41MD4, identified during the background review, could not be visited by SWCA survey staff due to a fire in the facility. The site boundary defined does not extend into a proposed Project activity area and the closest associated Project item is already disturbed. On that basis it is not considered to be a Project concern.

Based on the negative findings of the intensive cultural resources survey, SWCA recommends that no further archaeological investigations are warranted within the assessed portions of the CrownQuest City of Midland Oil and Gas Project area. 
Cultural Resources Investigations

for the CrownQuest City of Midland Oil and Gas Project

This page intentionally left blank. 


\section{CONTENTS}

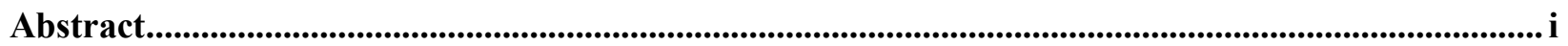

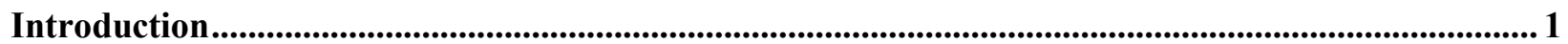

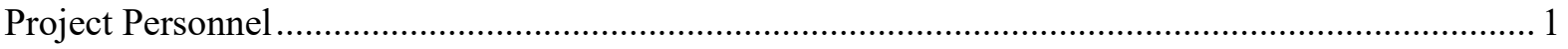

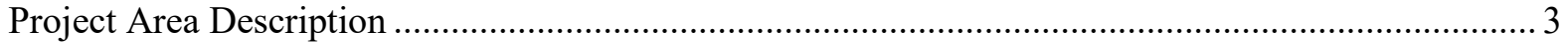

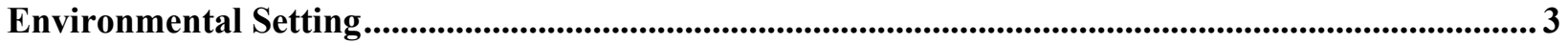

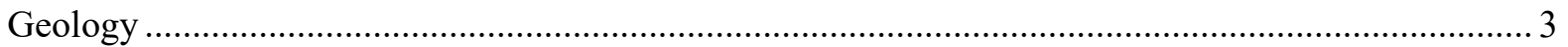

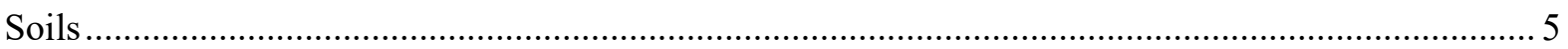

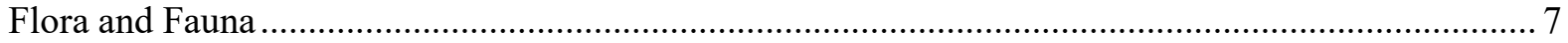

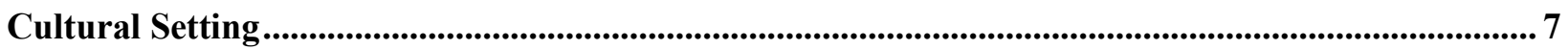

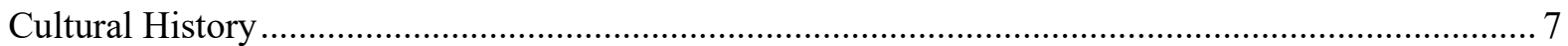

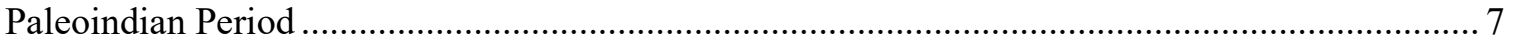

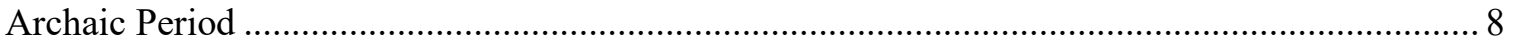

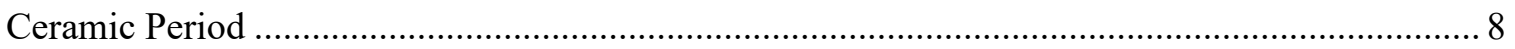

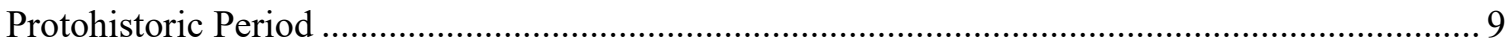

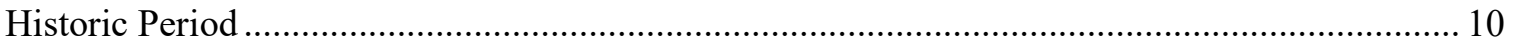

Background Research and Methods ...................................................................................................... 10

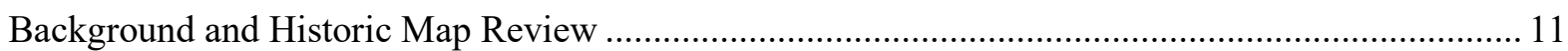

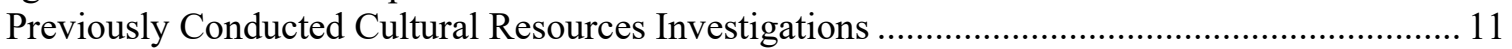

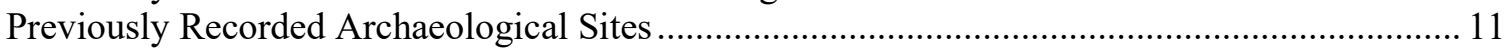

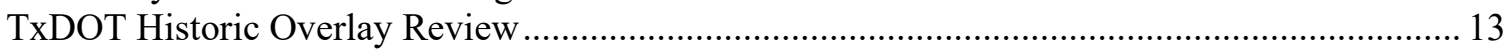

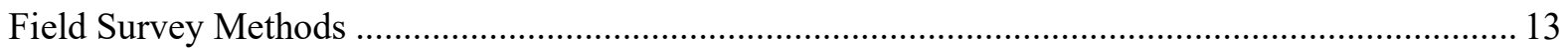

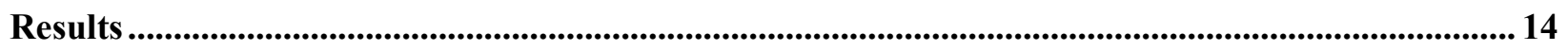

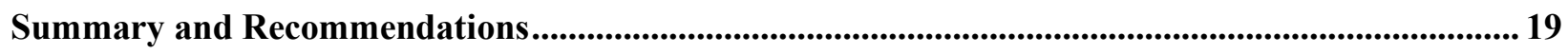

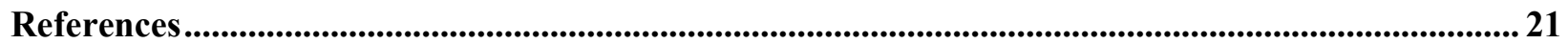

\section{Appendices}

Appendix A Survey Results Maps

Appendix B Shovel Test Results

Appendix C Auger test Results 


\section{Figures}

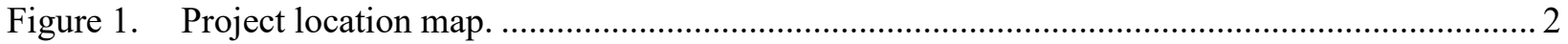

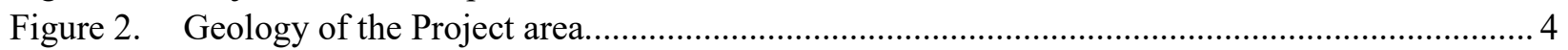

Figure 3. Soil map units crossed by the Project. ............................................................................ 6

Figure 4. Previously conducted cultural resources investigations and previously recorded sites

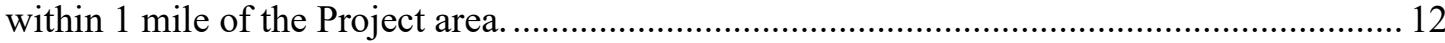

Figure 5. Overview of the southern terminus of Project area demonstrating completed

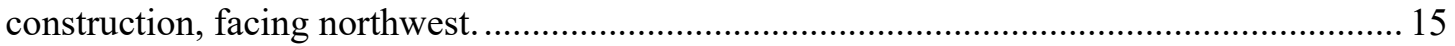

Figure 6. Overview of expansive oil and gas system landscape, facing west. .................................. 16

Figure 7. Overview of the northern terminus of Project area, facing north-northwest. ......................... 16

Figure 8. Typical shovel test profile observed in the eastern half of the Project area, terminated at

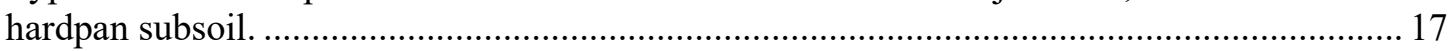

Figure 9. Typical shovel test profile observed in the western half of the Project area west, terminated at $1-\mathrm{m}$ below surface.

Figure 10. Overview of Auger03 test probe locale overlooking Pemberton Draw, facing northeast. ...... 18

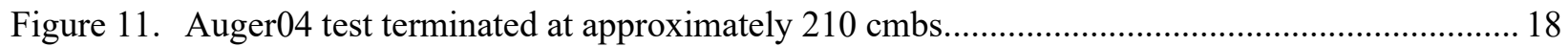

Figure 12. Overview of Project area crossing FM 1379, facing west toward site 41MD4.................... 19

\section{Tables}

Table 1. Geologic Units Traversed by the Project Area ....................................................................... 5

Table 2. Soil Associations within the Project Area............................................................................ 5

Table 3. Cultural Resource Investigations within 1 Mile of the Project Area ........................................ 13

Table 4. Known Cultural Resources within 300 Feet of the Project Area ............................................... 13 


\section{INTRODUCTION}

SWCA Environmental Consultants (SWCA) was retained by CrownQuest Operating, LLC (CrownQuest) to complete an intensive cultural resources investigation for the proposed CrownQuest City of Midland Oil and Gas Project (Project). The Project includes newly proposed oil and gas well pads, a crude oil pipeline, and associated access roads on City of Midland property in Midland and Glasscock Counties, Texas (Figure 1). These new components will be constructed within an existing upstream oil and gas system. The 149.9-acre (60.7-hectare [ha]) Project area is located approximately 15 miles southeast of Midland, Texas, immediately south of Highway 158, and is situated along and between Johnson and Pemberton Draws.

The Project involves a political subdivision within the State of Texas (City of Midland). The Antiquities Code of Texas (ACT) applies because the Project's activities occur on property owned by the City of Midland and will involve more than 5 acres $/ 5,000$ cubic yards of land disturbance or may potentially affect known archaeological sites. It is SWCA's understanding that the Project does not currently have a federal nexus, and it is not subject to Section 106 of the National Historic Preservation Act (NHPA). The ACT is administered by the Texas Historical Commission (THC), which also acts as the Texas State Historic Preservation Office.

Consistent with the ACT, the actions conducted under this permit were made in a reasonable and good faith effort to: 1) identify cultural resources within the Project area and 2) take into account any effects the Project activities could have on cultural resources sites that could be designated a State Antiquities Landmark (SAL).

The purpose of this investigation was to identify and assess any cultural resources, such as historic and prehistoric archaeological sites and historic buildings, structures, objects, and sites (such as cemeteries), that might be located within the boundaries of the proposed Project and evaluate their significance and eligibility for designation as a SAL. The investigations performed by SWCA included a background and historic map review of the Project area and immediately surrounding region, and pedestrian survey with visual examination and shovel test excavations at proposed Project activity areas. All investigations were conducted in accordance with the ACT and standards and guidelines established by the THC and the Council of Texas Archeologists (CTA). Following the review and acceptance of the final cultural resources report, all records and photographs will be curated with the Center for Archaeological Research at the University of Texas at San Antonio, per requirements of the ACT in accordance with the CTA guidelines. The cultural resources investigation was conducted under ACT Permit No. 8506.

\section{Project Personnel}

Zachary M. Overfield, M.A., RPA, served as Principal Investigator and Project Manager for the duration of the Project, overseeing overall logistics and organization, managing reporting, and agency consultation. Crew Lead Sophia Salgado, B.A., and Archaeologist Cody Roush, B.A., completed the survey from July 30 to August 3, 2018. Ms. Salgado, Mr. Roush, and Mr. Overfield prepared the report of investigations. Jason Kainer produced all field and report maps for the Project and Lauri Logan provided technical editing and document preparation. 


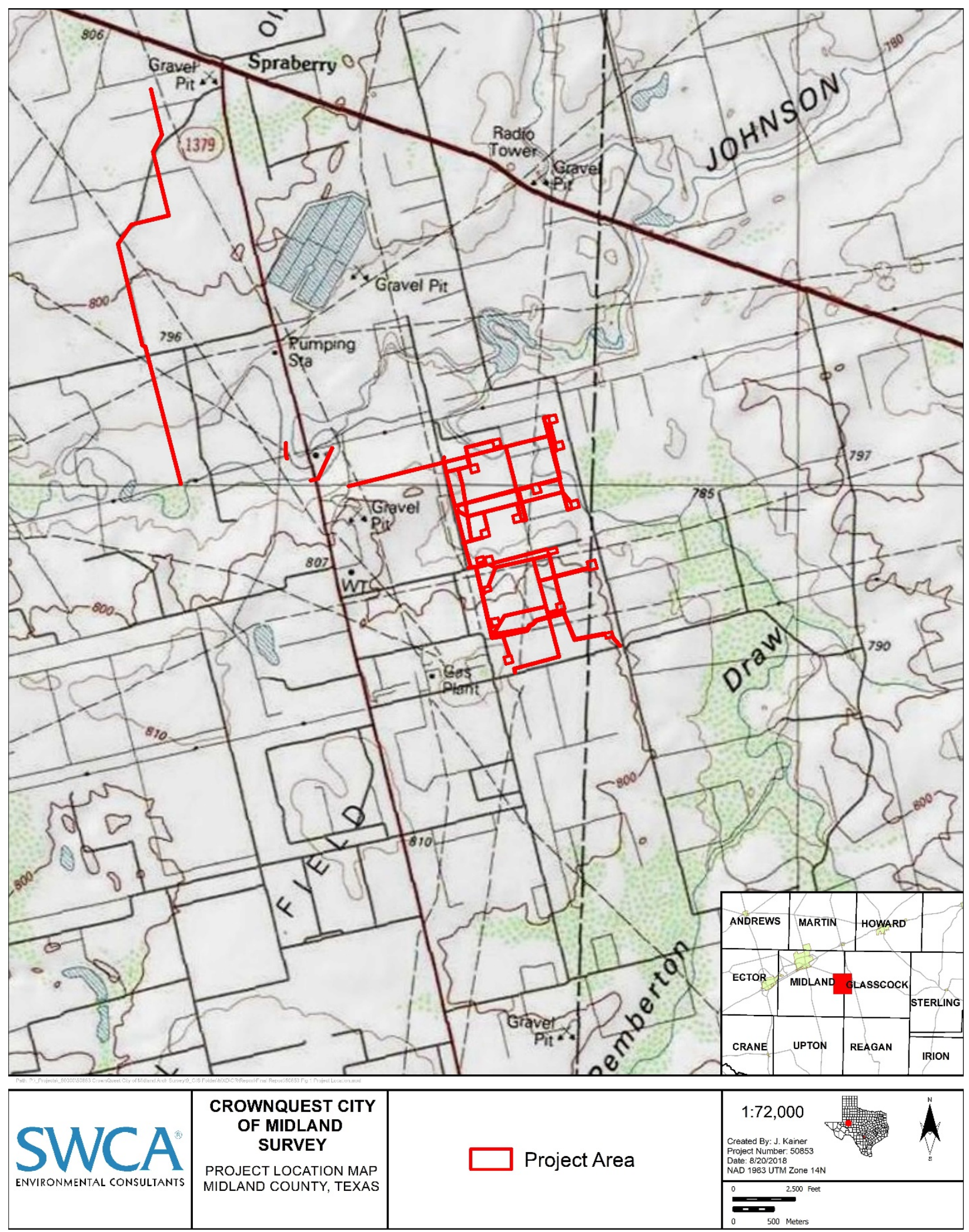

Figure 1. Project location map. 


\section{Project Area Description}

CrownQuest is proposing to install new pipeline and well pads for their Midland, Texas, oil and gas operations. The Project area is bounded by East County Road (CR) 230 to the south, Highway 158 to the north, South CR 1090 to the west, and a private road that intersects East CR 230 at its eastern terminus. The Project alignment traverses along the rights-of-way (ROWs) of South CR 1090, Farm-to-Market Road (FM) 1379, and numerous private roads within the extraterritorial jurisdiction of the City of Midland. Midland is located 13.3 miles (21.4 kilometers [km]) northwest of the western terminus of the Project alignment. The northwestern half of the Project area appears on Spraberry (3152.5-10145), while the southeastern half appears on a portion of the Pecks Lake (3145-10145) Texas U.S. Geological Survey (USGS) 7.5-minute topographic quadrangle maps (see Figure 1).

The Project area setting is predominately rural in nature with expansive agricultural fields and rangeland. Oil and gas infrastructure is located throughout the Project area. The northern terminus of the Project, which ends near Highway 158, intersects several extant well pads. The Project alignment crosses both Johnson and Pemberton Draws. CrownQuest currently proposes burying the line 48 inches as per the owner request. Several water bodies and streams, associated with Pecks Lake, are located just to the southwest of the Project area. The Project alignment is sparsely to moderately vegetated with grasses; shrubs; and scattered cottonwood, mesquite, oak, and hackberry trees; however, the majority has been cleared for pipeline and agricultural pursuits.

\section{ENVIRONMENTAL SETTING}

The Project area is situated within the High Plains Level III Ecoregion and the Arid Llano Estacado Level IV Ecoregion (Griffith et al. 2007). This ecoregion is drier than the main portion of the Llano Estacado to the north and contains more broken topography and fewer playas. Land use is predominantly livestock grazing and oil and gas production (Griffith et al. 2007).

\section{Geology}

The underlying geology of the Project area is mapped almost entirely as Windblown Cover Sand (Qcs) (Table 1, Figure 2). This formation was first documented in 1957 (Frye and Leonard 1957) and was described as fine- to medium-grained quartz, silty, calcareous, sand with caliche nodules. Frye and Leonard noted that there was a strongly developed soil formed at the surface of the cover sands. More recent research (see Holliday 1989 for a summary of this work) proposes renaming the formation to the Blackwater Draw Formation due to evidence indicating multiple periods of soil formation. The surface sediments in the Blackwater Draw formation likely predate human occupation (Holliday 1989).

Quaternary undivided deposits are situated in dissected areas intimately associated with Holocene-age alluvium and Pleistocene-age deposits. The deposits are composed of sand, clay, caliche, and gravel and may include older terrace remnants, lag gravels, residual soils, and colluvium commonly cemented by caliche (Eifler et al. 1994). Deposits of Holocene Alluvium have a good potential to contain intact buried cultural deposits.

The Antlers Sand formation (Ka) consists of sand, sandstone, siltstone, quartzite, and conglomerate of varying colors and is 25 to 100 feet thick (Eifler et al. 1994). The Antlers Sand formation is of Cretaceous-age. 


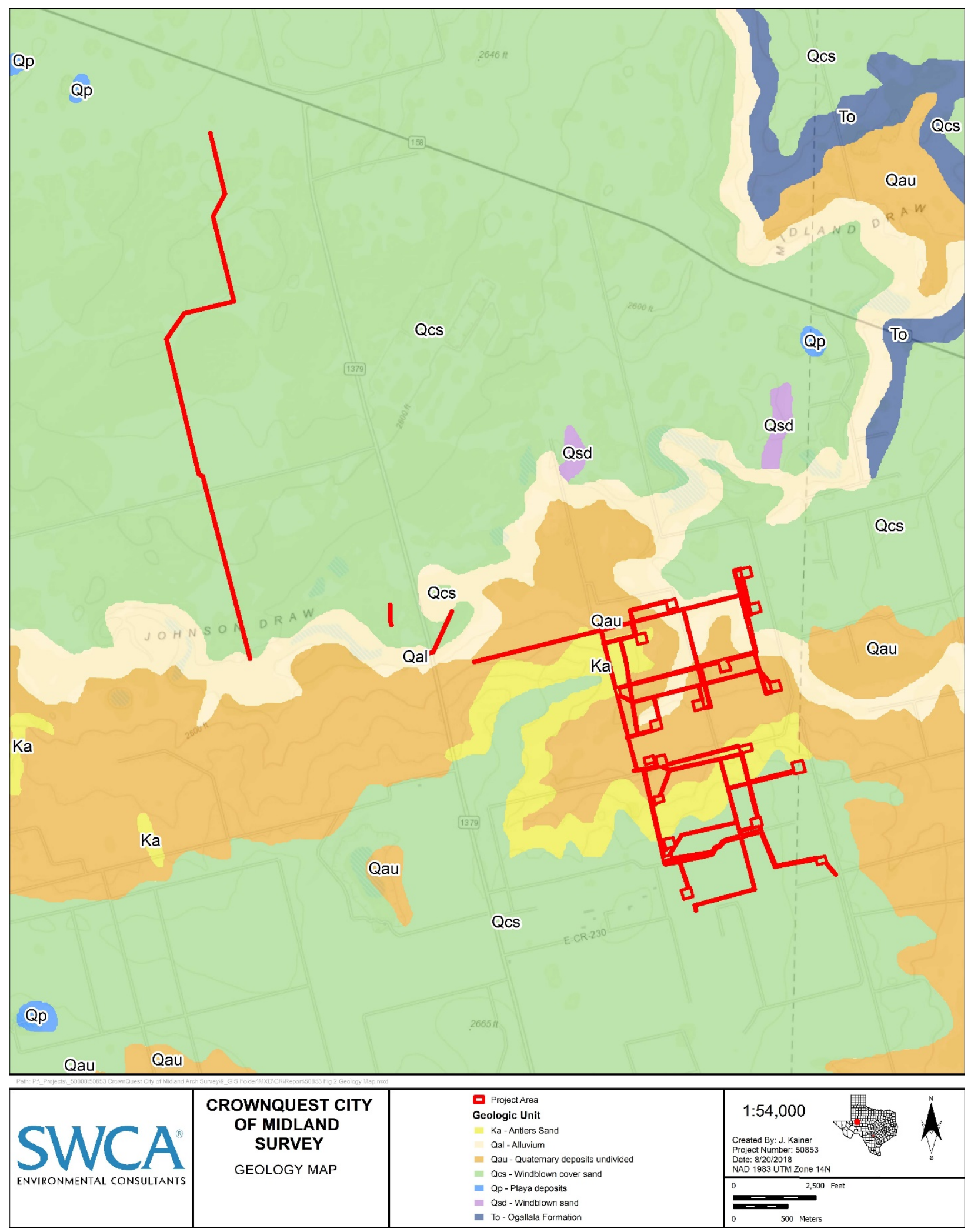

Figure 2. Geology of the Project area. 
Table 1. Geologic Units Traversed by the Project Area

\begin{tabular}{lllrr}
\hline Geologic Unit Name & Geologic Code & Age & Acreage & Percent \\
\hline Windblown Sand & Qcs & Pleistocene & 67.2 & $44.9 \%$ \\
\hline Quaternary Deposits, undivided & Qau & Holocene, Pleistocene & 50.1 & $33.4 \%$ \\
\hline Antlers Sand & Ka & Cretaceous & 16.5 & $11.1 \%$ \\
\hline Alluvium & Qal & Recent (Holocene) & 16.0 & $10.6 \%$ \\
\hline
\end{tabular}

\section{Soils}

According to the U.S. Department of Agriculture Natural Resources Conservation Service (2018), the Project area contains 10 mapped soil series units (Table 2; Figure 3). Most soil is mapped as either Reagan silty clay loam or Upton loam. Reagan silty clay loam consists of very deep, well-drained, moderately or moderately slowly permeable calcareous soils that formed in alluvium and/or eolian deposits derived from limestone to an average depth of 6.7 feet $(2.0 \mathrm{~m})$. Upton loam consists of shallow, well-drained, and moderately permeable soils that formed in gravelly, calcareous loamy slope alluvium and/or colluvium derived from limestone and marl to an average depth of 6.7 feet $(2.0 \mathrm{~m})$. Table 2 lists all soil units that occur within the Project area.

Table 2. Soil Associations within the Project Area

\begin{tabular}{llrr}
\hline Soil Type & Symbol & Acreage & Percent \\
\hline Reagan silty clay loam, 0 to 1 percent slopes & ReA & 35.7 & $23.8 \%$ \\
\hline Upton loam, 1 to 3 percent slopes & UpB & 34.2 & $22.8 \%$ \\
\hline Slaughter clay loam, 0 to 1 percent slopes & ScA, SIA & 25.7 & $17.2 \%$ \\
\hline Bippus clay loam & Bc & 17.5 & $11.7 \%$ \\
\hline Springer loamy fine sand, 0 to 3 percent slopes & SpB & 11.6 & $7.7 \%$ \\
\hline Midessa fine sandy loam, 1 to 3 percent slopes & MdB & 11.3 & $7.5 \%$ \\
\hline Amarillo fine sandy loam, 0 to 3 percent slopes & AfA, AfB & 6.4 & $4.3 \%$ \\
\hline Kimbrough loam & Kb & 4.8 & $3.2 \%$ \\
\hline Conger clay loam, 1 to 5 percent slopes & CnC & 2.6 & $1.8 \%$ \\
\hline Lipan clay, 0 to 1 percent slopes, frequently ponded & Lp & $<0.1$ & $<0.1 \%$ \\
\hline
\end{tabular}




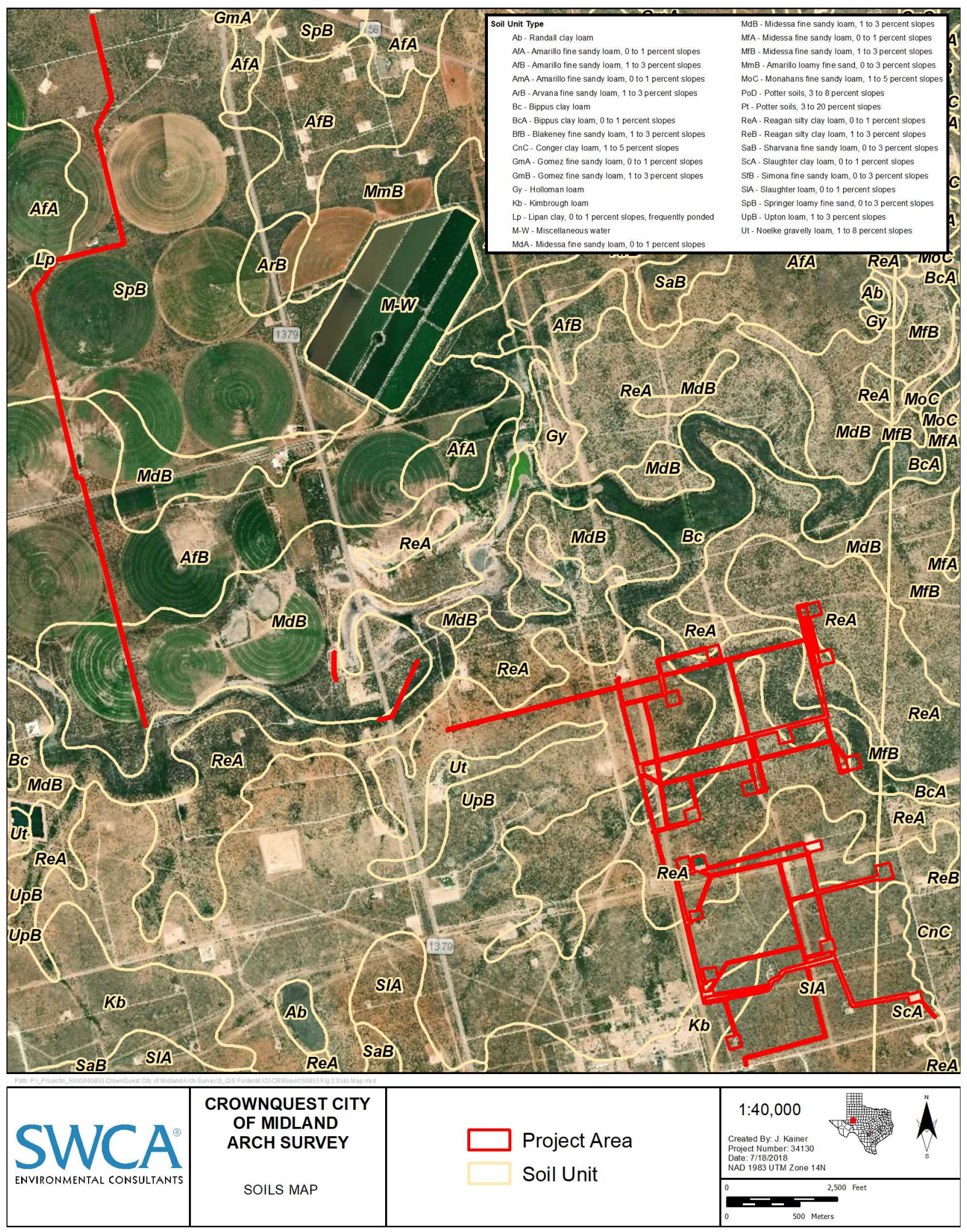

Figure 3. Soil map units crossed by the Project. 


\section{Flora and Fauna}

The Project area falls within the Kansan and Texas biotic provinces (Blair 1950). The former covers the Plains regions north to the Red River and throughout the Texas panhandle. The latter covers the central Texas Edwards Plateau. These areas include various short-grass species including buffalo grass (Bouteloua dactyloides) and grama grass (Bouteloua spp.). Mesquite (Prosopis juliflora), juniper (Juniperus sp.), and shin oak (Quercus havardii) are all common tree species in the area.

Common mammals of the Project area include white-tailed deer (Odocoileus virginianus), opossum (Didelphis virginiana), raccoon (Procyon lotor), nine-banded armadillo (Dasypus novemcinctus), blacktailed jackrabbit (Lepus californicus), and deer mouse (Peromyscus maniculatis). Less common are the predatory mammals including bobcat (Lynx rufus), coyote (Canis latrans), and gray fox (Urocyon cinereoargenteus). In addition to these common mammals, bison (Bison bison), mountain lion (Felis concolor), and black bear (Ursus americanus) occurred historically (Blair 1950).

\section{CULTURAL SETTING}

\section{Cultural History}

Geographically the Project area lies on the Southern High Plains and Central Texas margin, although many regional overviews include it within the Plains cultural region. Hofman (1989) and Johnson and Holliday (1995) have summarized the cultural history of the Southern High Plains. Collins (1995) has synthesized the Central Texas chronology. Other useful summaries include Boyd's (1995) synopsis of the Palo Duro Complex of the Caprock Canyonlands, north of Midland, the historic archaeology discussion presented by Hays et al. (1989), and Hays's (1989) historic tribal group summary. This cultural history draws on those studies and other reports, including Johnson and Holliday (1995) who divide the cultural history of the region into five periods: Paleoindian (11,500-8500 B.P.), Archaic (8500-2000 B.P.), Ceramic (2000 B.P. to ca A.D. 1450), Protohistoric (ca. A.D. 1450-1650), and Historic (ca. A.D. 1650 1950).

\section{Paleoindian Period}

As with other parts of the state, the earliest irrefutable evidence of human occupation is circa 11,500 11,000 B.P. at several sites where the inhabitants left behind Clovis points, the earliest projectile points known to be found in North America. The projectile point type and the culture derive their names from the Clovis site in eastern New Mexico, near the western edge of the Southern High Plains (Holliday 1997). Other Clovis sites with good stratigraphic contexts are found in draws, playas, and dunes in the Southern High Plains (Holliday 1997:50).

The early Paleoindian period climate at the close of the Pleistocene was cooler and more humid in the region than it is today (Johnson and Holliday 1995:522). The remains of butchered megafauna have been found at several Clovis sites, indicating that big-game hunting was an important part of the subsistence pattern for early Paleoindians. Site 41TA148, known as the Yellow Hawk Site, is the closest Clovis site to the Project area (100 miles [160.9 km] east of the Project area), and the material from the site, which has not been intensively investigated, suggests Paleoindians were hunting on the uplands of the Callahan Divide along the southern edge of the Great Plains to the north.

Hofman (1989:25) echoes the speculation of Kelly and Todd (1988) that the earliest peoples in the area may have been oriented on species migrations rather than place oriented, an economy that probably 
resulted in a high degree of group mobility. Big-game hunting continued to be an important activity even as the climate became warmer and drier, and the style of projectile point changed from Clovis to Folsom $(10,800-10,300$ B.P.) and then from Folsom to Plainview (ca. 10,000 B.P.). At the Plainview site, well north of the Project area, at least two large-scale bison kills were evident in the archaeological record. Over 100 animals were killed at the site. One event took place in spring, and the other in early fall (Johnson and Holliday 1995:524).

By the end of the Paleoindian period, the Firstview (ca. 8600 B.P.) projectile point had replaced Plainview, and the Early Holocene warming and drying trend had taken firm hold of the region (Johnson and Holliday 1995:525). From the handful of Firstview sites in the area, it is clear that bison hunting was still an important activity, but other Paleoindian lifeways may have been changing. The increased temperatures were accompanied by increased seasonality, and summer droughts brought about disappearing surface water and a change in vegetation patterns. Some parts of the region may have begun to change from short-grass prairie to scrub-grasslands, and alkaline marshes began to form in the floors of draws and small valleys (Johnson and Holliday 1995:525).

\section{Archaic Period}

Although the archaeological record for the first part of the Archaic period is poorly documented, data are available concerning the Central Texas and Southern High Plains changing environment. The warming and drying trend that began near the end of the Pleistocene continued to intensify with the result that aeolian sedimentation in the area "was episodic but widespread from 9000 until 5500 B.P." (Johnson and Holliday 1995:526). Lubbock Lake is one of the few excavated Early Archaic sites in the region; data from there suggest that the inhabitants of the area were still hunting and butchering small herds of bison, but little else is known about their activities (Johnson and Holliday 1995).

The drying trend peaked during what is known as the Altithermal, ca. 6500-4500 B.P. This coincides with the Middle Archaic, a cultural period represented by a handful of Southern High Plains sites (Johnson and Holliday 1995). At three sites, Middle Archaic occupants excavated wells to cope with the dry conditions. If Lubbock Lake is typical of the Middle Archaic, then relatively intensive occupation existed despite the harsh conditions. Excavations there uncovered nearly 30 activity areas representing camping areas, bison kill or butchering locations, and a large rock oven (Johnson and Holliday 1995:527).

As the climate returned to cooler and moister conditions, the landscape became more stable. Sedimentation decreased and wind erosion diminished as the desert-plains grassland of the Middle Archaic gave way to mixed grass prairies (Johnson and Holliday 1995:528). Although the area would have been more favorable for human habitation, the current dearth of stratified Late Archaic sites limits our understanding in the area. Late Archaic campsites, rockshelters, bison kill sites, and lithic procurement sites are all known from the Southern High Plains, but stratified sites are rare (Johnson and Holliday 1995:528). Late Archaic point types have been documented at 41HW1, the Big Spring site, but their context is not well documented since non-archaeologists collected them (THC 2018).

\section{Ceramic Period}

Near the end of the Archaic period, ca. 2000 B.P., some data suggest a pattern of episodic droughts began that continues to the present. Bison hunting was an important activity —at least at Lubbock Lake (Johnson and Holliday 1995). Other researchers (e.g., Boyd 1995:461; Dillehay 1974:187), however, believe that it may have actually been wetter at the beginning of the Ceramic period than at the close of the Archaic. In general, conditions may have been less favorable for bison, and a "general decline in the number of bison in the Southern Plains may have occurred around 1500 B.P., and populations probably remained relatively low until around 800 B.P." (Boyd 1995:461). 
Groups in the Southern High Plains began using not only ceramics but the bow and arrow as well; both were new technologies that marked significant cultural changes (Johnson and Holliday 1995). These new technologies arrived in the Southern High Plains, in part, from trading or migration patterns moving westward from Woodland period peoples and eastward from Puebloan peoples - both ceramic-using groups who practiced agriculture and lived in semi-permanent villages (Boyd 1995:461). The Caprock Canyonlands northeast of Midland were the focus of important interactions between these two groups during the Ceramic period (Boyd 1995).

The area around Midland may have been outside this range. The nearest well-defined ceramic-using complex is Palo Duro, located northwest of Taylor County in the Red River's Prairie Dog Town Fork escarpment and the Double Mountain Fork of the Brazos River (Boyd 1995:501). As Boyd (1995:503) notes, "there are not sufficient archaeological data to indicate whether the upper Colorado River... was or was not occupied by Palo Duro peoples."

Boyd's (1995:482) Palo Duro complex definition suggests that attributes of the complex may have appeared as early as B.P. 2000-1500, but were definitely "recognizable" by B.P. 1500. Palo Duro occupations were contemporaneous with the Plains Woodlands occupations in the northern Texas Panhandle, and lasted until B.P. 900, when they seem to have disappeared quite suddenly.

Campsites, residential villages, and rockshelters typify most excavated Palo Duro sites, but human burials have also been documented (Boyd 1995:467). The residential villages include pithouses where people lived and possibly practiced limited horticulture. The settlement patterns, types of sites, and artifact assemblages suggest that the culture was semisedentary, maintaining a "high degree of residential mobility...to exploit a wide range of resources that were locally available and abundant on a seasonal basis" (Boyd 1995:508).

\section{Protohistoric Period}

The Protohistoric period technically begins with Coronado's first Spanish entrada into the Southern Plains in 1541 (Hofman 1989:91). Francisco Vásquez de Coronado entered the Southern Plains from New Mexico in 1541 in search of the Seven Cities of Cíbola. He possibly passed east of Midland (Donoghue 2003). According to an historical marker located approximately 100 miles east of the Project area at the intersection of FM 89 and US 277:

In 1541, the Spanish explorer Coronado is thought to have passed this way en route from New Mexico to the fabled Indian villages of "Quivira", though his path across vast Texas plains is now difficult to determine. Upon finding that his Indian guide, "The Turk," had taken him too far south, Coronado halted at a small canyon or barranca. Here he conferred with his captains and decided to follow the compass directly north. When they reached "Quivira" (possibly in Kansas), no gold was found - only the poor, grass huts of a Wichita village (Historical Marker 2626, erected in 1968)

Spanish contact with local Native Americans was sporadic and the next well-documented visit to the area was not until 1632. Fray Juan de Salas and Father Juan de Ortega passed through the region, stopping near San Angelo to work with some Jumano Indians (Blake 2003).

Although numerous Protohistoric sites are known in the region, few have good stratigraphic context (Johnson and Holliday 1995:530). Most are north of Midland around Lubbock Lake and in Garza County (Hofman 1989); however, metal points from 41HW1 may indicate a Protohistoric occupation, and a significant Late Prehistoric site with a possible Protohistoric component is in northern Sterling County. Site 41ST87 was excavated by avocational archaeologists for nearly a decade, and many of the materials 
recovered have been analyzed and classified by members of the Concho Valley Archaeological Society (Jim Davis, personal communication 2003). The site has yielded material spanning the Archaic through Protohistoric periods, with the 1992 site form stating hundreds of dart points, over 1,000 arrow points, over 1,000 ceramic sherds and a few historic artifacts - a link of chainmail, a metal arrow point, blue trade beads, and lead slugs (TARL, 41ST87 site form). Whether the historic artifacts represent direct contact between the site occupants and early Spanish explorers is not clear but possible.

The Protohistoric occupations at sites in the Southern Great Plains typically have Garza points and a high frequency of Southwestern sherds (Hofman 1989). Occasionally, other artifacts of Southwestern origin appear in the Protohistoric, including obsidian, turquoise, and Olivella beads (Hofman 1989:99).

Some major cultural events occurred during the Protohistoric that resulted in permanent changes to the Native American cultures in the Southern Great Plains. Apache groups occupied the region for most of the period, with the Comanches displacing them near the beginning of the Historic period (Campbell 1983). These groups witnessed the introduction of the horse, which greatly changed many aspects of Native American life; the spread of European diseases, which decimated the indigenous populations; and the interaction between "both Native American hunting societies and horticulturalists" and Spanish and Anglo-American economic spheres through trading (Hofman 1989:99).

\section{Historic Period}

By the beginning of the Historic period, the Comanche had moved into the Project area, displacing the Apache to the south and west (Campbell 1983; Hays 1989). In 1787, Juan de Ugalde led an extensive expedition through the region, passing probably west of the survey area in an effort to subdue the displaced Apaches.

Ugalde's expedition was part of a new Spanish policy for securing the northern frontier: use the threat of military force and an offer of protection from the Comanche as an inducement for peace. The policy was brutal and ultimately ineffective, and both the Comanche and Apache continued to dominate the area well into the middle of the following century.

One main Comanche trail originated in Mexico and merged with another trail near what is today Fort Stockton (Comanche Springs prior to 1859). It passed through the region, probably southeast of Midland (Holden 2003; Sheffield 2001).

The presence of Comanche groups in the area delayed Anglos from settling in the Southern Plains until the latter half of the nineteenth century, with the exception of military camps and stagecoach stops (Hays et al. 1989). Early civilian settlement in the region primarily concentrated on areas along and east of the spring, including a 'tent city' that rapidly grew near the spring to cater to travelers along the trail. When the railroad scheduled their route to run through Midland, to the north of the Project area, the settlement moved north.

\section{BACKGROUND RESEARCH AND METHODS}

SWCA conducted cultural resources investigations to identify and assess their significance within the Project area. Significance, as indicated and in accordance with the National Register of Historic Places (NRHP) criteria under 36 Code of Federal Regulations (CFR) 60.4 (Criteria A-D), is determined by the property's: (A) potential to contribute to the further understanding of broad patterns of American history, (B) association with a significant person, (C) design or construction, or (D) information potential. Additionally, other factors affecting this determination include integrity, chronology, and preservation 
potential. Particular emphasis is given to exploring sites that could yield data to complement previous investigation in the area and provide new information.

The investigations conducted for the Project included a background and historic map review, and an intensive pedestrian survey with shovel and auger test excavations. All investigations were conducted in accordance with the guidelines provided in Section 106 of the NHPA (National Park Service 1983), as well as with the THC and CTA standards. The supervising cultural resources personnel meet or exceed the U.S. Secretary of the Interior's Professional Qualifications Standards (36 CFR 61).

\section{Background and Historic Map Review}

SWCA performed a cultural resources background review on June 4, 2018, to determine if the Project area has been previously surveyed for cultural resources or if any cultural resources have been recorded within or near the Project area. To conduct this review, an SWCA archaeologist reviewed the relevant USGS 7.5-minute topographic quadrangle maps on the THC's Texas Archeological Sites Atlas (Atlas). These sources provided information on the nature and location of previously conducted archaeological surveys, previously recorded cultural resources sites, locations of NRHP districts and properties, sites designated as SALs, Official Texas Historical Markers, Recorded Texas Historic Landmarks, cemeteries, and local neighborhood surveys. As a part of the review, an SWCA archaeologist also reviewed the Texas Department of Transportation (TxDOT) Historic Overlay, a mapping/GIS system with historic maps and resource information covering most portions of the state.

Previous cultural resources investigations listed on the Atlas are limited to projects under purview of the ACT or the NHPA. Therefore, the Atlas does not necessarily list all previous work conducted within a specific area. In addition, projects may not be posted to the Atlas until both field work and reporting are complete.

\section{Previously Conducted Cultural Resources Investigations}

The background review determined that no previous cultural resources investigations intersect the Project area (Figure 4, Table 3) although one investigation was conducted within 1 mile of the Project Area. In 2012, a linear survey was conducted by Pritchett Engineering \& Planning, LLC, on behalf of the Federal Energy Regulatory Commission (FERC). No additional information for this survey was available on the Atlas.

\section{Previously Recorded Archaeological Sites}

The background review found one previously recorded archaeological site (41MD4), adjacent to the Project area boundary (Table 4; see Figure 4). Site 41MD4 is located 300 feet west of the Project gathering line and is an Archaic-period open campsite consisting of a surficial lithic artifact scatter and fire-cracked rock. This site was originally documented in 1975 for the Johnson Draw Reservoir Project. No recommendations regarding its potential significance or for further work were made at that time. 


\title{
Restricted Information
}

\author{
Not for Public Disclosure
}

Figure 4. Previously conducted cultural resources investigations and previously recorded sites within 1 mile of the Project area. 
Table 3. Cultural Resource Investigations within 1 Mile of the Project Area

\begin{tabular}{|c|c|c|c|c|c|}
\hline $\begin{array}{l}\text { Year of } \\
\text { Investigation }\end{array}$ & $\begin{array}{l}\text { Investigation } \\
\text { Type }\end{array}$ & Project & $\begin{array}{l}\text { Sponsoring } \\
\text { Agency/Author }\end{array}$ & $\begin{array}{l}\text { ACT } \\
\text { Permit } \\
\text { No. }\end{array}$ & Investigation Summary/Results \\
\hline 2012 & Survey & - & $\begin{array}{l}\text { Federal Energy } \\
\text { Regulatory } \\
\text { Commission/ } \\
\text { Carter-Davis et al. }\end{array}$ & - & $\begin{array}{l}\text { Linear survey } 0.6 \text { mile }(1.0 \mathrm{~km}) \text { south of the Project } \\
\text { area along a two-track road. No archaeological } \\
\text { sites were recorded within Project boundary. No } \\
\text { additional information available on the Atlas (THC } \\
2018) \text {. }\end{array}$ \\
\hline
\end{tabular}

Table 4. Known Cultural Resources within 300 Feet of the Project Area

\begin{tabular}{lll}
\hline Site & Site Type & Description \\
\hline 41MD4 & Prehistoric Open Campsite & $\begin{array}{l}300 \text { feet }(91.4 \mathrm{~m}) \text { west of gathering line. Archaic open campsite. Cultural assemblage } \\
\text { includes a surficial lithic artifact scatter and burned rock. Site partially covered by sand. } \\
\end{array}$ \\
& $\begin{array}{l}\text { Depth of deposit unknown. Site recorded in 1975 for the Johnson Draw Reservoir } \\
\text { Project. No recommendations for further work made (THC 2018). }\end{array}$ \\
\hline
\end{tabular}

\section{TxDOT Historic Overlay Review}

TxDOT historic overlay maps dating from 1954 to 1965 display dozens of potential historic-age structures associated with petroleum production and infrastructure within the review area (Foster et al. 2006). These structures are depicted on the 1954 San Angelo, Texas and 1965 Pecks Lake USGS maps (Foster et al. 2006; USGS 2018). The maps do not identify any confirmed historic cultural resource sites or other properties of interest within or immediately adjacent to the Project area.

\section{Field Survey Methods}

SWCA's field investigations consisted of an intensive pedestrian survey with subsurface investigations within the Project area. Archaeologists examined the ground surface and substantial exposures for cultural resources. Subsurface investigations consisted of systematic shovel test excavations and hand-operated bucket augering at select locations. For linear project areas, the THC survey standards minimally require 16 shovel tests per mile with transects spaced at 98.4-foot (30-m) intervals. A project of this length (totaling approximately 9 miles [14.5 km]) requires a minimum of 144 shovel tests. SWCA exceeded the minimum requirement by excavating 253 shovel tests and seven auger tests.

SWCA archaeologists employ both metric (centimeters and meters) and English (inches and feet) units of measurement when conducting investigations within a project area. In compliance with archaeological standard practices, investigations such as shovel tests, auger tests, and backhoe trenches are recorded using metric units. Prehistoric archaeological resources, such as campsites, features, and artifacts, are also recorded using metric units, whereas historic resources, such as farmsteads and associated historic features, are recorded using English units. No conversions for these measurements is provided in the field data collected.

SWCA primarily utilized systematic shovel testing throughout the entire Project area and used a handoperated bucket auger at select locations near the banks of Pemberton and Johnson Draws. Shovel testing intervals depended on the level of previous land disturbances, construction, and soil characteristics. SWCA did not conduct shovel testing in areas where impervious substrates (i.e., asphalt, concrete, 
compact gravel, and/or caliche) were present, within $5 \mathrm{~m}$ of any paved/graveled road edges, within $5 \mathrm{~m}$ of any identified/marked buried utility markers, or where evidence of extensive ground surface disturbance was observed. Shovel tests were excavated in approximately 20-centimeter $(\mathrm{cm})$ arbitrary levels to culturally sterile deposits or compact soils, whichever came first.

Archaeologists screened the matrix through $1 / 4$-inch mesh. The location of each shovel test was plotted using a hand-held, sub-meter accurate global positioning system (GPS) receiver and was recorded on appropriate project forms in SWCA's field tablets. SWCA conducted a non-collection survey; artifacts encountered were tabulated, analyzed, and documented in the field, but not collected. Following the review and acceptance of the final cultural resources report, all records and photographs will be curated with the Center for Archaeological Research at the University of Texas at San Antonio, per requirements of the ACT in accordance with the CTA guidelines.

In the unlikely event that unanticipated cultural materials are encountered during subsequent construction activities, CrownQuest or their designated representative will immediately cease work within 100 feet $(30.5 \mathrm{~m})$ of the discovery. CrownQuest or their designated representative, should immediately notify THC. Work in the affected area could only resume per THC authorization.

\section{RESULTS}

The intensive pedestrian survey supplemented with shovel and auger test excavations was conducted by SWCA archaeologists from July 30 to August 4, 2018. The Project area is located in the dissected upland plains southeast of Midland, Texas, on city-owned land with an abundance of existing oil and gas production facilities and infrastructure.

SWCA's investigation concentrated on the proposed Project oil and gas well pads, crude oil pipeline corridors, and associated access roads for cultural resources (Appendix A). The survey began at the southern end of the Project alignment. Field personnel then worked north along the Project area. SWCA archaeologists visually examined the eastern half which consists of an existing upstream oil and gas system. Investigators photo-documented the existing infrastructure within this Project area (Figure 5). The western half is predominately situated in an agricultural and rangeland setting, juxtaposed with oil pumps, tanks and fracking wells (Figures 6 and 7). Vegetation within this Project area consists of mesquite, cacti, scrub and underbrush, and short to medium bunched grasses. SWCA archaeologists excavated shovel tests at 328-foot (100-m) intervals. The typical size of a proposed well pad averaged 2 acres $(0.81 \mathrm{ha})$, where a minimum of four shovel tests were excavated.

The most prevalent forms of disturbance observed within the Project area includes petroleum activities (e.g., oil extraction and transmission), pipelines, erosion, vegetation clearing, fence lines, and access road construction.

SWCA archaeologists excavated a total of 253 shovel tests and seven auger tests. Sparse to moderate vegetation dominated the landscape with bedrock or heavy caliche inclusion occurring on the surface or at very shallow depths to the east of FM 1379 and loose sand terminated at 1-m deep in the western half of the Project area (Figures 8 and 9). Field personnel observed ground surface visibility to be greater than 50 percent across the entirety of the Project area. Most shovel tests in the Project area were excavated to approximately $40 \mathrm{~cm}$ below surface $(\mathrm{cmbs})$ before reaching a hardpan sandy clay, bedrock, or impenetrable gravel (Appendix B). The shallow soils encountered were typically a yellowish brown to brown (7.5YR 5/4 to 7.5 YR 4/3) sandy loam. Deep soils, when present, were typically a brown to a yellowish red (7.5YR 4/4 to 5 YR 5/6), loose sand. The auger test probes were excavated on the banks of Johnson and Pemberton Draws at their intersection with the Project easement. The maximum depth reached was $210 \mathrm{cmbs}$, with all 
seven auger tests terminating at bedrock or heavily compact subsoil (Figures 10 and 11). All seven auger tests resulted in negative findings with no evidence of artifacts or buried soil horizons.

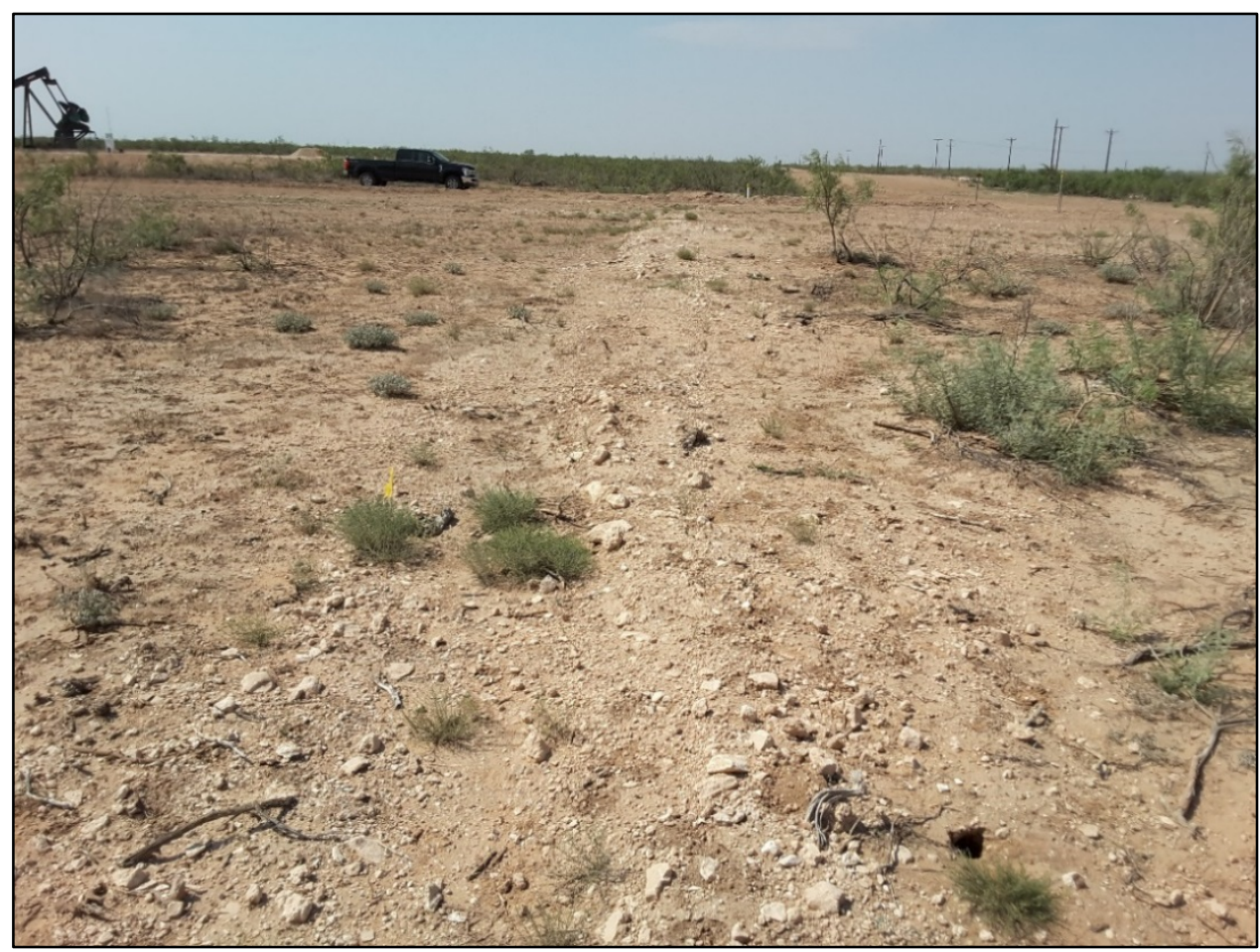

Figure 5. Overview of the southern terminus of Project area demonstrating completed construction, facing northwest. 


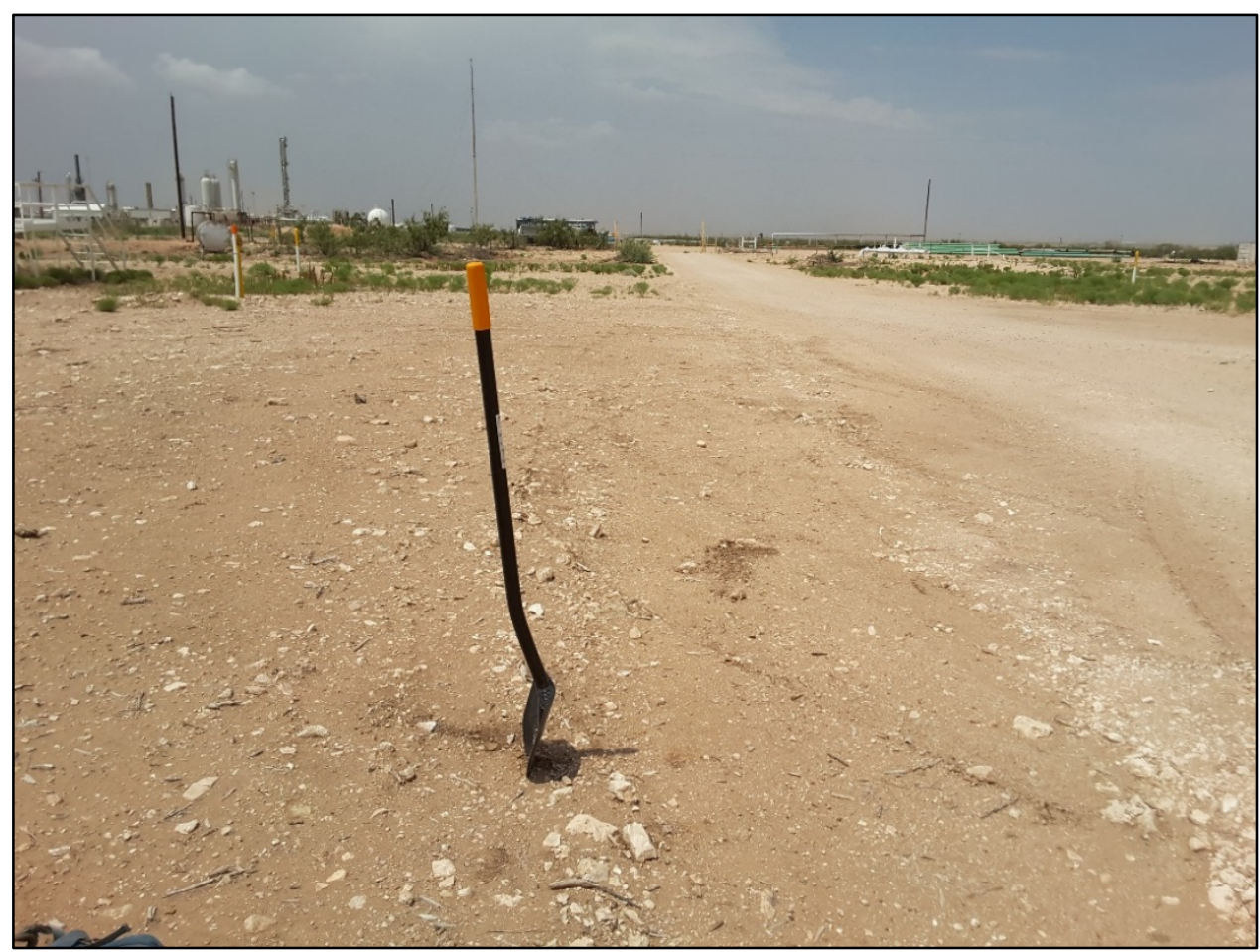

Figure 6. Overview of expansive oil and gas system landscape, facing west.

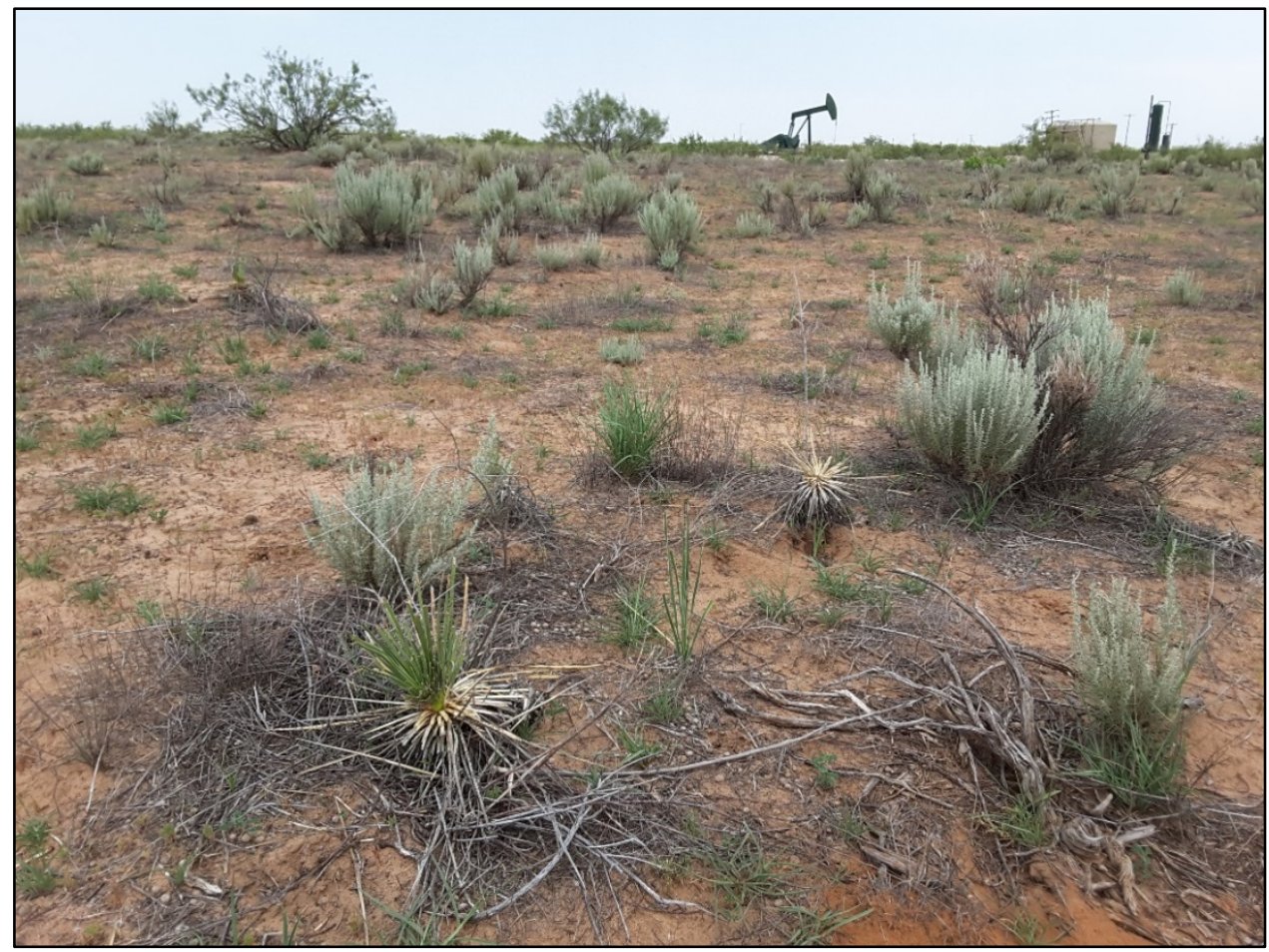

Figure 7. Overview of the northern terminus of Project area, facing northnorthwest. 


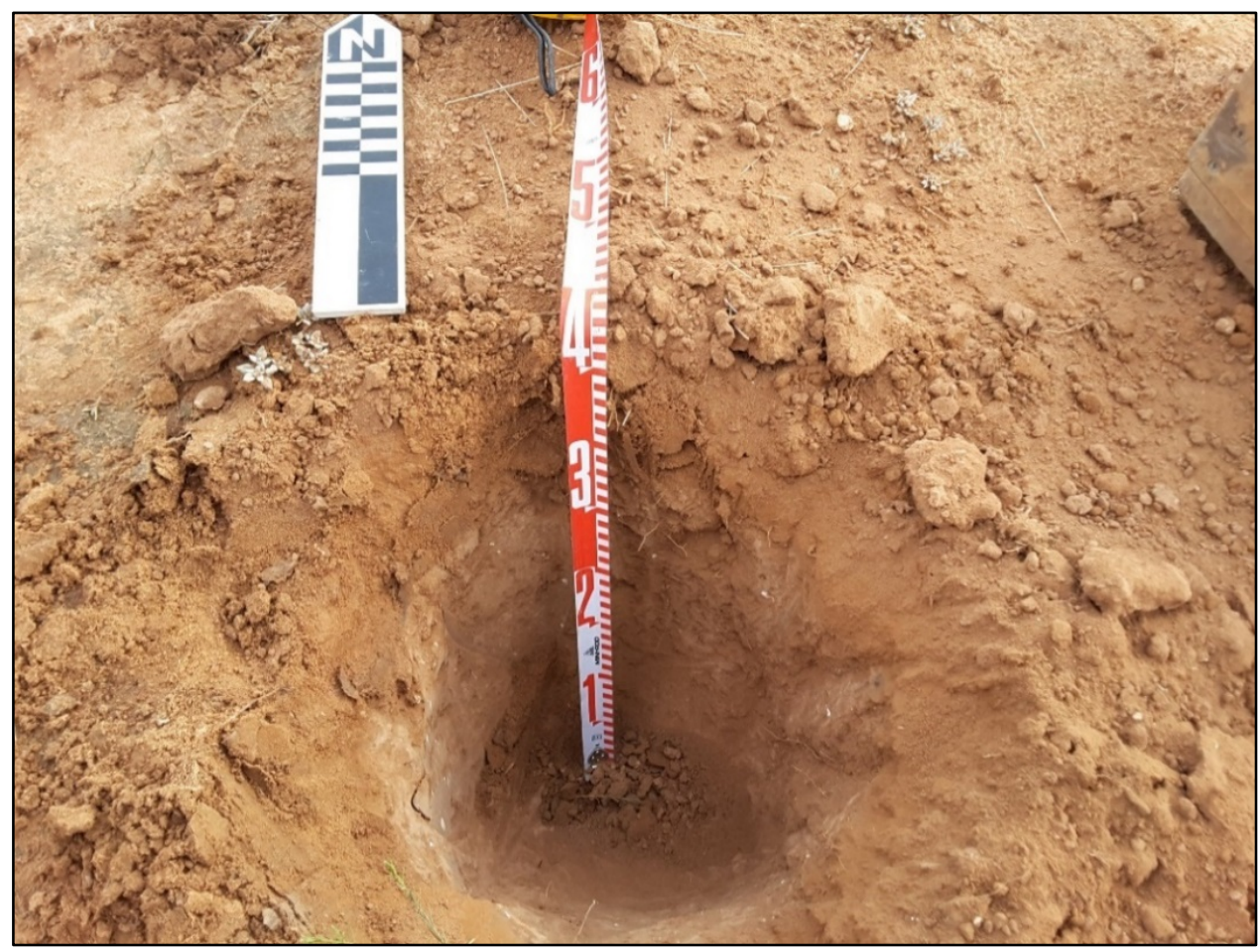

Figure 8. Typical shovel test profile observed in the eastern half of the Project area, terminated at hardpan subsoil.

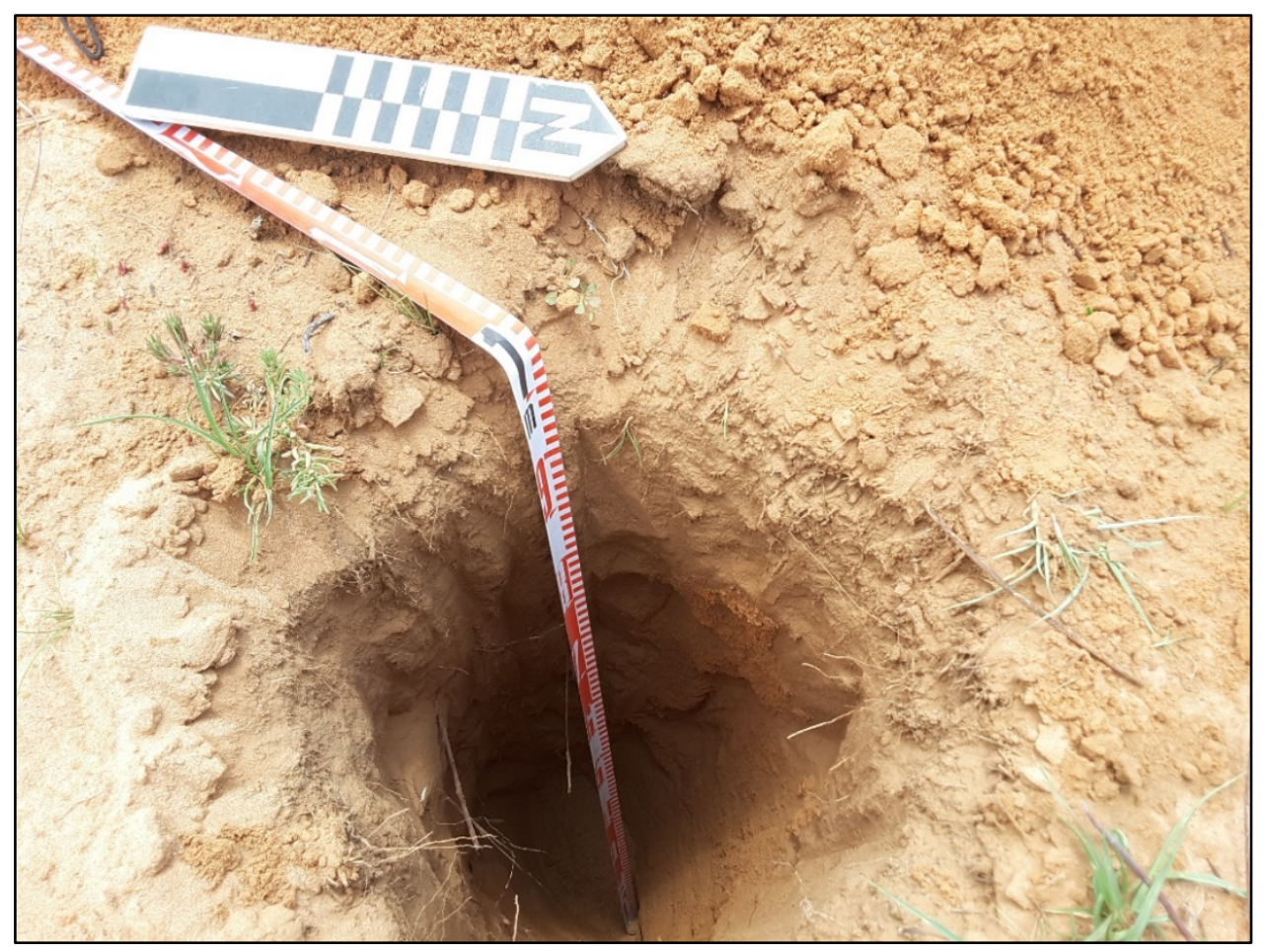

Figure 9. Typical shovel test profile observed in the western half of the Project area west, terminated at 1-m below surface. 


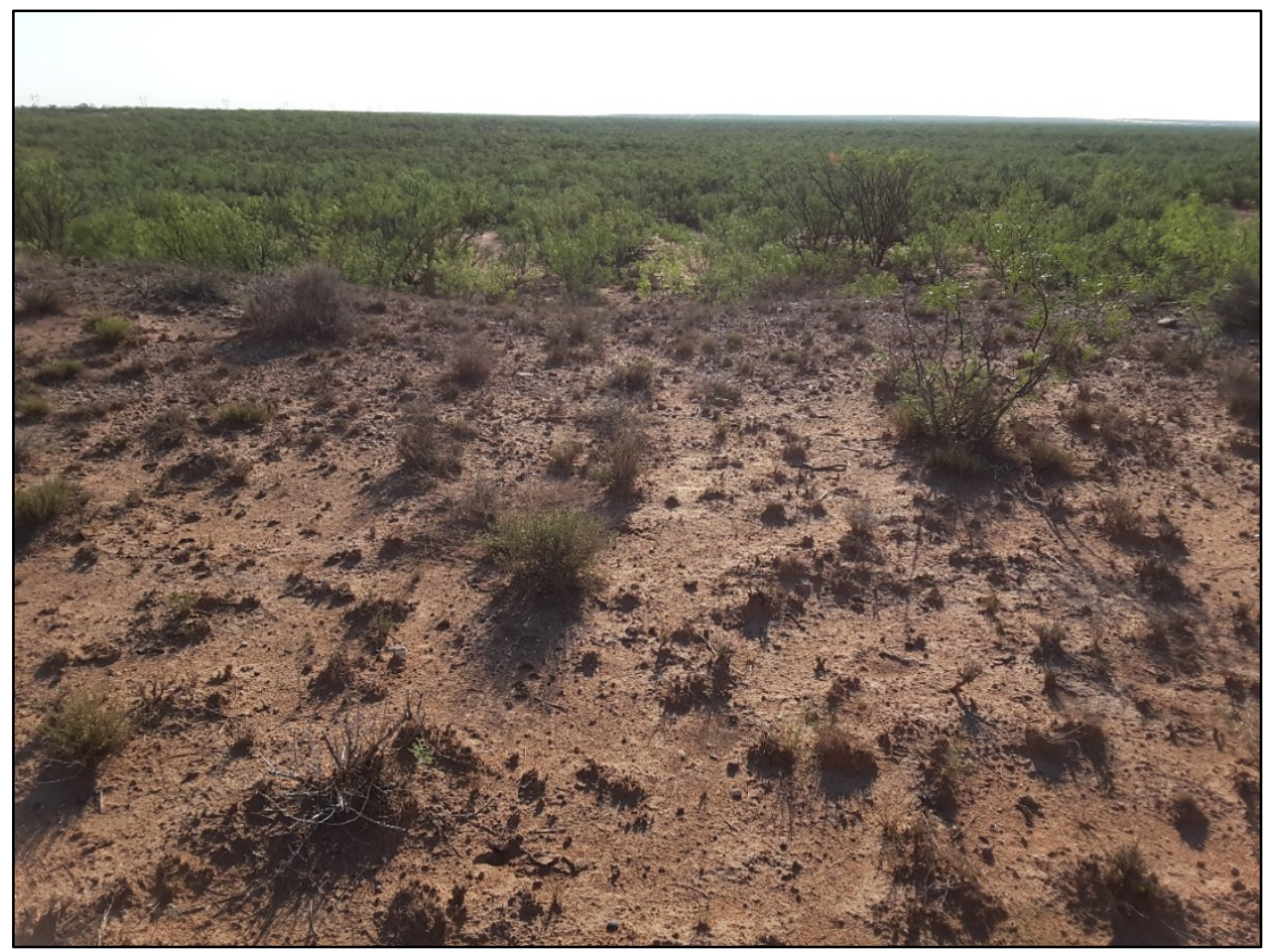

Figure 10. Overview of Auger03 test probe locale overlooking Pemberton Draw, facing northeast.

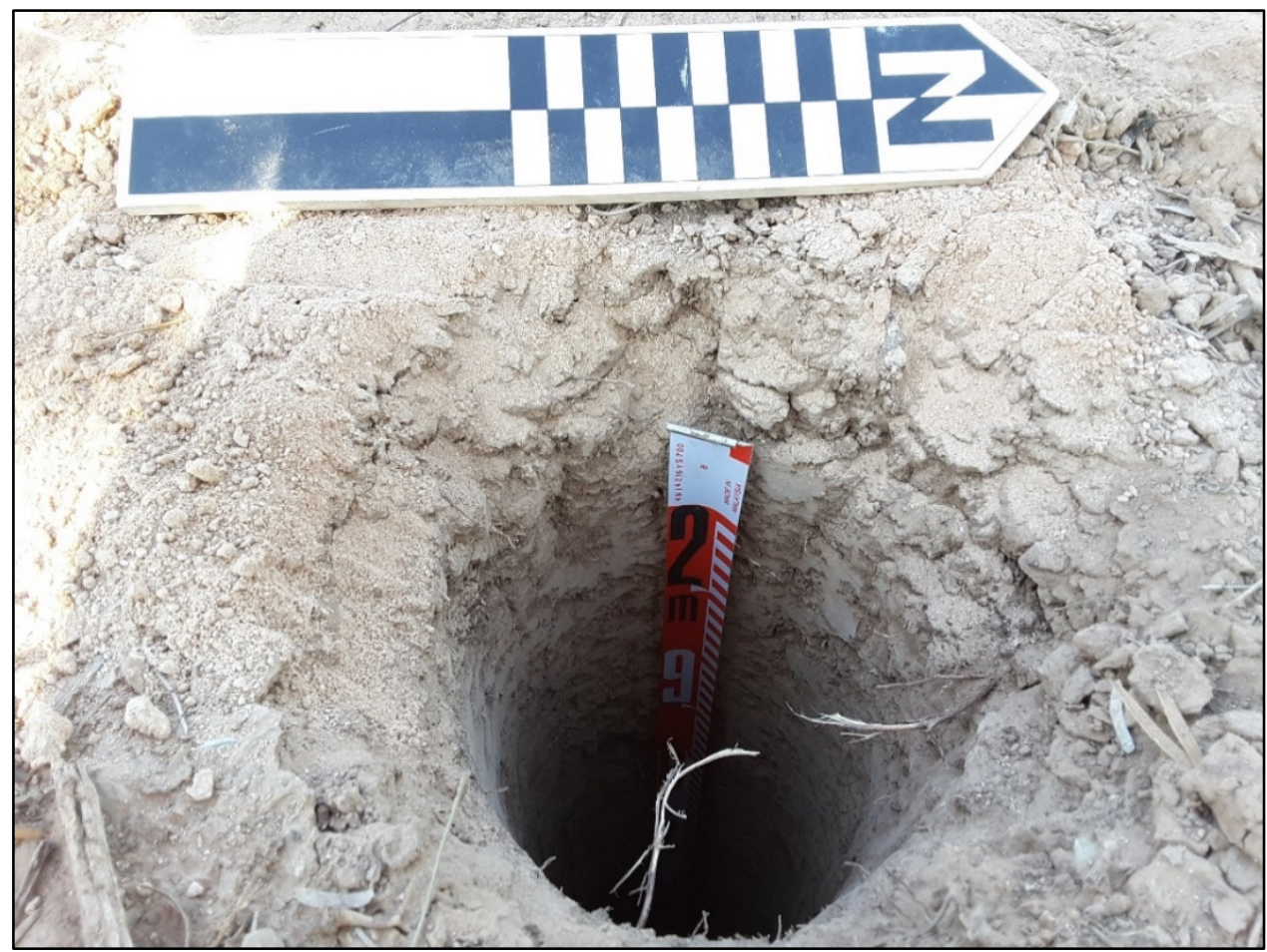

Figure 11. Auger04 test terminated at approximately $210 \mathrm{cmbs}$.

The investigations did not identify any prehistoric or historic cultural resource sites within the surveyed Project area. The area closest to previously identified site 41MD4 could not be accessed during the survey 
due to a pipeline fire directly adjacent to that location. SWCA planned an additional four shovel tests within the inaccessible Project components. Three of those tests were positioned within a heavily disturbed well pad area. The fourth unexcavated planned shovel test was 65 meters ( 215 feet) south of site 41MD4. This location was affected by the pipeline eruption. Local authorities did not permit access to the area after the event.

SWCA did not identify any evidence of previously identified site 41MD4 during the pedestrian survey and shovel testing along the Project area that crosses FM 1379 (Figure 12). SWCA field personnel completed a total of four negative shovel tests and one negative bucket auger test (Auger07) along this segment. Detailed subsurface testing data and associated soils are presented in Appendices B and C.

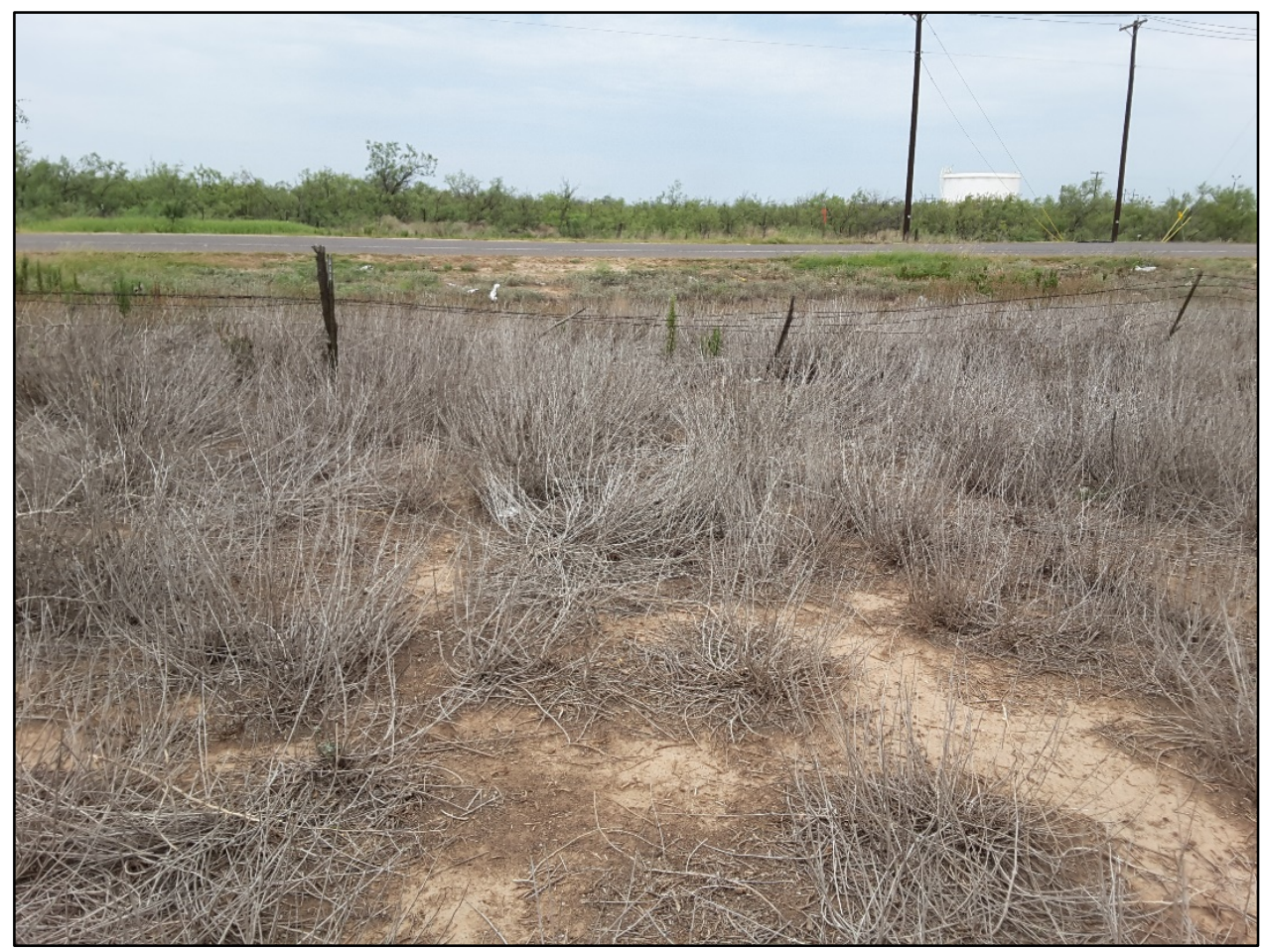

Figure 12. Overview of Project area crossing FM 1379, facing west toward site 41 MD4.

\section{SUMMARY AND RECOMMENDATIONS}

SWCA was retained by CrownQuest to complete an intensive cultural resources investigation for the proposed CrownQuest City of Midland Oil and Gas Project. The Project includes newly proposed oil and gas infrastructure within an established upstream system including well pads, crude oil pipeline, and associated access roads on City of Midland property in Midland and Glasscock Counties, Texas. The 149.9-acre (60.7-ha) Project area is located approximately 15 miles southeast of Midland, Texas, immediately south of Highway 158, and is situated along and between Johnson and Pemberton Draws.

Prior to the survey, SWCA conducted a thorough background literature reviews and archival research to identify cultural resources within and near the Project area. The background review determined that no previous cultural resources investigations intersect the Project area. However, one previously conducted cultural resources investigation was conducted within 1 mile of the Project area. In 2012, Pritchett Engineering \& Planning, LLC conducted a linear survey on behalf of the FERC. No additional information for this survey was available on the Atlas. The background review determined that one 
previously recorded archaeological site is located adjacent to the Project area boundary. Site 41MD4 is located 300 feet west of the gathering line, and is an Archaic open campsite consisting of a surficial lithic artifact scatter and fire-cracked rock. This site was originally documented in 1975 for the Johnson Draw Reservoir Project, and no recommendations for further work were made at that time.

From July 30 to August 3, 2018, SWCA archaeologists conducted an intensive archaeological survey of the Project area. Within much of the Project area, investigators encountered an eroded and heavily disturbed upland setting with occasional exposures of bedrock and caliche. Pedestrian survey was augmented with the excavation of 253 shovel tests and seven auger tests, which were terminated at the maximum reachable depth or at ancient soil likely predating human occupation of the area, which was typically $45 \mathrm{cmbs}$. The most pervasive disturbance was related to petroleum exploration and extraction activities that has greatly impacted the integrity of the ground surface across the Project area.

During the investigation SWCA archaeologists did not observe any prehistoric or historic cultural resources within the Project area. The location near site 41MD4, identified during the background review, could not be visited by SWCA survey staff due to a fire in the facility. The site boundary defined does not extend into a proposed Project activity area and the closest associated Project item is already disturbed. On that basis it is not considered to be a Project concern.

In the unlikely event that unanticipated cultural materials are encountered during subsequent construction activities, CrownQuest or their designated representative will immediately cease work within 100 feet $(30.5 \mathrm{~m})$ of the discovery. CrownQuest or their designated representative, should immediately notify THC. Work in the affected area could only resume per THC authorization.

Overall, SWCA made a reasonable and good faith effort to identify significant cultural resource sites within the Project area. SWCA completed all work in accordance with the ACT and CTA/THC guidelines. Based on the negative findings of the intensive cultural resources survey, SWCA recommends that no further archaeological investigations are warranted within the assessed portions of the CrownQuest City of Midland Oil and Gas Project area. 


\section{REFERENCES}

Blair, W. Frank

1950 The Biotic Provinces of Texas. The Texas Journal of Science 2(1):93-117.

Blake, R. B.

2003 Salas, Juan De. The Handbook of Texas Online. Texas State Historical Association, Austin. Accessed August 14, 2018.

Boyd, D. K.

1995 The Palo Duro Complex: Redefining the Early Ceramic Period in the Caprock Canyonlands. Bulletin of the Texas Archeological Society 66:461-518.

Campbell, T. N.

1983 The Coahuiltecans and Their Neighbors. Handbook of North American Indians 10:343-358.

Collins, M.

1995 Forty Years of Archeology in Central Texas. Bulletin of the Texas Archeology Society 66:361-400.

Dillehay, T. D.

1974 Late Quaternary Bison Population Changes on the Southern Plains. Plains Anthropologist 19(65):180-196.

Donoghue, David

2003 Coronado Expedition. The Handbook of Texas Online. Texas State Historical Association, Austin. Accessed August 10, 2018.

Eifler, Jr., G. K., J. C. Frye, A. B. Leonard, and Barnes, Virgil E.

1994 Geologic Atlas of Texas, Big Spring Sheet. Revised Edition. Vincent Charles Perini, Jr., Memorial Edition. Bureau of Economic Geology, The University of Texas, Austin.

Foster, T. R., T. Summerville, and T. Brown

2006 The Texas Historic Overlay: A Geographic Information System of Historic Map Images for Planning Transportation Projects in Texas. Prepared for the Texas Department of Transportation by PBS\&J, Austin.

Frye, J.C. and Leonard, A. B.

1957 Studies of Cenozoic geology along eastern margin of Texas High Plains, Armstrong to Howard Counties: University of Texas Bur. Econ. Geology, Rept, Inv. 32, 62 p.

Studies of Cenozoic geology along eastern margin of Texas High Plains, Armstrong to Howard Counties: University of Texas Bur. Econ. Geology, Rept, Inv. 32, 62 p.

Griffith, G.E., S.A. Bryce, J.M. Omernik, J.A. Comstock, A.C. Rogers, B. Harrison, S.L. Hatch, and D. Bezanson

2007 Ecoregions of Texas (color poster with map, descriptive text, and photographs). Map scale 1:2,500,000. Reston, Virginia, U.S. Geological Survey. 
Hays, J. S.

1989 Appendix I: Historic Tribal Groups in the Southern Great Plains. In From Clovis to Comanchero: Archeological Overview of the Southern Great Plains, by J. L. Hofman, R. L. Brooks, J. S. Hays, D. W. Owsley, R. L. Jantz, M. K. Marks, and M. H. Manhein, pp. 247262. Research Series No. 35. Arkansas Archeological Survey, Fayetteville.

Hays, J. S., R. L. Brooks, and J. L. Hofman

1989 Historical Archeology in the Southern Great Plains. In From Clovis to Comanchero: Archeological Overview of the Southern Great Plains, by J. L. Hofman, R. L. Brooks, J. S. Hays, D. W. Owsley, R. L. Jantz, M. K. Marks, and M. H. Manhein, pp. 101-110. Research Series No. 35. Arkansas Archeological Survey, Fayetteville.

Hofman, J. L.

1989 Prehistoric Culture History-Hunters and Gatherers in the Southern Great Plains. In From Clovis to Comanchero: Archeological Overview of the Southern Great Plains, by J. L. Hofman, R. L. Brooks, J. S. Hays, D. W. Owsley, R. L. Jantz, M. K. Marks, and M. H. Manhein, pp. 25-60. Research Series No. 35. Arkansas Archeological Survey, Fayetteville.

Holden, W. C.

2003 Comanche Trail. Handbook of Texas Online. Texas State Historical Association, Austin. Accessed August 2018.

Holliday, V.T.

1989 The Blackwater Draw Formation (Quarternary): A 1.4-plus-m.y. Record of Eolian Sedimentation and Soil Formation on the Southern High Plains. Bulletin of the Geological Society of America 101 (12): 1598-1607.

1997 Paleoindian Geoarchaeology of the Southern High Plains. University of Texas Press, Austin.

Johnson, E., and V. T. Holliday

1995 Archeology and Late Quaternary Environments of the Southern High Plains. Bulletin of the Texas Archeological Society 66:519-540.

Kelly, R. L., and L. C. Todd

1988 Coming into the Country, Early Paleoindian Hunting and Mobility. American Antiquity 53:231-244.

National Park Service

1983 Archeology and Historic Preservation: Secretary of the Interior's Standards and Guidelines. Federal Register 48 (190): 44734-44742.

Natural Resources Conservation Service (NRCS)

2018 Soil Survey Staff, Natural Resources Conservation Service, United States Department of Agriculture. Web Soil Survey of Travis County. Available at http://websoilsurvey.nrcs.usda.gov/. Accessed July 2018.

Sheffield, W. J., Jr.

2001 Historic Texas Tours: A Guide for Tracing Early Routes and Trails. Eakin Press, Austin, Texas. 
Texas Historical Commission (THC)

2018 Texas Archeological Sites Atlas restricted database, Texas Historical Commission. Available at http://nueces.thc.state.tx.us/. Accessed August 2018.

\section{U.S. Geological Survey (USGS)}

2018 TopoView: historical topographic map collection. Published by the U.S. Geological Survey (USGS). Available at: http://ngmdb.usgs.gov/maps/TopoView. Accessed August 2018. 
Cultural Resources Investigations

for the CrownQuest City of Midland Oil and Gas Project

This page intentionally left blank. 


\section{APPENDIX A}

Survey Results Maps 
This page intentionally left blank. 


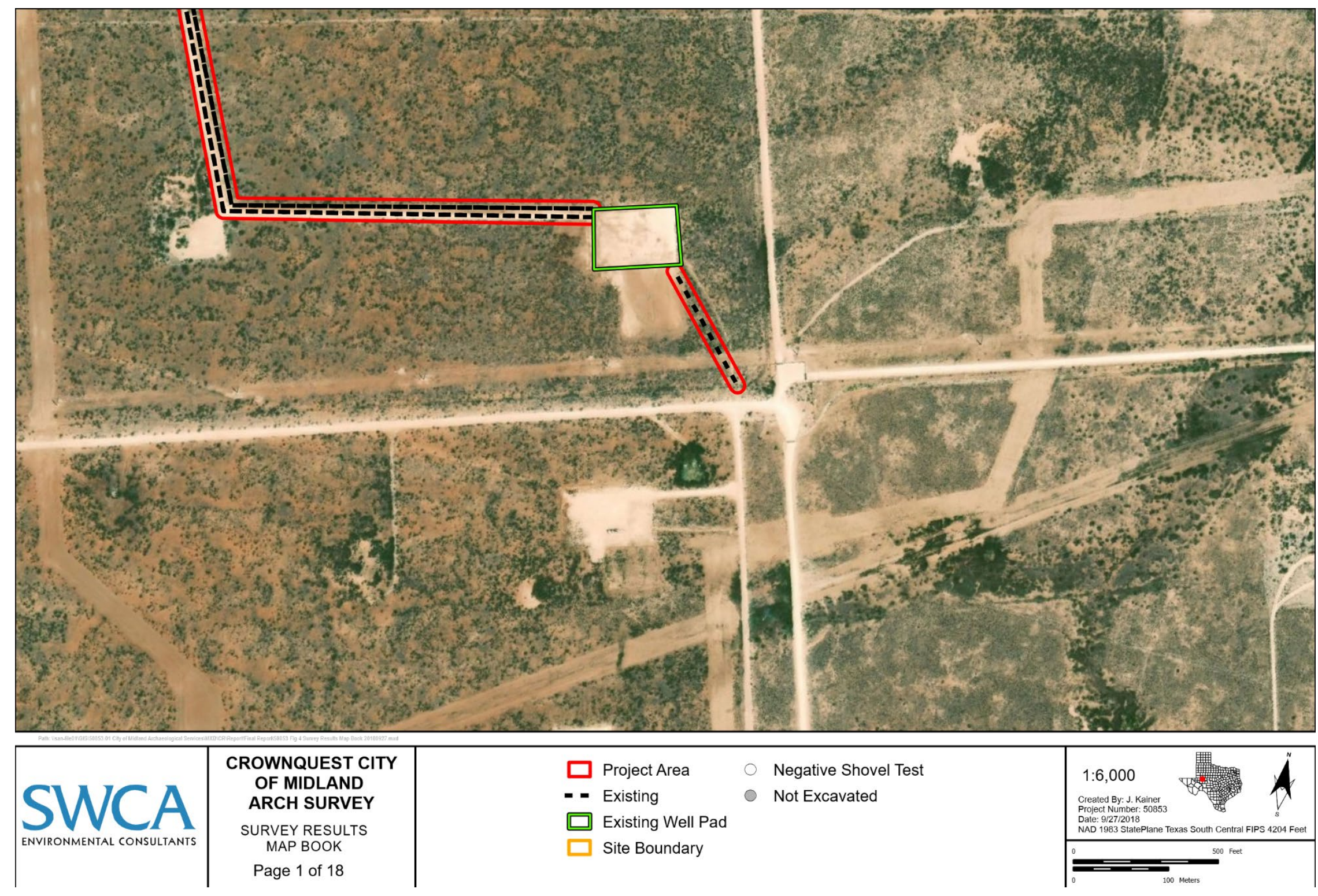




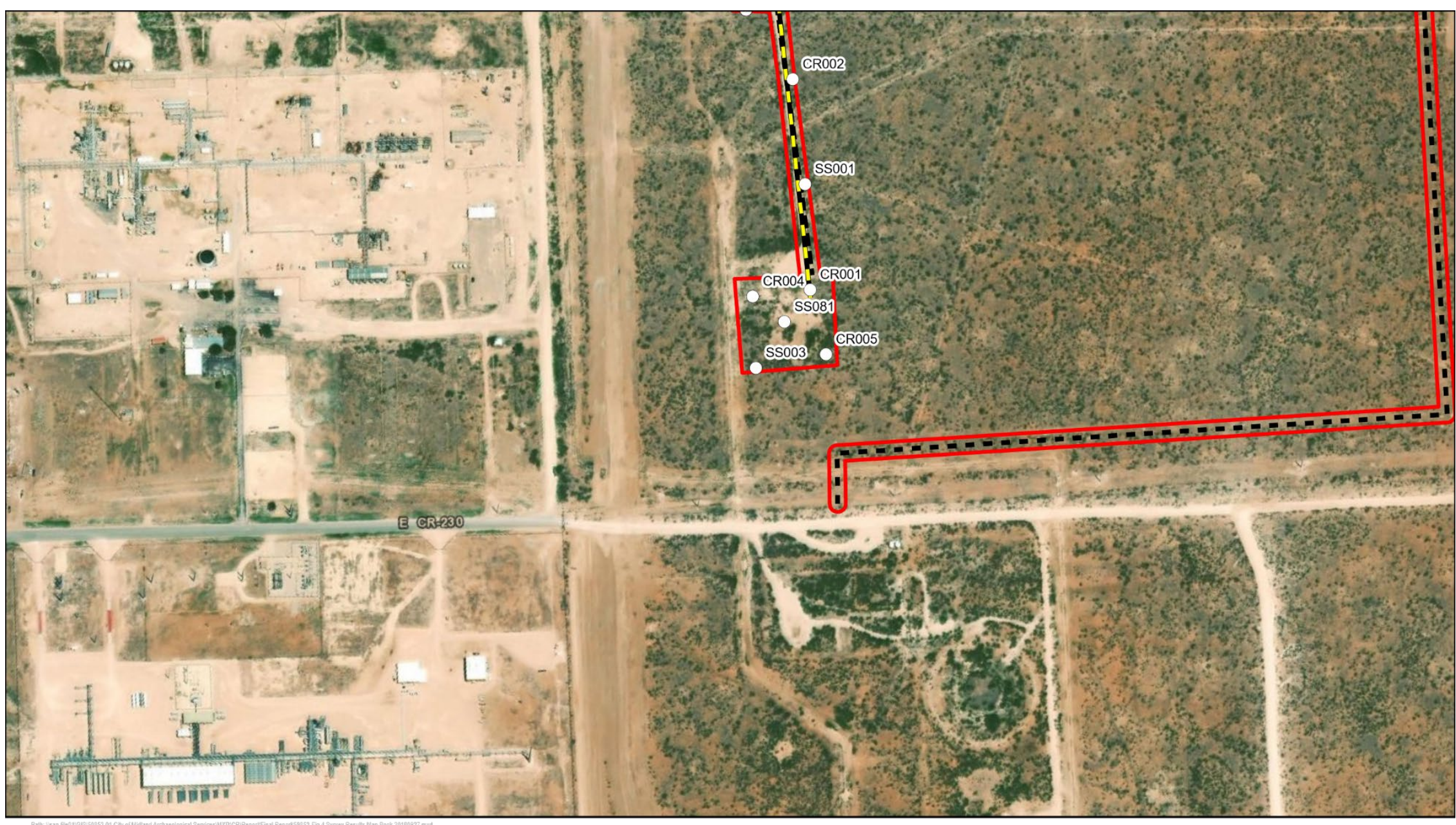

CROWNQUEST CITY

OF MIDLAND ARCH SURVEY

SURVEY RESULTS

AP BOOK

Page 2 of 18 $\square$ Project Area

- - Existing

- Proposed Pipeline

$\square$ Site Boundary
- Negative Shovel Test

- Not Excavated

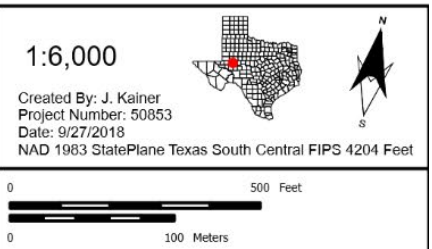




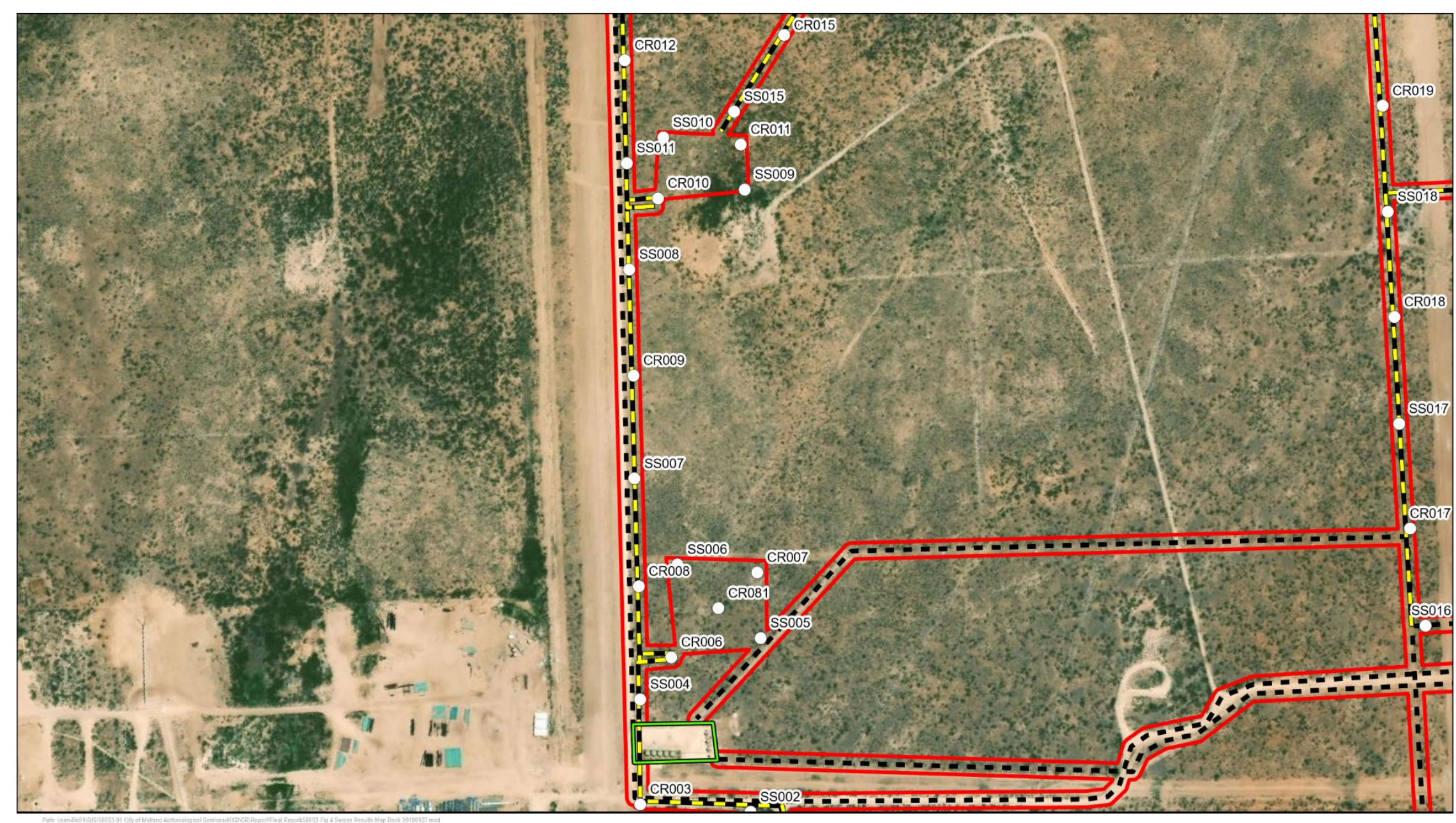

CROWNQUEST CITY

OF MIDLAND ARCH SURVEY

SURVEY RESULTS

AP BOOK

Page 3 of 18 $\square$ Project Area

- - Existing

- Proposed Pipeline

$\square$ Existing Well Pad $\square$ Site Boundary

- Negative Shovel Test

Not Excavated

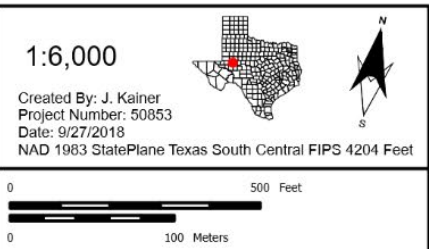




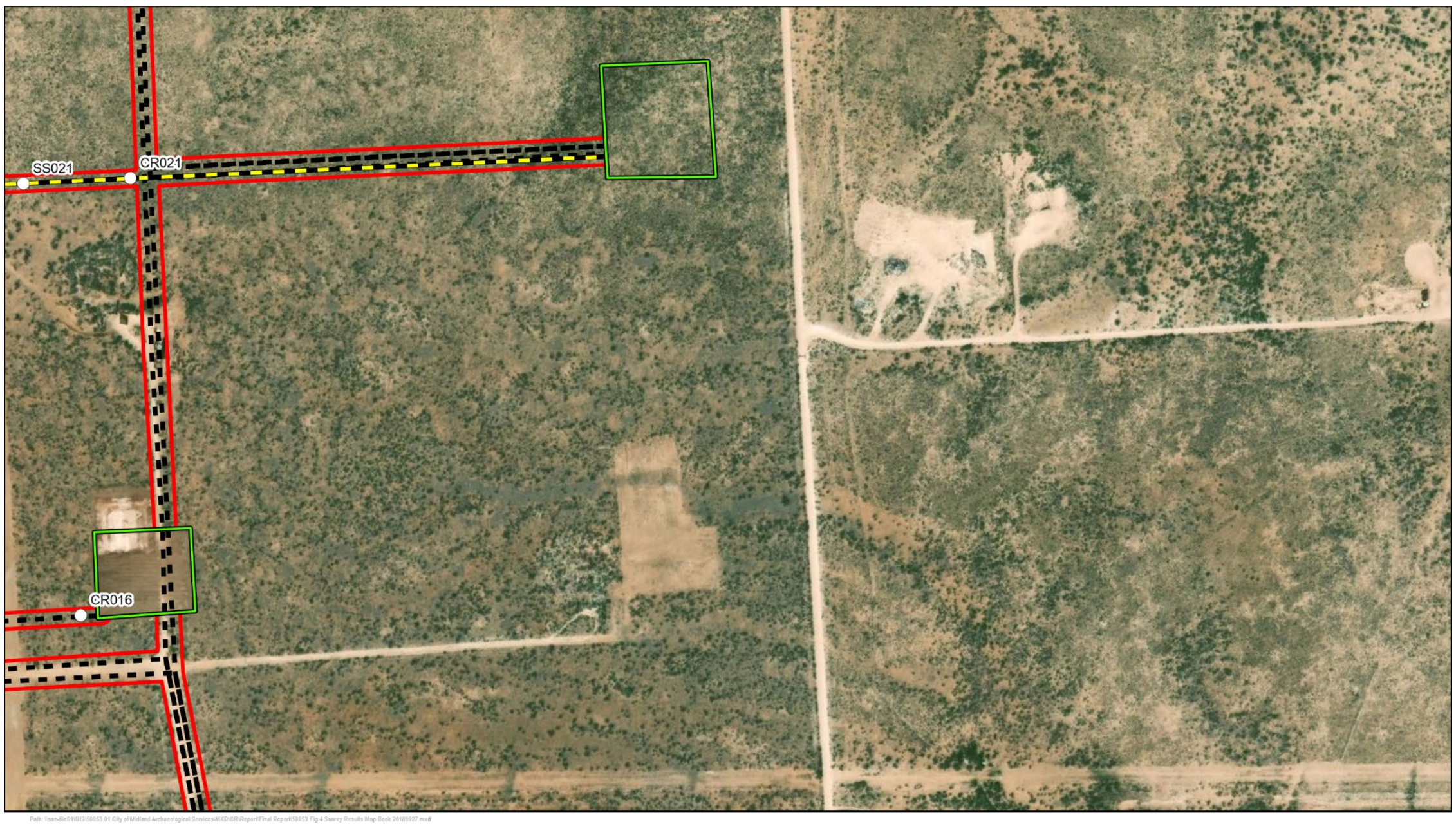

CROWNQUEST CITY

OF MIDLAND ARCH SURVEY

SURVEY RESULTS

AP BOOK

Page 4 of 18
$\square$ Project Area
- - Existing
$\square$ Site Boundary
- Negative Shovel Test
- Proposed Pipeline
Not Excavated
$\square$ Existing Well Pad

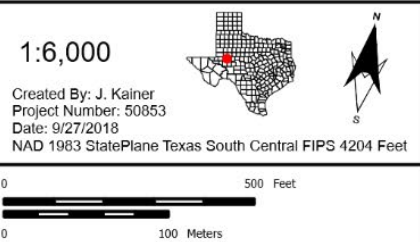




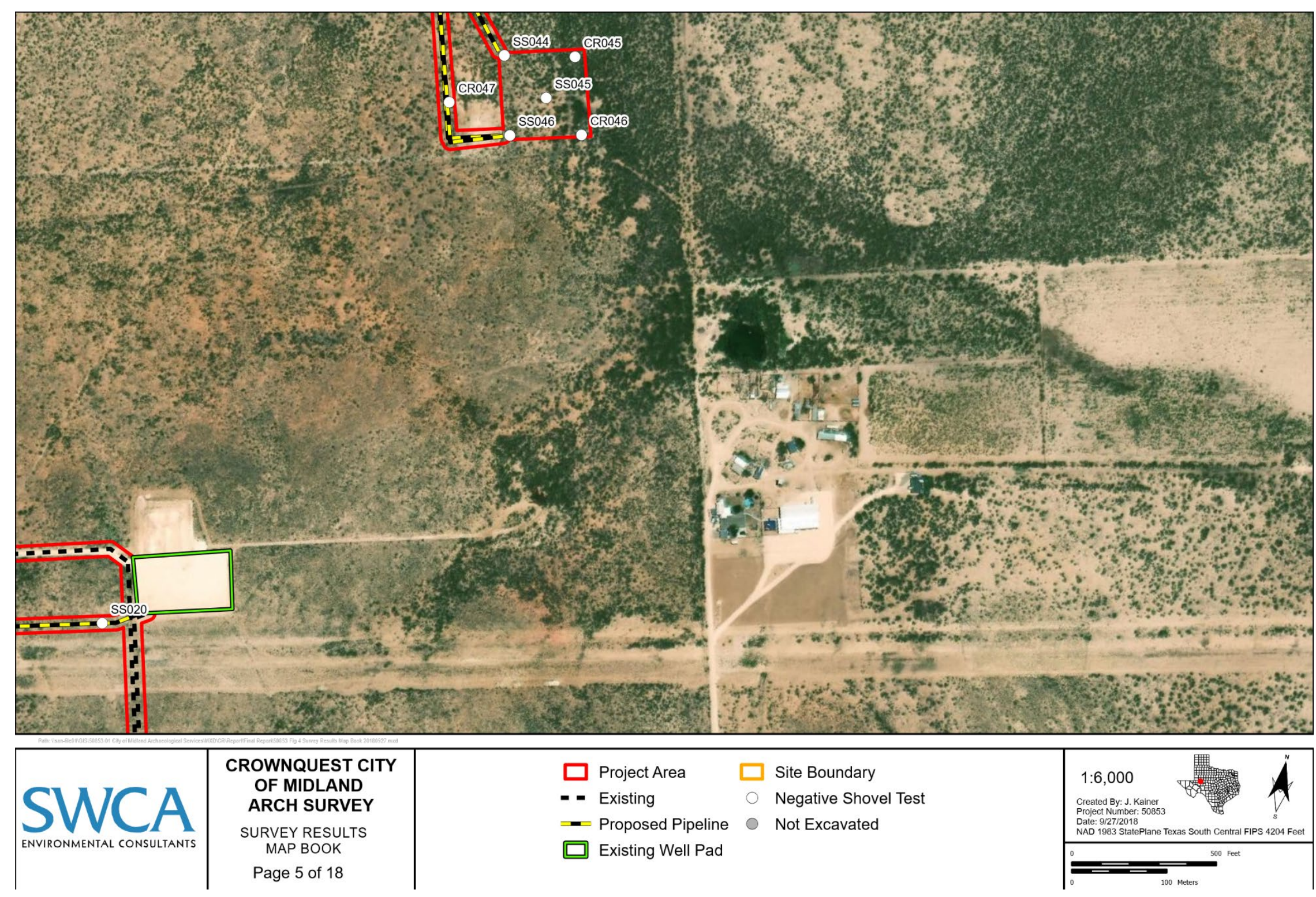




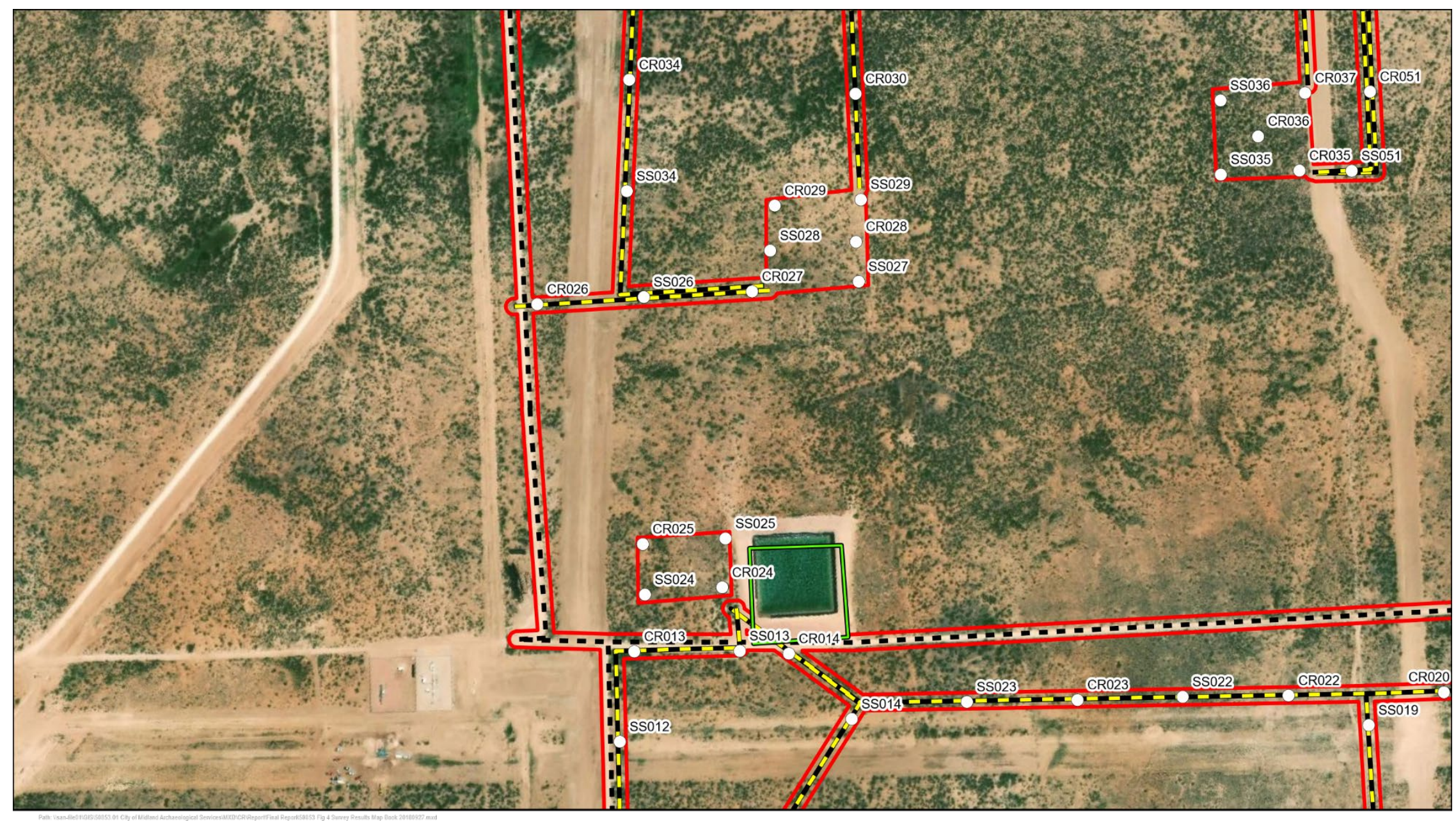

CROWNQUEST CITY

OF MIDLAND ARCH SURVEY

SURVEY RESULTS

MAP BOOK

Page 6 of 18
$\square$ Project Area
- - Existing
$\square$ Site Boundary
- Negative Shovel Test
- Proposed Pipeline
Not Excavated
$\square$ Existing Well Pad

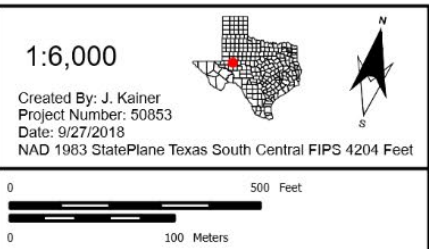




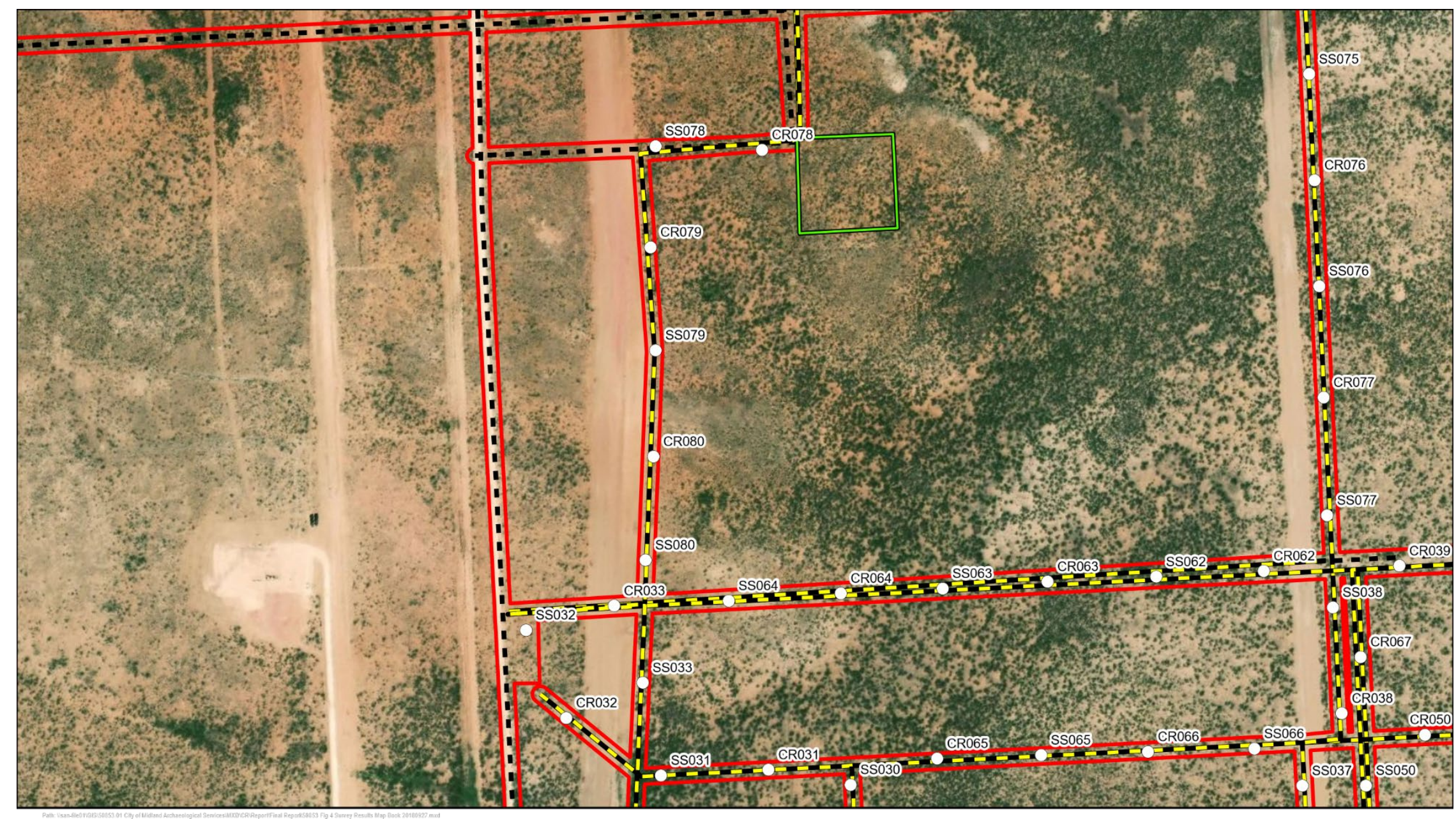

CROWNQUEST CITY

OF MIDLAND ARCH SURVEY

SURVEY RESULTS

AP BOOK

Page 7 of 18
$\square$ Project Area
- - Existing
$\square$ Site Boundary
- Negative Shovel Test
- Proposed Pipeline
- Not Excavated
$\square$ Existing Well Pad

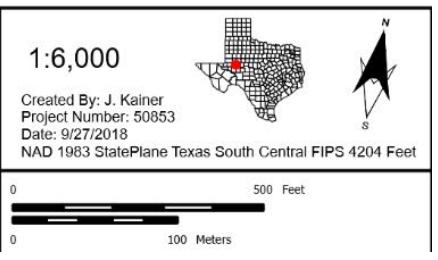




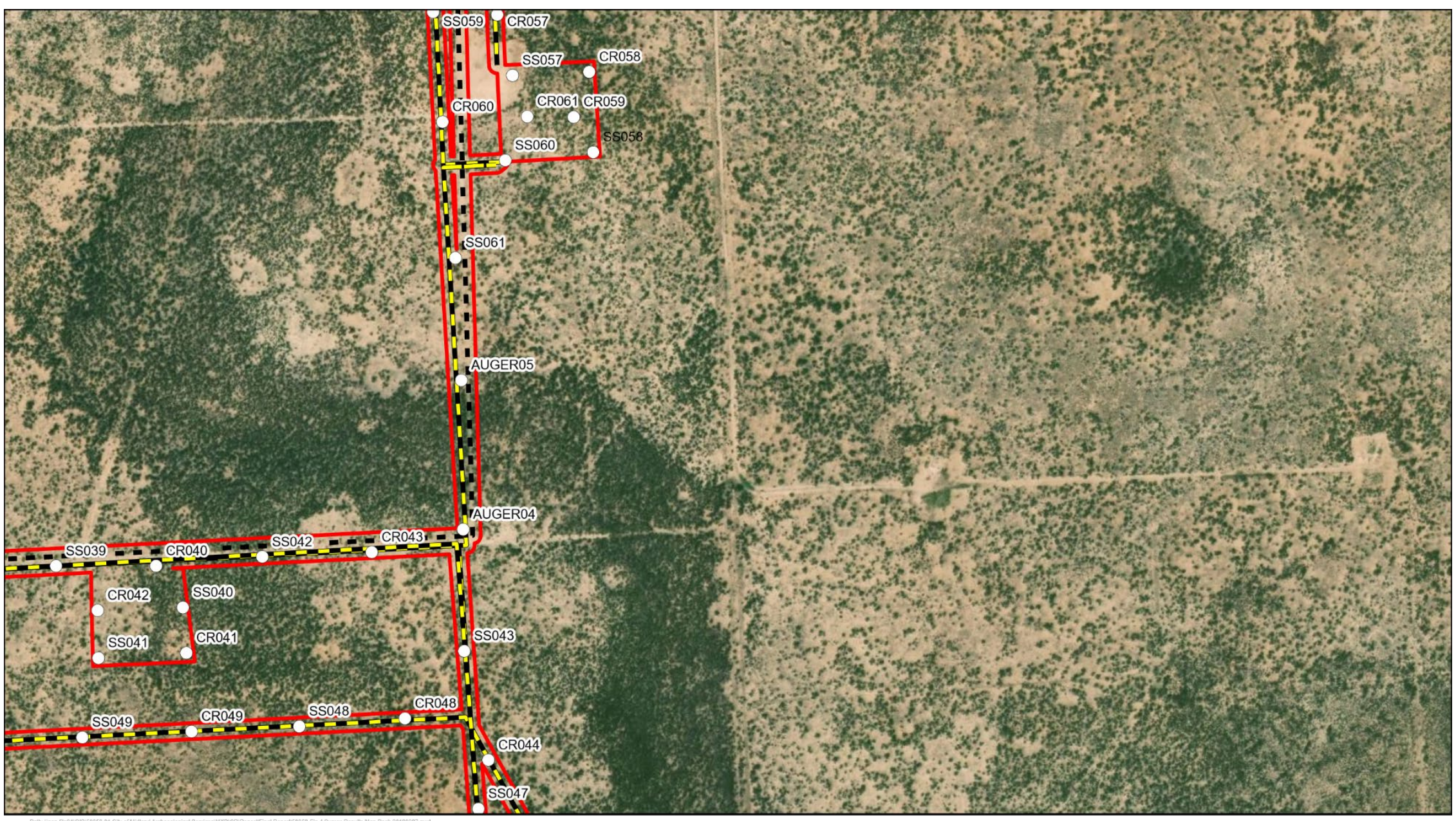

CROWNQUEST CITY

OF MIDLAND ARCH SURVEY

SURVEY RESULTS

Page 8 of 18 $\square$ Project Area

- - Existing

- Proposed Pipeline

$\square$ Site Boundary
Negative Shovel Test

- Not Excavated

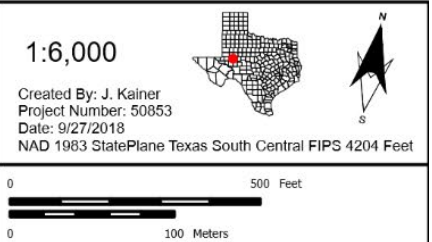




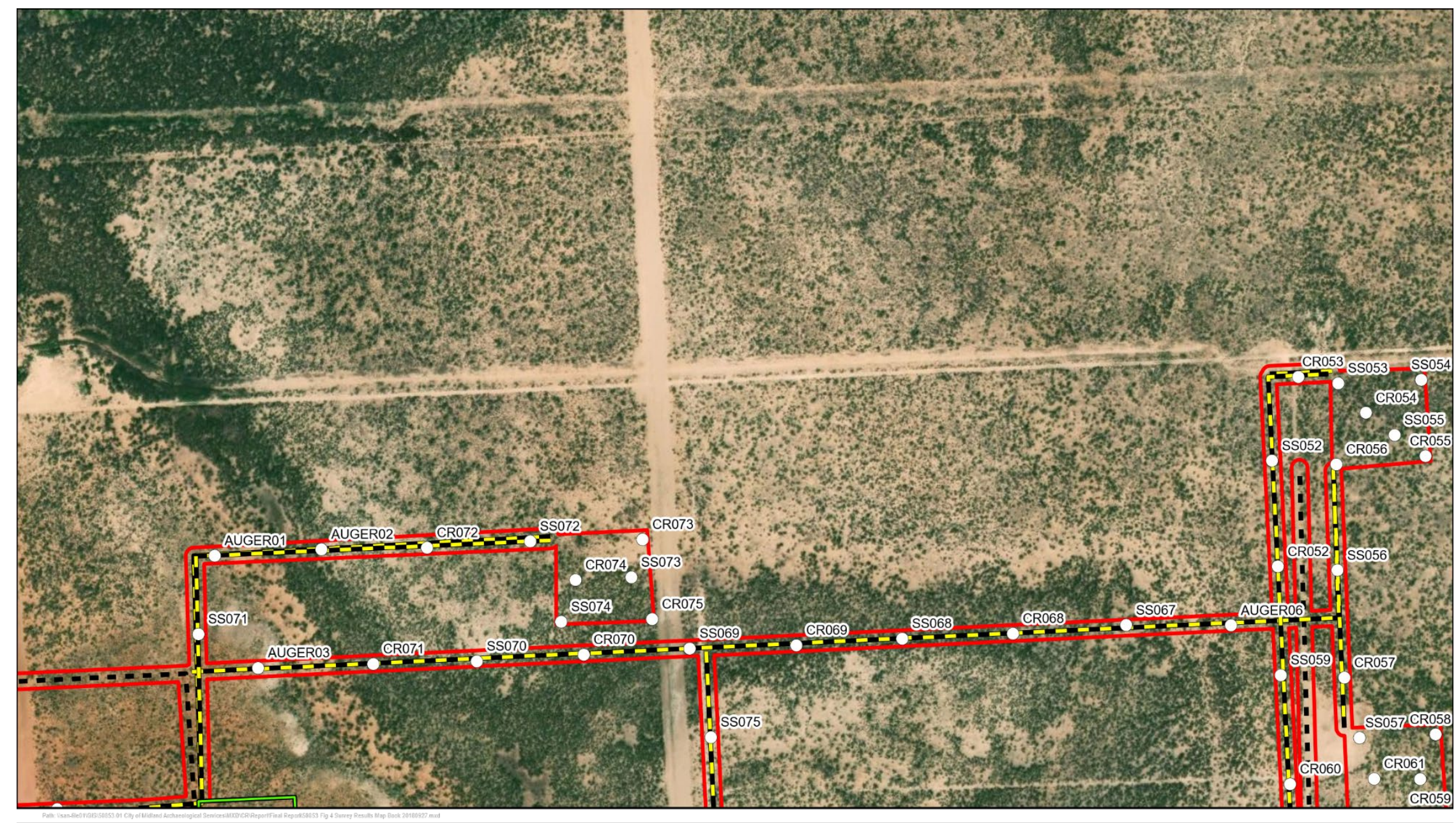

CROWNQUEST CITY

OF MIDLAND ARCH SURVEY

SURVEY RESULTS

Page 9 of 18
$\square$ Project Area
- - Existing
$\square$ Site Boundary
- Negative Shovel Test
- Proposed Pipeline
- Not Excavated
$\square$ Existing Well Pad

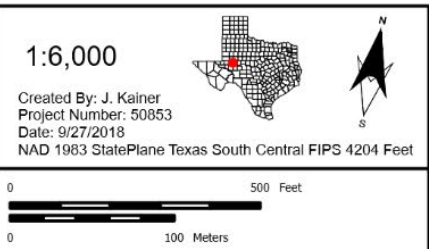




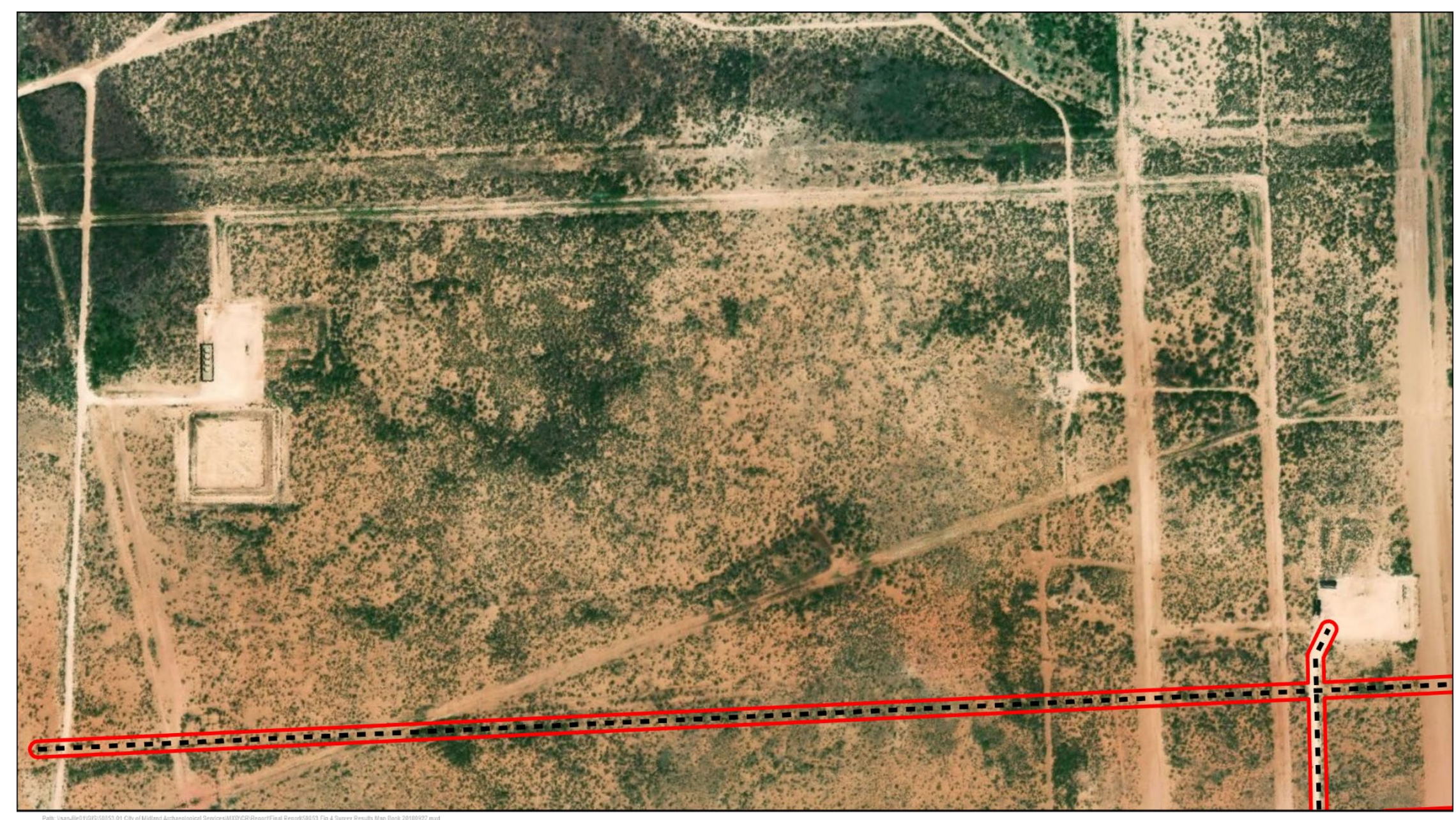

CROWNQUEST CITY

OF MIDLAND ARCH SURVEY

SURVEY RESULTS

BOOK

Page 10 of 18
$\square$ Project Area
- - Existing
$\square$ Site Boundary
- Negative Shovel Test

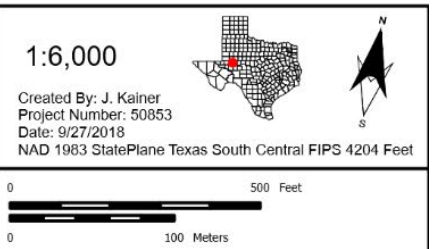




\section{Restricted Information}

Not for Public Disclosure 


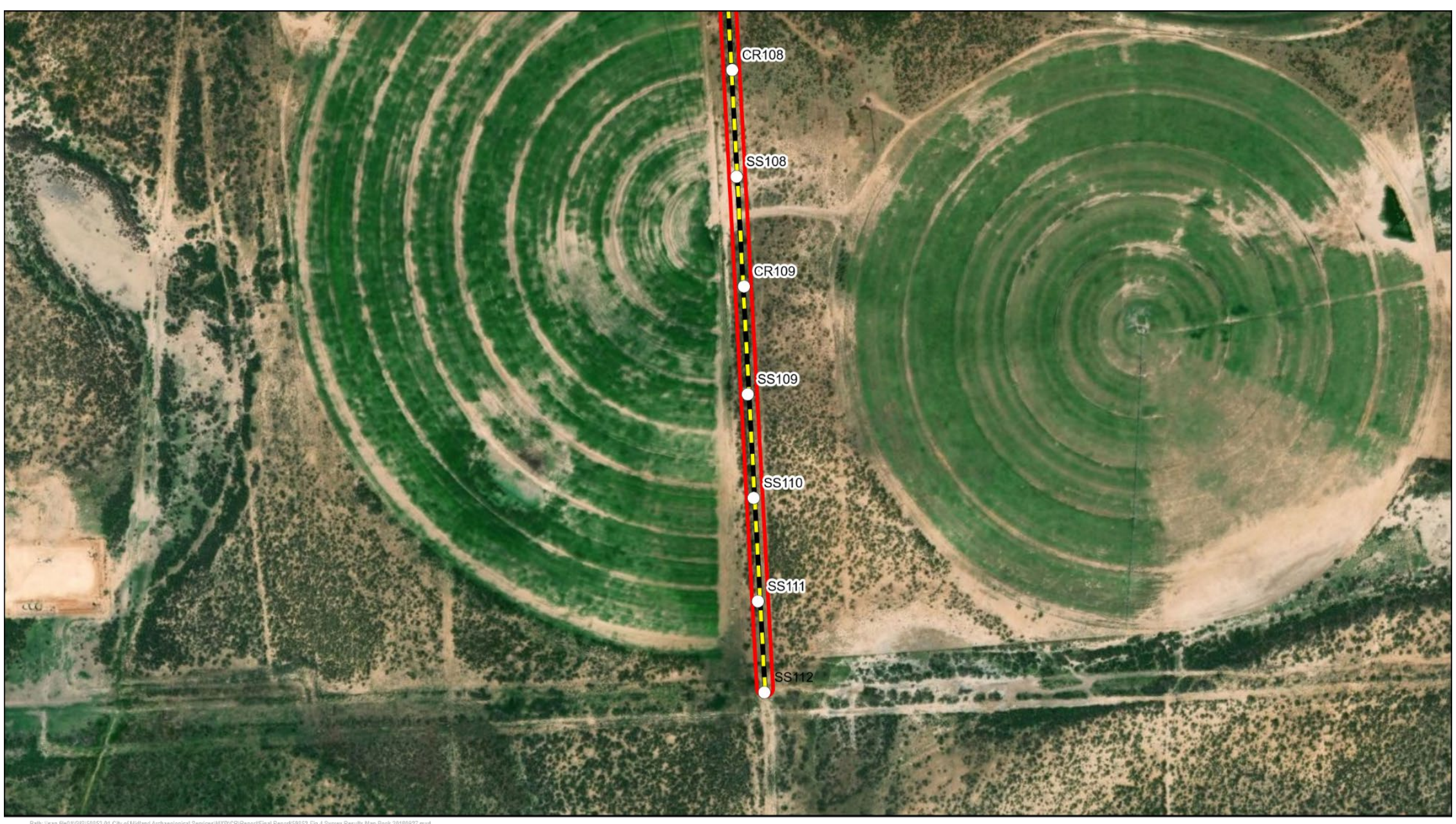

CROWNQUEST CITY

OF MIDLAND ARCH SURVEY

SURVEY RESULTS

AP BOOK

Page 12 of 18
$\square$ Project Area
- Proposed Pipeline
$\square$ Site Boundary
- Negative Shovel Test

Not Excavated

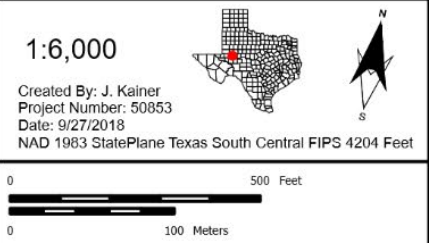




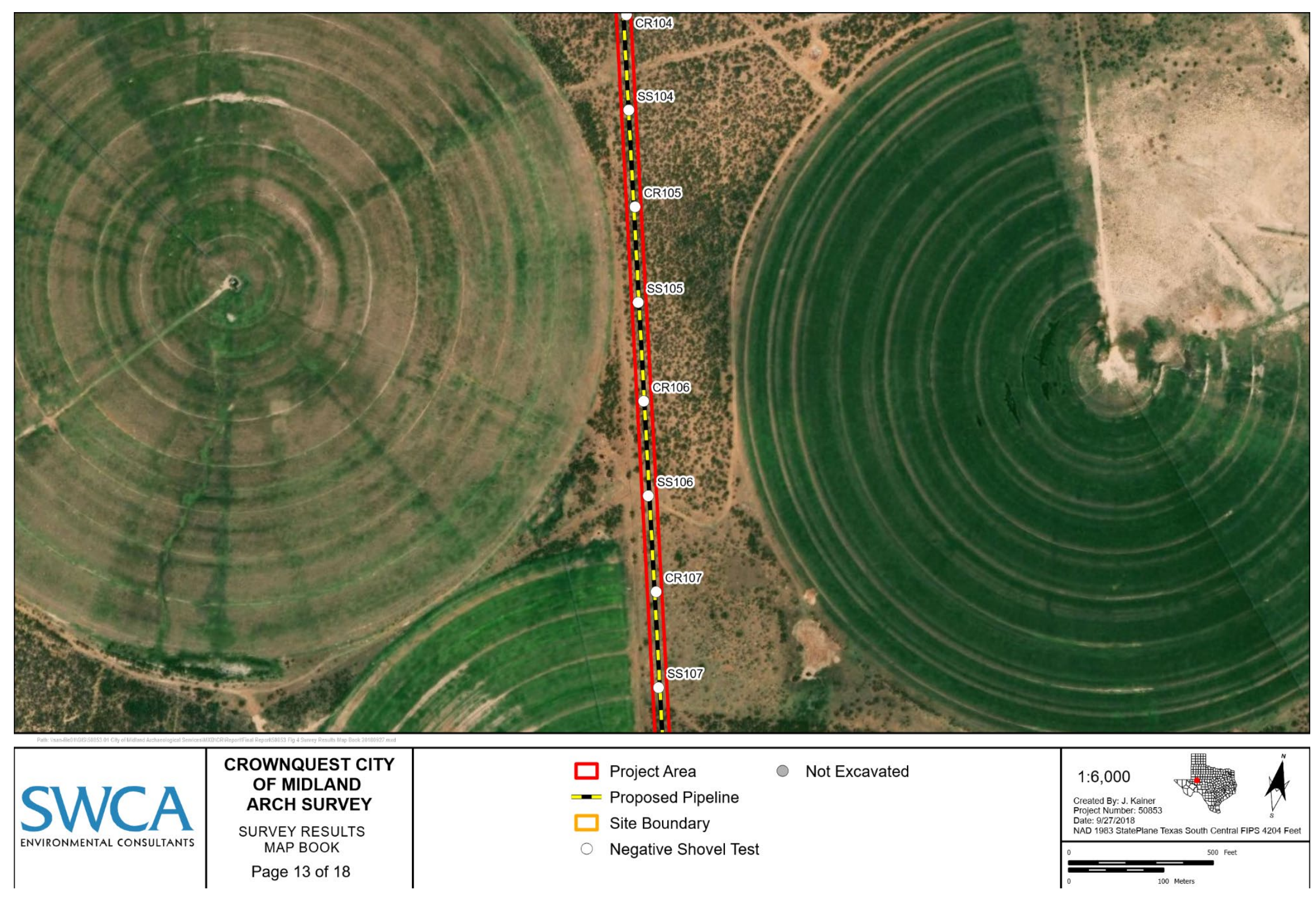




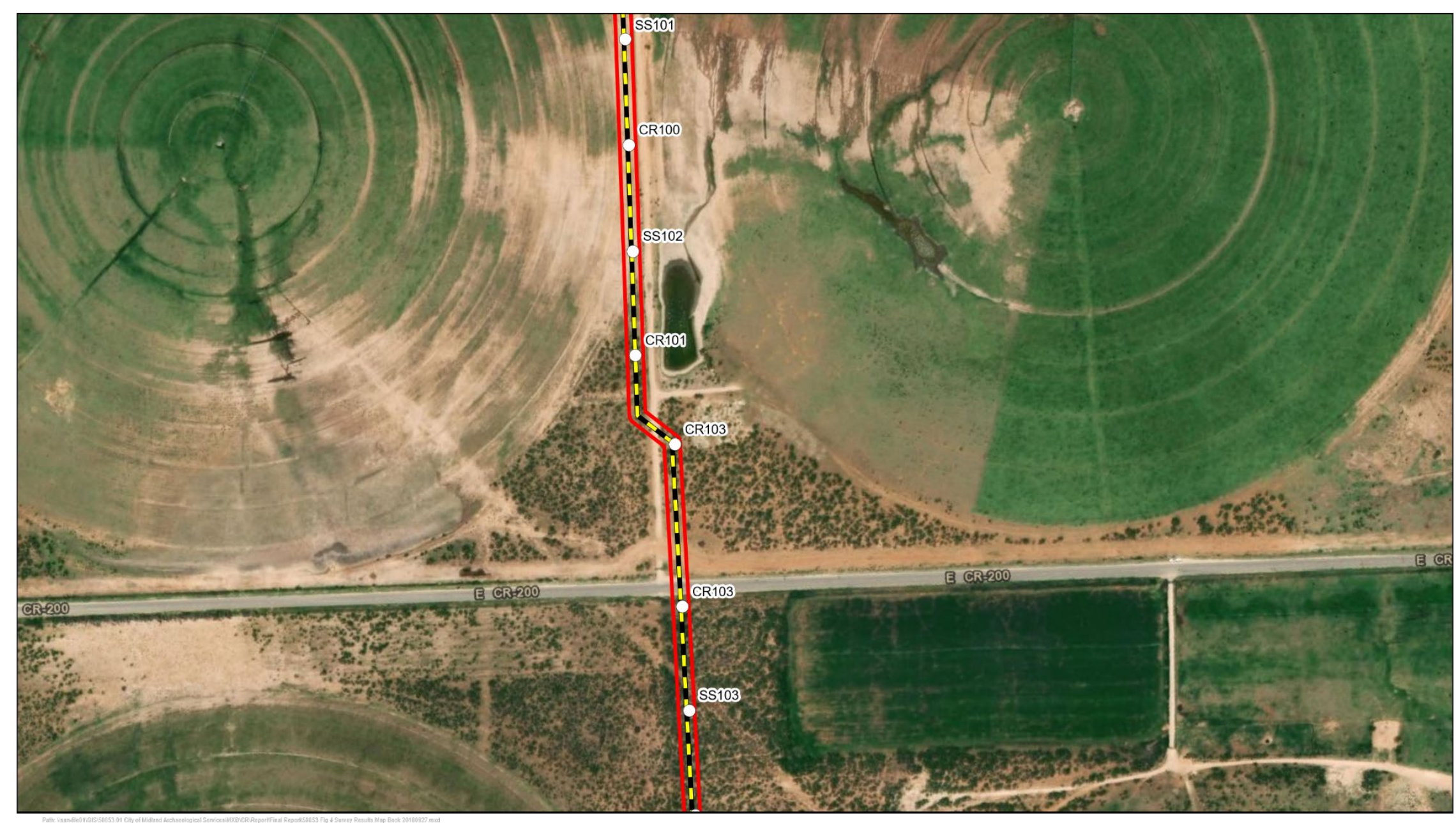

CROWNQUEST CITY

OF MIDLAND ARCH SURVEY

SURVEY RESULTS

MAP BOOK

Page 14 of 18
$\square$ Project Area
- Proposed Pipeline
$\square$ Site Boundary
- Negative Shovel Test

- Not Excavated

$1: 6,000$

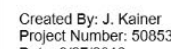

S100 Feet 


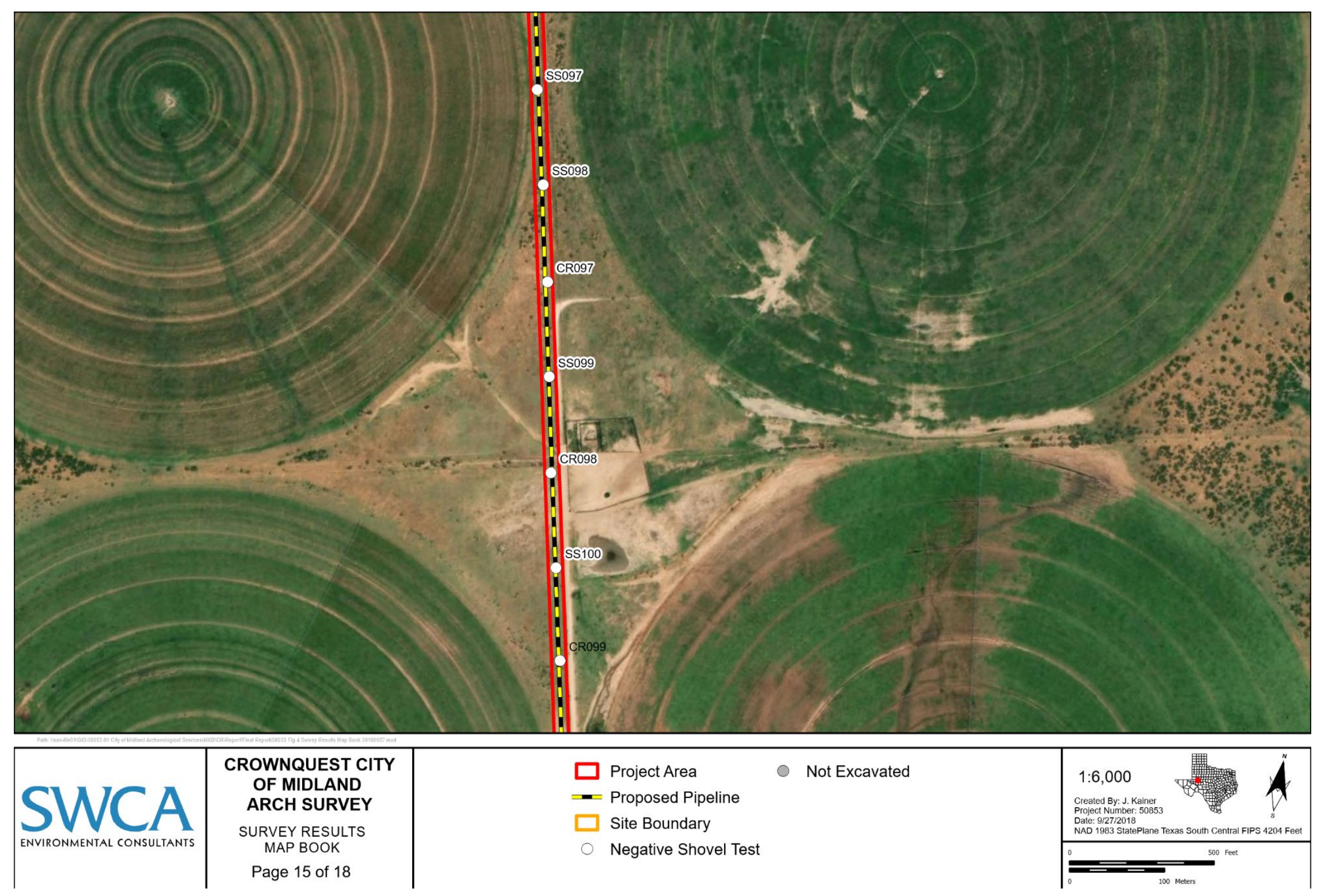




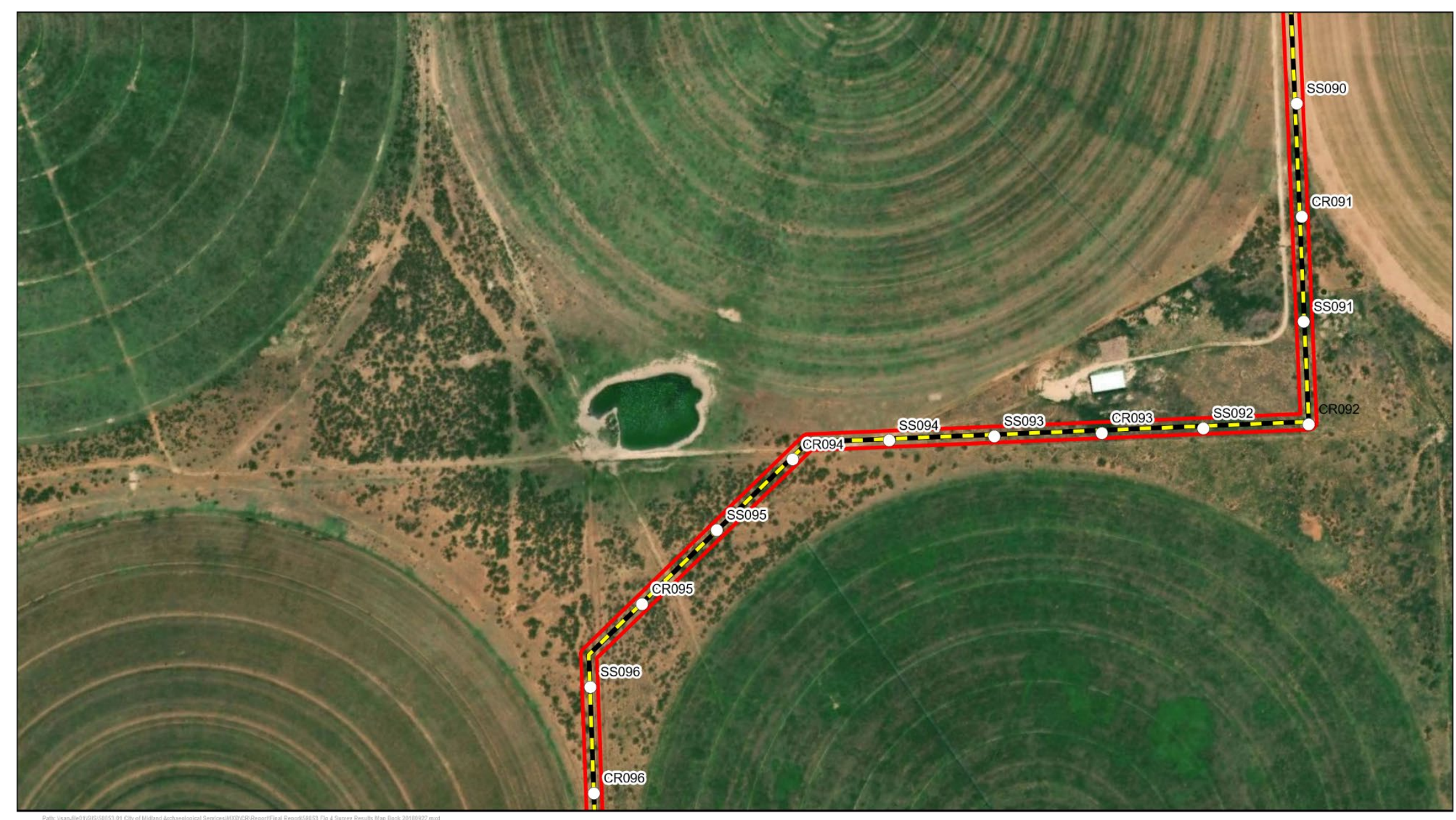

CROWNQUEST CITY

OF MIDLAND ARCH SURVEY

SURVEY RESULTS

MAP BOOK

Page 16 of 18 $\square$ Project Area

- Proposed Pipeline

$\square$ Site Boundary

- Negative Shovel Test
Not Excavated

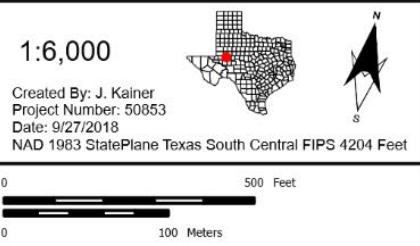




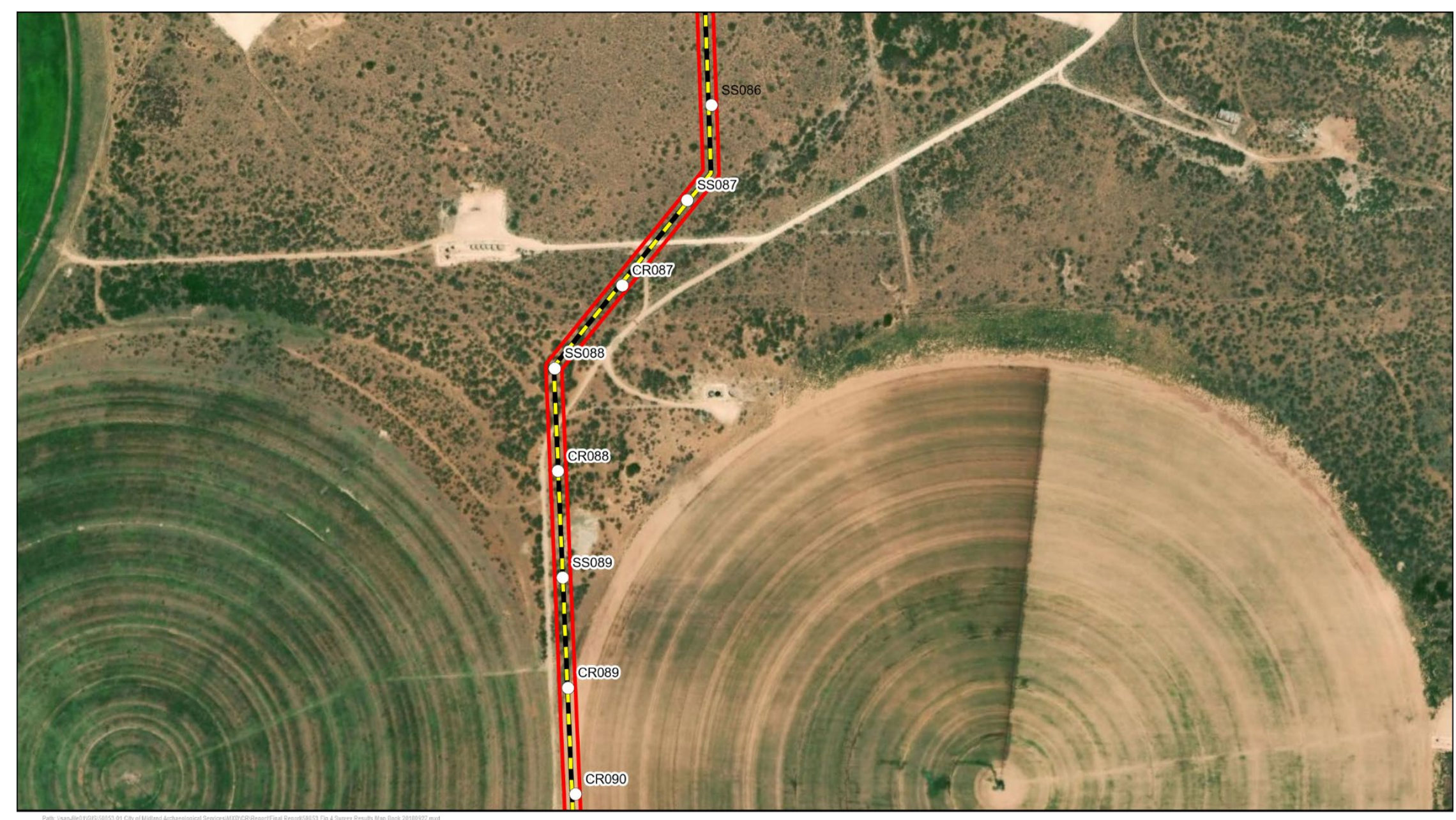

CROWNQUEST CITY

OF MIDLAND ARCH SURVEY

SURVEY RESULTS

BOOK

Page 17 of 18 $\square$ Project Area

- Proposed Pipeline

$\square$ Site Boundary

- Negative Shovel Test
Not Excavated

$1: 6,000$

Created By: J. Kainer
Project Number: 50853

1983 StatePlane Texas South Central FIPS 4204 Feet

ב 100 Meters 


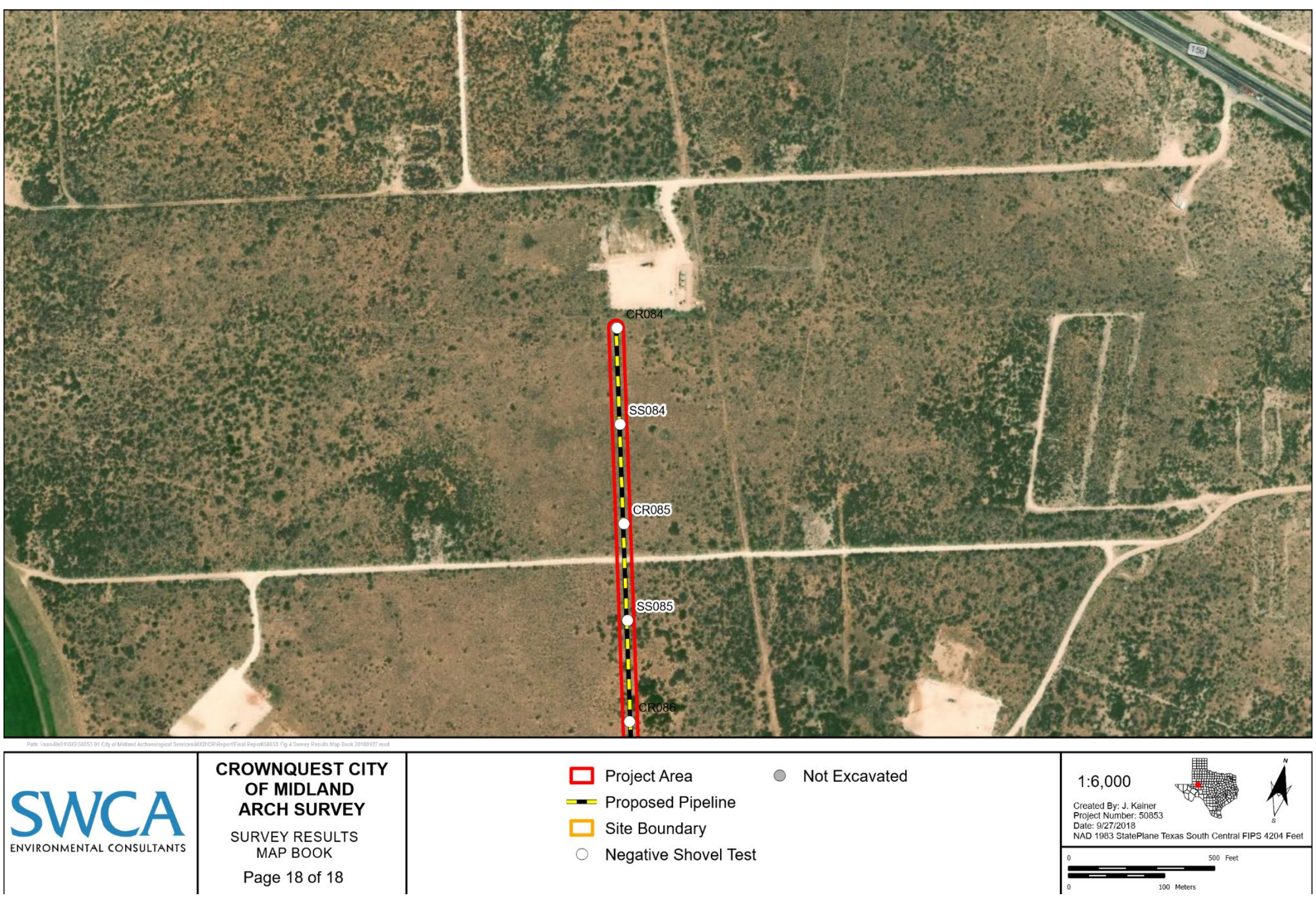




\section{APPENDIX B}

Shovel Test Results 
This page intentionally left blank. 


\begin{tabular}{|c|c|c|c|c|c|c|c|}
\hline $\begin{array}{l}\text { STP } \\
\text { No. }\end{array}$ & $\begin{array}{l}\text { Depth } \\
\text { (cmbs) }\end{array}$ & Munsell & Soil Color & $\begin{array}{l}\text { Soil } \\
\text { Texture }\end{array}$ & Inclusions & $\begin{array}{l}\text { Positive/ } \\
\text { Negative }\end{array}$ & $\begin{array}{l}\text { Comments/ } \\
\text { Reason for Termination }\end{array}$ \\
\hline CR001 & $0-15$ & $\begin{array}{l}10 Y R \\
5 / 3\end{array}$ & Brown & $\begin{array}{l}\text { Sandy } \\
\text { Loam }\end{array}$ & $>20 \%$ Gravels & Negative & $\begin{array}{l}\text { No cultural material } \\
\text { encountered. Terminated } \\
\text { at compact soil. }\end{array}$ \\
\hline CR002 & $0-35$ & $\begin{array}{l}10 Y R \\
5 / 3\end{array}$ & Brown & $\begin{array}{l}\text { Sandy } \\
\text { Loam }\end{array}$ & $>20 \%$ Gravels & Negative & $\begin{array}{l}\text { No cultural material } \\
\text { encountered. Terminated } \\
\text { at bedrock. }\end{array}$ \\
\hline CR003 & No Dig & - & - & - & - & Negative & $\begin{array}{l}\text { Other. Near road, } \\
\text { disturbed by road. }\end{array}$ \\
\hline CR004 & $0-15$ & $\begin{array}{l}10 Y R \\
5 / 3\end{array}$ & Brown & $\begin{array}{l}\text { Sandy } \\
\text { Loam }\end{array}$ & $>20 \%$ Gravels & Negative & $\begin{array}{l}\text { No cultural material } \\
\text { encountered. Terminated } \\
\text { at compact soil. }\end{array}$ \\
\hline CR005 & $0-40$ & $\begin{array}{l}10 Y R \\
5 / 3\end{array}$ & Brown & $\begin{array}{l}\text { Sandy } \\
\text { Loam }\end{array}$ & $>20 \%$ Gravels & Negative & $\begin{array}{l}\text { No cultural material } \\
\text { encountered. Terminated } \\
\text { at bedrock. }\end{array}$ \\
\hline CR006 & $0-35$ & $\begin{array}{l}10 Y R \\
5 / 3\end{array}$ & Brown & $\begin{array}{l}\text { Sandy } \\
\text { Loam }\end{array}$ & $>20 \%$ Gravels & Negative & $\begin{array}{l}\text { No cultural material } \\
\text { encountered. Terminated } \\
\text { at bedrock. }\end{array}$ \\
\hline CR007 & $0-35$ & $\begin{array}{l}10 Y R \\
5 / 3\end{array}$ & Brown & $\begin{array}{l}\text { Sandy } \\
\text { Loam }\end{array}$ & $>20 \%$ Gravels & Negative & $\begin{array}{l}\text { No cultural material } \\
\text { encountered. Terminated } \\
\text { at bedrock. }\end{array}$ \\
\hline CR008 & $0-35$ & $\begin{array}{l}10 Y R \\
5 / 3\end{array}$ & Brown & $\begin{array}{l}\text { Sandy } \\
\text { Loam }\end{array}$ & $>20 \%$ Gravels & Negative & $\begin{array}{l}\text { No cultural material } \\
\text { encountered. Terminated } \\
\text { at bedrock. }\end{array}$ \\
\hline CR009 & $0-55$ & $\begin{array}{l}10 Y R \\
5 / 3\end{array}$ & Brown & $\begin{array}{l}\text { Sandy } \\
\text { Loam }\end{array}$ & $>20 \%$ Gravels & Negative & $\begin{array}{l}\text { No cultural material } \\
\text { encountered. Terminated } \\
\text { at bedrock. }\end{array}$ \\
\hline CR010 & $0-35$ & $\begin{array}{l}10 Y R \\
5 / 3\end{array}$ & Brown & $\begin{array}{l}\text { Sandy } \\
\text { Loam }\end{array}$ & $>20 \%$ Gravels & Negative & $\begin{array}{l}\text { No cultural material } \\
\text { encountered. Terminated } \\
\text { at bedrock. }\end{array}$ \\
\hline CR011 & $0-35$ & $\begin{array}{l}7.5 \mathrm{YR} \\
5 / 6\end{array}$ & $\begin{array}{l}\text { Strong } \\
\text { Brown }\end{array}$ & Sand & $>20 \%$ Gravels & Negative & $\begin{array}{l}\text { No cultural material } \\
\text { encountered. Terminated } \\
\text { at bedrock. }\end{array}$ \\
\hline CR012 & $0-35$ & $\begin{array}{l}7.5 \mathrm{YR} \\
5 / 6\end{array}$ & $\begin{array}{l}\text { Strong } \\
\text { Brown }\end{array}$ & Sand & $>20 \%$ Gravels & Negative & $\begin{array}{l}\text { No cultural material } \\
\text { encountered. Terminated } \\
\text { at bedrock. }\end{array}$ \\
\hline CR013 & $0-40$ & $\begin{array}{l}7.5 Y R \\
5 / 6\end{array}$ & $\begin{array}{l}\text { Strong } \\
\text { Brown }\end{array}$ & Sand & $>20 \%$ Gravels & Negative & $\begin{array}{l}\text { No cultural material } \\
\text { encountered. Terminated } \\
\text { at bedrock. }\end{array}$ \\
\hline CR014 & $0-30$ & $\begin{array}{l}10 Y R \\
5 / 4\end{array}$ & $\begin{array}{l}\text { Yellowish } \\
\text { Brown }\end{array}$ & Sand & $\begin{array}{l}5-10 \% \text { Calcium } \\
\text { Carbonate }\end{array}$ & Negative & $\begin{array}{l}\text { No cultural material } \\
\text { encountered. Terminated } \\
\text { at compact soil. }\end{array}$ \\
\hline CR015 & $0-35$ & $\begin{array}{l}7.5 \mathrm{YR} \\
5 / 6\end{array}$ & $\begin{array}{l}\text { Strong } \\
\text { Brown }\end{array}$ & Sand & $>20 \%$ Gravels & Negative & $\begin{array}{l}\text { No cultural material } \\
\text { encountered. Terminated } \\
\text { at bedrock. }\end{array}$ \\
\hline CR016 & $0-30$ & $\begin{array}{l}10 Y R \\
5 / 3\end{array}$ & Brown & Sand & $\begin{array}{l}>20 \% \text { Calcium } \\
\text { Carbonate, Gravels }\end{array}$ & Negative & $\begin{array}{l}\text { No cultural material } \\
\text { encountered. Terminated } \\
\text { at impenetrable gravels. }\end{array}$ \\
\hline CR017 & $0-40$ & $\begin{array}{l}7.5 \mathrm{YR} \\
4 / 4\end{array}$ & Brown & Sand & $\begin{array}{l}5-10 \% \text { Calcium } \\
\text { Carbonate, Gravels }\end{array}$ & Negative & $\begin{array}{l}\text { No cultural material } \\
\text { encountered. Terminated } \\
\text { at compact soil. }\end{array}$ \\
\hline CR018 & $0-20$ & $\begin{array}{l}7.5 Y R \\
4 / 4\end{array}$ & Brown & Sand & $\begin{array}{l}5-10 \% \text { Calcium } \\
\text { Carbonate, Gravels }\end{array}$ & Negative & $\begin{array}{l}\text { No cultural material } \\
\text { encountered. Terminated } \\
\text { at bedrock. }\end{array}$ \\
\hline
\end{tabular}




\begin{tabular}{|c|c|c|c|c|c|c|c|}
\hline $\begin{array}{l}\text { STP } \\
\text { No. }\end{array}$ & $\begin{array}{l}\text { Depth } \\
\text { (cmbs) }\end{array}$ & Munsell & Soil Color & $\begin{array}{l}\text { Soil } \\
\text { Texture }\end{array}$ & Inclusions & $\begin{array}{l}\text { Positive/ } \\
\text { Negative }\end{array}$ & $\begin{array}{l}\text { Comments/ } \\
\text { Reason for Termination }\end{array}$ \\
\hline CR019 & $0-40$ & $\begin{array}{l}7.5 \mathrm{YR} \\
4 / 4\end{array}$ & Brown & Sand & $\begin{array}{l}5-10 \% \text { Calcium } \\
\text { Carbonate, Gravels }\end{array}$ & Negative & $\begin{array}{l}\text { No cultural material } \\
\text { encountered. Terminated } \\
\text { at compact soil. }\end{array}$ \\
\hline CR020 & $0-40$ & $\begin{array}{l}7.5 Y R \\
4 / 4\end{array}$ & Brown & Sand & $\begin{array}{l}5-10 \% \text { Calcium } \\
\text { Carbonate, Gravels }\end{array}$ & Negative & $\begin{array}{l}\text { No cultural material } \\
\text { encountered. Terminated } \\
\text { at compact soil. }\end{array}$ \\
\hline CR021 & $0-40$ & $\begin{array}{l}7.5 \mathrm{YR} \\
4 / 4\end{array}$ & Brown & Sand & $\begin{array}{l}\text { 5-10\% Calcium } \\
\text { Carbonate, Gravels }\end{array}$ & Negative & $\begin{array}{l}\text { No cultural material } \\
\text { encountered. Terminated } \\
\text { at compact soil. }\end{array}$ \\
\hline CR022 & $0-40$ & $\begin{array}{l}7.5 Y R \\
4 / 4\end{array}$ & Brown & Sand & $\begin{array}{l}\text { 5-10\% Calcium } \\
\text { Carbonate, Gravels }\end{array}$ & Negative & $\begin{array}{l}\text { No cultural material } \\
\text { encountered. Terminated } \\
\text { at compact soil. }\end{array}$ \\
\hline CR023 & $0-40$ & $\begin{array}{l}7.5 \mathrm{YR} \\
4 / 4\end{array}$ & Brown & Sand & $\begin{array}{l}\text { 5-10\% Calcium } \\
\text { Carbonate, Gravels }\end{array}$ & Negative & $\begin{array}{l}\text { No cultural material } \\
\text { encountered. Terminated } \\
\text { at compact soil. }\end{array}$ \\
\hline CR024 & $0-20$ & $\begin{array}{l}7.5 \mathrm{YR} \\
4 / 4\end{array}$ & Brown & Sand & $\begin{array}{l}5-10 \% \text { Calcium } \\
\text { Carbonate, Gravels }\end{array}$ & Negative & $\begin{array}{l}\text { No cultural material } \\
\text { encountered. Terminated } \\
\text { at bedrock. }\end{array}$ \\
\hline CR025 & $0-50$ & $\begin{array}{l}7.5 \mathrm{YR} \\
4 / 4\end{array}$ & Brown & Sand & $\begin{array}{l}5-10 \% \text { Calcium } \\
\text { Carbonate, Gravels }\end{array}$ & Negative & $\begin{array}{l}\text { No cultural material } \\
\text { encountered. Terminated } \\
\text { at compact soil. }\end{array}$ \\
\hline CR026 & $0-50$ & $\begin{array}{l}7.5 \mathrm{YR} \\
4 / 4\end{array}$ & Brown & Sand & $\begin{array}{l}\text { 5-10\% Calcium } \\
\text { Carbonate, Gravels }\end{array}$ & Negative & $\begin{array}{l}\text { No cultural material } \\
\text { encountered. Terminated } \\
\text { at compact soil. }\end{array}$ \\
\hline CR027 & $0-40$ & $\begin{array}{l}7.5 \mathrm{YR} \\
4 / 4\end{array}$ & Brown & Sand & $\begin{array}{l}5-10 \% \text { Calcium } \\
\text { Carbonate, Gravels }\end{array}$ & Negative & $\begin{array}{l}\text { No cultural material } \\
\text { encountered. Terminated } \\
\text { at compact soil. }\end{array}$ \\
\hline CR028 & $0-40$ & $\begin{array}{l}7.5 \mathrm{YR} \\
4 / 4\end{array}$ & Brown & Sand & $\begin{array}{l}5-10 \% \text { Calcium } \\
\text { Carbonate, Gravels }\end{array}$ & Negative & $\begin{array}{l}\text { No cultural material } \\
\text { encountered. Terminated } \\
\text { at compact soil. }\end{array}$ \\
\hline CR029 & $0-40$ & $\begin{array}{l}7.5 \mathrm{YR} \\
4 / 4\end{array}$ & Brown & Sand & $\begin{array}{l}\text { 5-10\% Calcium } \\
\text { Carbonate, Gravels }\end{array}$ & Negative & $\begin{array}{l}\text { No cultural material } \\
\text { encountered. Terminated } \\
\text { at compact soil. }\end{array}$ \\
\hline CR030 & $0-40$ & $\begin{array}{l}7.5 Y R \\
4 / 4\end{array}$ & Brown & Sand & $\begin{array}{l}5-10 \% \text { Calcium } \\
\text { Carbonate, Gravels }\end{array}$ & Negative & $\begin{array}{l}\text { No cultural material } \\
\text { encountered. Terminated } \\
\text { at compact soil. }\end{array}$ \\
\hline CR031 & $0-40$ & $\begin{array}{l}7.5 \mathrm{YR} \\
4 / 4\end{array}$ & Brown & Sand & $\begin{array}{l}5-10 \% \text { Calcium } \\
\text { Carbonate, Gravels }\end{array}$ & Negative & $\begin{array}{l}\text { No cultural material } \\
\text { encountered. Terminated } \\
\text { at compact soil. }\end{array}$ \\
\hline CR032 & $0-40$ & $\begin{array}{l}7.5 \mathrm{YR} \\
4 / 4\end{array}$ & Brown & Sand & $\begin{array}{l}\text { 5-10\% Calcium } \\
\text { Carbonate, Gravels }\end{array}$ & Negative & $\begin{array}{l}\text { No cultural material } \\
\text { encountered. Terminated } \\
\text { at compact soil. }\end{array}$ \\
\hline CR033 & $0-40$ & $\begin{array}{l}7.5 \mathrm{YR} \\
4 / 4\end{array}$ & Brown & Sand & $\begin{array}{l}5-10 \% \text { Calcium } \\
\text { Carbonate, Gravels }\end{array}$ & Negative & $\begin{array}{l}\text { No cultural material } \\
\text { encountered. Terminated } \\
\text { at compact soil. }\end{array}$ \\
\hline CR034 & $0-40$ & $\begin{array}{l}7.5 \mathrm{YR} \\
4 / 4\end{array}$ & Brown & Sand & $\begin{array}{l}\text { 5-10\% Calcium } \\
\text { Carbonate, Gravels }\end{array}$ & Negative & $\begin{array}{l}\text { No cultural material } \\
\text { encountered. Terminated } \\
\text { at compact soil. }\end{array}$ \\
\hline CR035 & $0-40$ & $\begin{array}{l}7.5 \mathrm{YR} \\
4 / 4\end{array}$ & Brown & Sand & $\begin{array}{l}5-10 \% \text { Calcium } \\
\text { Carbonate, Gravels }\end{array}$ & Negative & $\begin{array}{l}\text { No cultural material } \\
\text { encountered. Terminated } \\
\text { at compact soil. }\end{array}$ \\
\hline
\end{tabular}




\begin{tabular}{|c|c|c|c|c|c|c|c|}
\hline $\begin{array}{l}\text { STP } \\
\text { No. }\end{array}$ & $\begin{array}{l}\text { Depth } \\
\text { (cmbs) }\end{array}$ & Munsell & Soil Color & $\begin{array}{l}\text { Soil } \\
\text { Texture }\end{array}$ & Inclusions & $\begin{array}{l}\text { Positive/ } \\
\text { Negative }\end{array}$ & $\begin{array}{l}\text { Comments/ } \\
\text { Reason for Termination }\end{array}$ \\
\hline CR036 & $0-40$ & $\begin{array}{l}7.5 \mathrm{YR} \\
4 / 4\end{array}$ & Brown & Sand & $\begin{array}{l}5-10 \% \text { Calcium } \\
\text { Carbonate, Gravels }\end{array}$ & Negative & $\begin{array}{l}\text { No cultural material } \\
\text { encountered. Terminated } \\
\text { at compact soil. }\end{array}$ \\
\hline CR037 & $0-40$ & $\begin{array}{l}7.5 \mathrm{YR} \\
4 / 4\end{array}$ & Brown & Sand & $\begin{array}{l}5-10 \% \text { Calcium } \\
\text { Carbonate, Gravels }\end{array}$ & Negative & $\begin{array}{l}\text { No cultural material } \\
\text { encountered. Terminated } \\
\text { at compact soil. }\end{array}$ \\
\hline CR038 & $0-40$ & $\begin{array}{l}7.5 \mathrm{YR} \\
4 / 4\end{array}$ & Brown & Sand & $\begin{array}{l}5-10 \% \text { Calcium } \\
\text { Carbonate, Gravels }\end{array}$ & Negative & $\begin{array}{l}\text { No cultural material } \\
\text { encountered. Terminated } \\
\text { at compact soil. }\end{array}$ \\
\hline CR039 & $0-40$ & $\begin{array}{l}7.5 \mathrm{YR} \\
4 / 4\end{array}$ & Brown & Sand & $\begin{array}{l}5-10 \% \text { Calcium } \\
\text { Carbonate, Gravels }\end{array}$ & Negative & $\begin{array}{l}\text { No cultural material } \\
\text { encountered. Terminated } \\
\text { at compact soil. }\end{array}$ \\
\hline CR040 & $0-50$ & $\begin{array}{l}7.5 \mathrm{YR} \\
4 / 4\end{array}$ & Brown & Sand & $\begin{array}{l}5-10 \% \text { Calcium } \\
\text { Carbonate, Gravels }\end{array}$ & Negative & $\begin{array}{l}\text { No cultural material } \\
\text { encountered. Terminated } \\
\text { at compact soil. }\end{array}$ \\
\hline CR041 & $0-40$ & $\begin{array}{l}7.5 \mathrm{YR} \\
4 / 4\end{array}$ & Brown & Sand & $\begin{array}{l}5-10 \% \text { Calcium } \\
\text { Carbonate, Gravels }\end{array}$ & Negative & $\begin{array}{l}\text { No cultural material } \\
\text { encountered. Terminated } \\
\text { at compact soil. }\end{array}$ \\
\hline CR042 & $0-40$ & $\begin{array}{l}7.5 Y R \\
4 / 4\end{array}$ & Brown & Sand & $\begin{array}{l}5-10 \% \text { Calcium } \\
\text { Carbonate, Gravels }\end{array}$ & Negative & $\begin{array}{l}\text { No cultural material } \\
\text { encountered. Terminated } \\
\text { at compact soil. }\end{array}$ \\
\hline CR043 & $0-40$ & $\begin{array}{l}7.5 \mathrm{YR} \\
4 / 4\end{array}$ & Brown & Sand & $\begin{array}{l}5-10 \% \text { Calcium } \\
\text { Carbonate, Gravels }\end{array}$ & Negative & $\begin{array}{l}\text { No cultural material } \\
\text { encountered. Terminated } \\
\text { at compact soil. }\end{array}$ \\
\hline CR044 & $0-40$ & $\begin{array}{l}7.5 \mathrm{YR} \\
4 / 4\end{array}$ & Brown & Sand & $\begin{array}{l}5-10 \% \text { Calcium } \\
\text { Carbonate, Gravels }\end{array}$ & Negative & $\begin{array}{l}\text { No cultural material } \\
\text { encountered. Terminated } \\
\text { at compact soil. }\end{array}$ \\
\hline CR045 & $0-40$ & $\begin{array}{l}7.5 \mathrm{YR} \\
4 / 4\end{array}$ & Brown & Sand & $\begin{array}{l}5-10 \% \text { Calcium } \\
\text { Carbonate, Gravels }\end{array}$ & Negative & $\begin{array}{l}\text { No cultural material } \\
\text { encountered. Terminated } \\
\text { at compact soil. }\end{array}$ \\
\hline CR046 & $0-40$ & $\begin{array}{l}7.5 \mathrm{YR} \\
4 / 4\end{array}$ & Brown & Sand & $\begin{array}{l}5-10 \% \text { Calcium } \\
\text { Carbonate, Gravels }\end{array}$ & Negative & $\begin{array}{l}\text { No cultural material } \\
\text { encountered. Terminated } \\
\text { at compact soil. }\end{array}$ \\
\hline CR047 & $0-35$ & $\begin{array}{l}7.5 \mathrm{YR} \\
4 / 4\end{array}$ & Brown & $\begin{array}{l}\text { Sandy } \\
\text { Loam }\end{array}$ & $\begin{array}{l}\text { Calcium Carbonate, } \\
\text { Gravels, Large Rock } \\
\text { Frags, Mottles }\end{array}$ & Negative & $\begin{array}{l}\text { No cultural material } \\
\text { encountered. Terminated } \\
\text { at compact soil. }\end{array}$ \\
\hline CR048 & $0-40$ & $\begin{array}{l}7.5 \mathrm{YR} \\
4 / 4\end{array}$ & Brown & Sand & $\begin{array}{l}5-10 \% \text { Calcium } \\
\text { Carbonate, Gravels }\end{array}$ & Negative & $\begin{array}{l}\text { No cultural material } \\
\text { encountered. Terminated } \\
\text { at compact soil. }\end{array}$ \\
\hline CR049 & $0-40$ & $\begin{array}{l}7.5 \mathrm{YR} \\
4 / 4\end{array}$ & Brown & Sand & $\begin{array}{l}5-10 \% \text { Calcium } \\
\text { Carbonate, Gravels }\end{array}$ & Negative & $\begin{array}{l}\text { No cultural material } \\
\text { encountered. Terminated } \\
\text { at compact soil. }\end{array}$ \\
\hline CR050 & $0-55$ & $\begin{array}{l}7.5 Y R \\
4 / 4\end{array}$ & Brown & Sand & $\begin{array}{l}5-10 \% \text { Calcium } \\
\text { Carbonate, Gravels }\end{array}$ & Negative & $\begin{array}{l}\text { No cultural material } \\
\text { encountered. Terminated } \\
\text { at compact soil. }\end{array}$ \\
\hline CR051 & $0-40$ & $\begin{array}{l}7.5 \mathrm{YR} \\
4 / 4\end{array}$ & Brown & Sand & $\begin{array}{l}5-10 \% \text { Calcium } \\
\text { Carbonate, Gravels }\end{array}$ & Negative & $\begin{array}{l}\text { No cultural material } \\
\text { encountered. Terminated } \\
\text { at compact soil. }\end{array}$ \\
\hline CR052 & $0-50$ & $\begin{array}{l}7.5 Y R \\
4 / 4\end{array}$ & Brown & $\begin{array}{l}\text { Sandy } \\
\text { Loam }\end{array}$ & - & Negative & $\begin{array}{l}\text { No cultural material } \\
\text { encountered. Terminated } \\
\text { at compact soil. }\end{array}$ \\
\hline
\end{tabular}




\begin{tabular}{|c|c|c|c|c|c|c|c|}
\hline $\begin{array}{l}\text { STP } \\
\text { No. }\end{array}$ & $\begin{array}{l}\text { Depth } \\
\text { (cmbs) }\end{array}$ & Munsell & Soil Color & $\begin{array}{l}\text { Soil } \\
\text { Texture }\end{array}$ & Inclusions & $\begin{array}{l}\text { Positive/ } \\
\text { Negative }\end{array}$ & $\begin{array}{l}\text { Comments/ } \\
\text { Reason for Termination }\end{array}$ \\
\hline CR053 & $0-40$ & $\begin{array}{l}7.5 \mathrm{YR} \\
4 / 4\end{array}$ & Brown & $\begin{array}{l}\text { Sandy } \\
\text { Loam }\end{array}$ & - & Negative & $\begin{array}{l}\text { No cultural material } \\
\text { encountered. Terminated } \\
\text { at compact soil. }\end{array}$ \\
\hline CR054 & $0-50$ & $\begin{array}{l}7.5 \mathrm{YR} \\
4 / 4\end{array}$ & Brown & $\begin{array}{l}\text { Sandy } \\
\text { Loam }\end{array}$ & - & Negative & $\begin{array}{l}\text { No cultural material } \\
\text { encountered. Terminated } \\
\text { at compact soil. }\end{array}$ \\
\hline CR055 & $0-50$ & $\begin{array}{l}7.5 Y R \\
4 / 4\end{array}$ & Brown & $\begin{array}{l}\text { Sandy } \\
\text { Loam }\end{array}$ & - & Negative & $\begin{array}{l}\text { No cultural material } \\
\text { encountered. Terminated } \\
\text { at compact soil. }\end{array}$ \\
\hline CR056 & $0-50$ & $\begin{array}{l}7.5 Y R \\
4 / 4\end{array}$ & Brown & $\begin{array}{l}\text { Sandy } \\
\text { Loam }\end{array}$ & - & Negative & $\begin{array}{l}\text { No cultural material } \\
\text { encountered. Terminated } \\
\text { at compact soil. }\end{array}$ \\
\hline CR057 & $0-50$ & $\begin{array}{l}7.5 Y R \\
4 / 4\end{array}$ & Brown & $\begin{array}{l}\text { Sandy } \\
\text { Loam }\end{array}$ & - & Negative & $\begin{array}{l}\text { No cultural material } \\
\text { encountered. Terminated } \\
\text { at compact soil. }\end{array}$ \\
\hline CR058 & $0-50$ & $\begin{array}{l}7.5 Y R \\
4 / 4\end{array}$ & Brown & $\begin{array}{l}\text { Sandy } \\
\text { Loam }\end{array}$ & - & Negative & $\begin{array}{l}\text { No cultural material } \\
\text { encountered. Terminated } \\
\text { at compact soil. }\end{array}$ \\
\hline CR059 & $0-50$ & $\begin{array}{l}7.5 Y R \\
4 / 4\end{array}$ & Brown & $\begin{array}{l}\text { Sandy } \\
\text { Loam }\end{array}$ & - & Negative & $\begin{array}{l}\text { No cultural material } \\
\text { encountered. Terminated } \\
\text { at compact soil. }\end{array}$ \\
\hline CR060 & $0-50$ & $\begin{array}{l}7.5 Y R \\
4 / 4\end{array}$ & Brown & $\begin{array}{l}\text { Sandy } \\
\text { Loam }\end{array}$ & - & Negative & $\begin{array}{l}\text { No cultural material } \\
\text { encountered. Terminated } \\
\text { at compact soil. }\end{array}$ \\
\hline CR061 & $0-45$ & $\begin{array}{l}7.5 \mathrm{YR} \\
4 / 4\end{array}$ & Brown & $\begin{array}{l}\text { Sandy } \\
\text { Loam }\end{array}$ & - & Negative & $\begin{array}{l}\text { No cultural material } \\
\text { encountered. Terminated } \\
\text { at compact soil. }\end{array}$ \\
\hline CR062 & $0-50$ & $\begin{array}{l}7.5 Y R \\
4 / 4\end{array}$ & Brown & $\begin{array}{l}\text { Sandy } \\
\text { Loam }\end{array}$ & - & Negative & $\begin{array}{l}\text { No cultural material } \\
\text { encountered. Terminated } \\
\text { at compact soil. }\end{array}$ \\
\hline CR063 & $0-50$ & $\begin{array}{l}7.5 \mathrm{YR} \\
4 / 4\end{array}$ & Brown & $\begin{array}{l}\text { Sandy } \\
\text { Loam }\end{array}$ & - & Negative & $\begin{array}{l}\text { No cultural material } \\
\text { encountered. Terminated } \\
\text { at compact soil. }\end{array}$ \\
\hline CR064 & $0-50$ & $\begin{array}{l}7.5 \mathrm{YR} \\
4 / 4\end{array}$ & Brown & $\begin{array}{l}\text { Sandy } \\
\text { Loam }\end{array}$ & - & Negative & $\begin{array}{l}\text { No cultural material } \\
\text { encountered. Terminated } \\
\text { at compact soil. }\end{array}$ \\
\hline CR065 & $0-50$ & $\begin{array}{l}7.5 \mathrm{YR} \\
4 / 4\end{array}$ & Brown & $\begin{array}{l}\text { Sandy } \\
\text { Loam }\end{array}$ & - & Negative & $\begin{array}{l}\text { No cultural material } \\
\text { encountered. Terminated } \\
\text { at compact soil. }\end{array}$ \\
\hline CR066 & $0-50$ & $\begin{array}{l}7.5 \mathrm{YR} \\
4 / 4\end{array}$ & Brown & $\begin{array}{l}\text { Sandy } \\
\text { Loam }\end{array}$ & - & Negative & $\begin{array}{l}\text { No cultural material } \\
\text { encountered. Terminated } \\
\text { at compact soil. }\end{array}$ \\
\hline CR067 & $0-50$ & $\begin{array}{l}7.5 Y R \\
4 / 4\end{array}$ & Brown & $\begin{array}{l}\text { Sandy } \\
\text { Loam }\end{array}$ & - & Negative & $\begin{array}{l}\text { No cultural material } \\
\text { encountered. Terminated } \\
\text { at compact soil. }\end{array}$ \\
\hline CR068 & $0-55$ & $\begin{array}{l}7.5 \mathrm{YR} \\
4 / 4\end{array}$ & Brown & $\begin{array}{l}\text { Sandy } \\
\text { Loam }\end{array}$ & $\begin{array}{l}1-5 \% \text { Calcium } \\
\text { Carbonate, Gravels }\end{array}$ & Negative & $\begin{array}{l}\text { No cultural material } \\
\text { encountered. Terminated } \\
\text { at compact soil. }\end{array}$ \\
\hline CR069 & $0-45$ & $\begin{array}{l}7.5 \mathrm{YR} \\
4 / 4\end{array}$ & Brown & $\begin{array}{l}\text { Sandy } \\
\text { Loam }\end{array}$ & $\begin{array}{l}\text { 1-5\% Calcium } \\
\text { Carbonate, Gravels }\end{array}$ & Negative & $\begin{array}{l}\text { No cultural material } \\
\text { encountered. Terminated } \\
\text { at compact soil. }\end{array}$ \\
\hline
\end{tabular}




\begin{tabular}{|c|c|c|c|c|c|c|c|}
\hline $\begin{array}{l}\text { STP } \\
\text { No. }\end{array}$ & $\begin{array}{l}\text { Depth } \\
\text { (cmbs) }\end{array}$ & Munsell & Soil Color & $\begin{array}{l}\text { Soil } \\
\text { Texture }\end{array}$ & Inclusions & $\begin{array}{l}\text { Positive/ } \\
\text { Negative }\end{array}$ & $\begin{array}{l}\text { Comments/ } \\
\text { Reason for Termination }\end{array}$ \\
\hline CR070 & $0-55$ & $\begin{array}{l}7.5 \mathrm{YR} \\
4 / 4\end{array}$ & Brown & $\begin{array}{l}\text { Sandy } \\
\text { Loam }\end{array}$ & $\begin{array}{l}1-5 \% \text { Calcium } \\
\text { Carbonate, Gravels }\end{array}$ & Negative & $\begin{array}{l}\text { No cultural material } \\
\text { encountered. Terminated } \\
\text { at compact soil. }\end{array}$ \\
\hline CR071 & $0-45$ & $\begin{array}{l}7.5 \mathrm{YR} \\
4 / 4\end{array}$ & Brown & $\begin{array}{l}\text { Sandy } \\
\text { Loam }\end{array}$ & $\begin{array}{l}\text { 1-5\% Calcium } \\
\text { Carbonate, Gravels }\end{array}$ & Negative & $\begin{array}{l}\text { No cultural material } \\
\text { encountered. Terminated } \\
\text { at compact soil. }\end{array}$ \\
\hline CR072 & $0-55$ & $\begin{array}{l}7.5 \mathrm{YR} \\
4 / 4\end{array}$ & Brown & $\begin{array}{l}\text { Sandy } \\
\text { Loam }\end{array}$ & $\begin{array}{l}\text { 1-5\% Calcium } \\
\text { Carbonate, Gravels }\end{array}$ & Negative & $\begin{array}{l}\text { No cultural material } \\
\text { encountered. Terminated } \\
\text { at compact soil. }\end{array}$ \\
\hline CR073 & $0-40$ & $\begin{array}{l}7.5 \mathrm{YR} \\
4 / 4\end{array}$ & Brown & $\begin{array}{l}\text { Sandy } \\
\text { Loam }\end{array}$ & $\begin{array}{l}1-5 \% \text { Calcium } \\
\text { Carbonate, Gravels }\end{array}$ & Negative & $\begin{array}{l}\text { No cultural material } \\
\text { encountered. Terminated } \\
\text { at compact soil. }\end{array}$ \\
\hline CR074 & $0-40$ & $\begin{array}{l}7.5 \mathrm{YR} \\
4 / 4\end{array}$ & Brown & $\begin{array}{l}\text { Sandy } \\
\text { Loam }\end{array}$ & $\begin{array}{l}1-5 \% \text { Calcium } \\
\text { Carbonate, Gravels }\end{array}$ & Negative & $\begin{array}{l}\text { No cultural material } \\
\text { encountered. Terminated } \\
\text { at compact soil. }\end{array}$ \\
\hline CR075 & $0-55$ & $\begin{array}{l}7.5 \mathrm{YR} \\
4 / 4\end{array}$ & Brown & $\begin{array}{l}\text { Sandy } \\
\text { Loam }\end{array}$ & $\begin{array}{l}1-5 \% \text { Calcium } \\
\text { Carbonate, Gravels }\end{array}$ & Negative & $\begin{array}{l}\text { No cultural material } \\
\text { encountered. Terminated } \\
\text { at compact soil. }\end{array}$ \\
\hline CR076 & $0-50$ & $\begin{array}{l}7.5 Y R \\
4 / 6\end{array}$ & $\begin{array}{l}\text { Strong } \\
\text { Brown }\end{array}$ & $\begin{array}{l}\text { Sandy } \\
\text { Loam }\end{array}$ & - & Negative & $\begin{array}{l}\text { No cultural material } \\
\text { encountered. Terminated } \\
\text { at compact soil. }\end{array}$ \\
\hline CR077 & $0-50$ & $\begin{array}{l}7.5 \mathrm{YR} \\
4 / 6\end{array}$ & $\begin{array}{l}\text { Strong } \\
\text { Brown }\end{array}$ & $\begin{array}{l}\text { Sandy } \\
\text { Loam }\end{array}$ & - & Negative & $\begin{array}{l}\text { No cultural material } \\
\text { encountered. Terminated } \\
\text { at compact soil. }\end{array}$ \\
\hline CR078 & $0-45$ & $5 Y R \quad 4 / 6$ & $\begin{array}{l}\text { Yellowish } \\
\text { Red }\end{array}$ & Sand & $1-5 \%$ Gravels & Negative & $\begin{array}{l}\text { No cultural material } \\
\text { encountered. Terminated } \\
\text { at compact soil. }\end{array}$ \\
\hline CR079 & $0-45$ & 5YR 4/6 & $\begin{array}{l}\text { Yellowish } \\
\text { Red }\end{array}$ & Sand & 1-5\% Gravels & Negative & $\begin{array}{l}\text { No cultural material } \\
\text { encountered. Terminated } \\
\text { at compact soil. }\end{array}$ \\
\hline CR080 & $0-30$ & 5YR 4/6 & $\begin{array}{l}\text { Yellowish } \\
\text { Red }\end{array}$ & Sand & 1-5\% Gravels & Negative & $\begin{array}{l}\text { No cultural material } \\
\text { encountered. Terminated } \\
\text { at compact soil. }\end{array}$ \\
\hline CR081 & $0-25$ & $\begin{array}{l}7.5 \mathrm{YR} \\
4 / 4\end{array}$ & Brown & $\begin{array}{l}\text { Sandy } \\
\text { Loam }\end{array}$ & $\begin{array}{l}>20 \% \text { Calcium } \\
\text { Carbonate, Gravels }\end{array}$ & Negative & $\begin{array}{l}\text { No cultural material } \\
\text { encountered. Terminated } \\
\text { at bedrock. }\end{array}$ \\
\hline CR082 & $0-50$ & $\begin{array}{l}7.5 Y R \\
4 / 4\end{array}$ & Brown & $\begin{array}{l}\text { Sandy } \\
\text { Loam }\end{array}$ & - & Negative & $\begin{array}{l}\text { No cultural material } \\
\text { encountered. Terminated } \\
\text { at compact soil. }\end{array}$ \\
\hline CR083 & $0-50$ & $\begin{array}{l}7.5 \mathrm{YR} \\
4 / 4\end{array}$ & Brown & $\begin{array}{l}\text { Sandy } \\
\text { Loam }\end{array}$ & - & Negative & $\begin{array}{l}\text { No cultural material } \\
\text { encountered. Terminated } \\
\text { at compact soil. }\end{array}$ \\
\hline \multirow[b]{2}{*}{ CR084 } & $0-30$ & $\begin{array}{l}7.5 \mathrm{YR} \\
4 / 4\end{array}$ & Brown & $\begin{array}{l}\text { Loamy } \\
\text { Sand }\end{array}$ & - & Negative & $\begin{array}{l}\text { No cultural material } \\
\text { encountered. }\end{array}$ \\
\hline & $30-100$ & 5YR 5/6 & $\begin{array}{l}\text { Yellowish } \\
\text { Red }\end{array}$ & Sand & 1-5\% Pebbles & Negative & $\begin{array}{l}\text { No cultural material } \\
\text { encountered. Terminated } \\
\text { at depth. }\end{array}$ \\
\hline \multirow[b]{2}{*}{ CR085 } & $0-30$ & $\begin{array}{l}7.5 \mathrm{YR} \\
4 / 4\end{array}$ & Brown & $\begin{array}{l}\text { Loamy } \\
\text { Sand }\end{array}$ & - & Negative & $\begin{array}{l}\text { No cultural material } \\
\text { encountered. }\end{array}$ \\
\hline & $30-100$ & 5YR 5/6 & $\begin{array}{l}\text { Yellowish } \\
\text { Red }\end{array}$ & Sand & 1-5\% Pebbles & Negative & $\begin{array}{l}\text { No cultural material } \\
\text { encountered. Terminated } \\
\text { at depth. }\end{array}$ \\
\hline
\end{tabular}




\begin{tabular}{|c|c|c|c|c|c|c|c|}
\hline $\begin{array}{l}\text { STP } \\
\text { No. }\end{array}$ & $\begin{array}{l}\text { Depth } \\
\text { (cmbs) }\end{array}$ & Munsell & Soil Color & $\begin{array}{l}\text { Soil } \\
\text { Texture }\end{array}$ & Inclusions & $\begin{array}{l}\text { Positive/ } \\
\text { Negative }\end{array}$ & $\begin{array}{l}\text { Comments/ } \\
\text { Reason for Termination }\end{array}$ \\
\hline \multirow[b]{2}{*}{ CR086 } & $0-30$ & $\begin{array}{l}7.5 \mathrm{YR} \\
4 / 4\end{array}$ & Brown & $\begin{array}{l}\text { Loamy } \\
\text { Sand }\end{array}$ & - & Negative & $\begin{array}{l}\text { No cultural material } \\
\text { encountered. }\end{array}$ \\
\hline & $30-100$ & 5YR 5/6 & $\begin{array}{l}\text { Yellowish } \\
\text { Red }\end{array}$ & Sand & 1-5\% Pebbles & Negative & $\begin{array}{l}\text { No cultural material } \\
\text { encountered. Terminated } \\
\text { at depth. }\end{array}$ \\
\hline \multirow[b]{2}{*}{ CR087 } & $0-5$ & $\begin{array}{l}7.5 \mathrm{YR} \\
4 / 4\end{array}$ & Brown & $\begin{array}{l}\text { Loamy } \\
\text { Sand }\end{array}$ & - & Negative & $\begin{array}{l}\text { No cultural material } \\
\text { encountered. }\end{array}$ \\
\hline & $5-100$ & 5YR 5/6 & $\begin{array}{l}\text { Yellowish } \\
\text { Red }\end{array}$ & Sand & 1-5\% Pebbles & Negative & $\begin{array}{l}\text { No cultural material } \\
\text { encountered. Terminated } \\
\text { at depth. }\end{array}$ \\
\hline \multirow[b]{2}{*}{ CR088 } & $0-30$ & $\begin{array}{l}7.5 \mathrm{YR} \\
4 / 4\end{array}$ & Brown & $\begin{array}{l}\text { Loamy } \\
\text { Sand }\end{array}$ & - & Negative & $\begin{array}{l}\text { No cultural material } \\
\text { encountered. }\end{array}$ \\
\hline & $30-100$ & 5YR 5/6 & $\begin{array}{l}\text { Yellowish } \\
\text { Red }\end{array}$ & Sand & 1-5\% Pebbles & Negative & $\begin{array}{l}\text { No cultural material } \\
\text { encountered. Terminated } \\
\text { at depth. }\end{array}$ \\
\hline \multirow[b]{2}{*}{ CR089 } & $0-50$ & $\begin{array}{l}7.5 \mathrm{YR} \\
4 / 4\end{array}$ & Brown & $\begin{array}{l}\text { Loamy } \\
\text { Sand }\end{array}$ & - & Negative & $\begin{array}{l}\text { No cultural material } \\
\text { encountered. }\end{array}$ \\
\hline & $50-100$ & 5YR 5/6 & $\begin{array}{l}\text { Yellowish } \\
\text { Red }\end{array}$ & Sand & 1-5\% Pebbles & Negative & $\begin{array}{l}\text { No cultural material } \\
\text { encountered. Terminated } \\
\text { at depth. }\end{array}$ \\
\hline \multirow[b]{2}{*}{ CR090 } & $0-30$ & $\begin{array}{l}7.5 Y R \\
4 / 4\end{array}$ & Brown & $\begin{array}{l}\text { Loamy } \\
\text { Sand }\end{array}$ & - & Negative & $\begin{array}{l}\text { No cultural material } \\
\text { encountered. }\end{array}$ \\
\hline & $30-100$ & 5YR 5/6 & $\begin{array}{l}\text { Yellowish } \\
\text { Red }\end{array}$ & Sand & 1-5\% Pebbles & Negative & $\begin{array}{l}\text { No cultural material } \\
\text { encountered. Terminated } \\
\text { at depth. }\end{array}$ \\
\hline \multirow[b]{2}{*}{ CR091 } & $0-60$ & 5YR 4/6 & $\begin{array}{l}\text { Yellowish } \\
\text { Red }\end{array}$ & $\begin{array}{l}\text { Sandy } \\
\text { Clay }\end{array}$ & 1-5\% Pebbles & Negative & $\begin{array}{l}\text { No cultural material } \\
\text { encountered. }\end{array}$ \\
\hline & $60-70$ & $5 Y R 3 / 3$ & $\begin{array}{l}\text { Dark } \\
\text { Reddish } \\
\text { Brown }\end{array}$ & $\begin{array}{l}\text { Sandy } \\
\text { Clay } \\
\text { Loam }\end{array}$ & 1-5\% Pebbles & Negative & $\begin{array}{l}\text { No cultural material } \\
\text { encountered. Terminated } \\
\text { at basal clay. }\end{array}$ \\
\hline \multirow[b]{2}{*}{ CR092 } & $0-30$ & $\begin{array}{l}7.5 Y R \\
4 / 4\end{array}$ & Brown & $\begin{array}{l}\text { Loamy } \\
\text { Sand }\end{array}$ & - & Negative & $\begin{array}{l}\text { No cultural material } \\
\text { encountered. }\end{array}$ \\
\hline & $30-100$ & 5YR 5/6 & $\begin{array}{l}\text { Yellowish } \\
\text { Red }\end{array}$ & Sand & 1-5\% Pebbles & Negative & $\begin{array}{l}\text { No cultural material } \\
\text { encountered. Terminated } \\
\text { at depth. }\end{array}$ \\
\hline \multirow[b]{2}{*}{ CR093 } & $0-60$ & 5YR 5/8 & $\begin{array}{l}\text { Yellowish } \\
\text { Red }\end{array}$ & $\begin{array}{l}\text { Loamy } \\
\text { Sand }\end{array}$ & 1-5\% Pebbles & Negative & $\begin{array}{l}\text { No cultural material } \\
\text { encountered. }\end{array}$ \\
\hline & $60-70$ & 5YR 4/6 & $\begin{array}{l}\text { Yellowish } \\
\text { Red }\end{array}$ & $\begin{array}{l}\text { Sandy } \\
\text { Clay } \\
\text { Loam }\end{array}$ & - & Negative & $\begin{array}{l}\text { No cultural material } \\
\text { encountered. Terminated } \\
\text { at basal clay. }\end{array}$ \\
\hline CR094 & $0-40$ & 5YR 5/8 & $\begin{array}{l}\text { Yellowish } \\
\text { Red }\end{array}$ & $\begin{array}{l}\text { Loamy } \\
\text { Sand }\end{array}$ & 1-5\% Pebbles & Negative & $\begin{array}{l}\text { No cultural material } \\
\text { encountered. Terminated } \\
\text { at root impasse. }\end{array}$ \\
\hline \multirow[b]{2}{*}{ CR095 } & $0-60$ & 5YR 5/8 & $\begin{array}{l}\text { Yellowish } \\
\text { Red }\end{array}$ & $\begin{array}{l}\text { Loamy } \\
\text { Sand }\end{array}$ & 1-5\% Pebbles & Negative & $\begin{array}{l}\text { No cultural material } \\
\text { encountered. }\end{array}$ \\
\hline & $60-70$ & 5YR 4/6 & $\begin{array}{l}\text { Yellowish } \\
\text { Red }\end{array}$ & $\begin{array}{l}\text { Sandy } \\
\text { Clay } \\
\text { Loam }\end{array}$ & - & Negative & $\begin{array}{l}\text { No cultural material } \\
\text { encountered. Terminated } \\
\text { at basal clay. }\end{array}$ \\
\hline
\end{tabular}




\begin{tabular}{|c|c|c|c|c|c|c|c|}
\hline $\begin{array}{l}\text { STP } \\
\text { No. }\end{array}$ & $\begin{array}{l}\text { Depth } \\
\text { (cmbs) }\end{array}$ & Munsell & Soil Color & $\begin{array}{l}\text { Soil } \\
\text { Texture }\end{array}$ & Inclusions & $\begin{array}{l}\text { Positive/ } \\
\text { Negative }\end{array}$ & $\begin{array}{l}\text { Comments/ } \\
\text { Reason for Termination }\end{array}$ \\
\hline \multirow[b]{2}{*}{ CR096 } & $0-80$ & 5YR 5/8 & $\begin{array}{l}\text { Yellowish } \\
\text { Red }\end{array}$ & $\begin{array}{l}\text { Loamy } \\
\text { Sand }\end{array}$ & 1-5\% Pebbles & Negative & $\begin{array}{l}\text { No cultural material } \\
\text { encountered. }\end{array}$ \\
\hline & $80-90$ & 5YR 4/6 & $\begin{array}{l}\text { Yellowish } \\
\text { Red }\end{array}$ & $\begin{array}{l}\text { Sandy } \\
\text { Clay } \\
\text { Loam }\end{array}$ & - & Negative & $\begin{array}{l}\text { No cultural material } \\
\text { encountered. Terminated } \\
\text { at basal clay. }\end{array}$ \\
\hline \multirow[b]{2}{*}{ CR097 } & $0-60$ & 5YR 5/8 & $\begin{array}{l}\text { Yellowish } \\
\text { Red }\end{array}$ & $\begin{array}{l}\text { Loamy } \\
\text { Sand }\end{array}$ & 1-5\% Pebbles & Negative & $\begin{array}{l}\text { No cultural material } \\
\text { encountered. }\end{array}$ \\
\hline & $60-70$ & 5YR 4/6 & $\begin{array}{l}\text { Yellowish } \\
\text { Red }\end{array}$ & $\begin{array}{l}\text { Sandy } \\
\text { Clay } \\
\text { Loam }\end{array}$ & - & Negative & $\begin{array}{l}\text { No cultural material } \\
\text { encountered. Terminated } \\
\text { at basal clay. }\end{array}$ \\
\hline \multirow[b]{2}{*}{ CR098 } & $0-60$ & 5YR 5/8 & $\begin{array}{l}\text { Yellowish } \\
\text { Red }\end{array}$ & $\begin{array}{l}\text { Loamy } \\
\text { Sand }\end{array}$ & 1-5\% Pebbles & Negative & $\begin{array}{l}\text { No cultural material } \\
\text { encountered. }\end{array}$ \\
\hline & $60-70$ & 5YR 4/6 & $\begin{array}{l}\text { Yellowish } \\
\text { Red }\end{array}$ & $\begin{array}{l}\text { Sandy } \\
\text { Clay } \\
\text { Loam }\end{array}$ & - & Negative & $\begin{array}{l}\text { No cultural material } \\
\text { encountered. Terminated } \\
\text { at basal clay. }\end{array}$ \\
\hline \multirow[b]{2}{*}{ CR099 } & $0-60$ & 5YR 5/8 & $\begin{array}{l}\text { Yellowish } \\
\text { Red }\end{array}$ & $\begin{array}{l}\text { Loamy } \\
\text { Sand }\end{array}$ & 1-5\% Pebbles & Negative & $\begin{array}{l}\text { No cultural material } \\
\text { encountered. }\end{array}$ \\
\hline & $60-70$ & 5YR 4/6 & $\begin{array}{l}\text { Yellowish } \\
\text { Red }\end{array}$ & $\begin{array}{l}\text { Sandy } \\
\text { Clay } \\
\text { Loam }\end{array}$ & - & Negative & $\begin{array}{l}\text { No cultural material } \\
\text { encountered. Terminated } \\
\text { at basal clay. }\end{array}$ \\
\hline \multirow[b]{2}{*}{ CR100 } & $0-20$ & $\begin{array}{l}7.5 \mathrm{YR} \\
3 / 3\end{array}$ & Dark Brown & $\begin{array}{l}\text { Loamy } \\
\text { Sand }\end{array}$ & $10-20 \%$ Mottles & Negative & $\begin{array}{l}\text { No cultural material } \\
\text { encountered. }\end{array}$ \\
\hline & $20-35$ & 5YR 4/6 & $\begin{array}{l}\text { Yellowish } \\
\text { Red }\end{array}$ & $\begin{array}{l}\text { Sandy } \\
\text { Clay } \\
\text { Loam }\end{array}$ & - & Negative & $\begin{array}{l}\text { No cultural material } \\
\text { encountered. Terminated } \\
\text { at basal clay. }\end{array}$ \\
\hline \multirow[b]{2}{*}{ CR101 } & $0-60$ & 5YR 5/8 & $\begin{array}{l}\text { Yellowish } \\
\text { Red }\end{array}$ & $\begin{array}{l}\text { Loamy } \\
\text { Sand }\end{array}$ & 1-5\% Pebbles & Negative & $\begin{array}{l}\text { No cultural material } \\
\text { encountered. }\end{array}$ \\
\hline & $60-70$ & 5YR 4/6 & $\begin{array}{l}\text { Yellowish } \\
\text { Red }\end{array}$ & $\begin{array}{l}\text { Sandy } \\
\text { Clay } \\
\text { Loam }\end{array}$ & - & Negative & $\begin{array}{l}\text { No cultural material } \\
\text { encountered. Terminated } \\
\text { at basal clay. }\end{array}$ \\
\hline \multirow[b]{2}{*}{ CR102 } & $0-35$ & 5YR 5/8 & $\begin{array}{l}\text { Yellowish } \\
\text { Red }\end{array}$ & $\begin{array}{l}\text { Loamy } \\
\text { Sand }\end{array}$ & 1-5\% Pebbles & Negative & $\begin{array}{l}\text { No cultural material } \\
\text { encountered. }\end{array}$ \\
\hline & $35-45$ & 5YR 4/6 & $\begin{array}{l}\text { Yellowish } \\
\text { Red }\end{array}$ & $\begin{array}{l}\text { Sandy } \\
\text { Clay } \\
\text { Loam }\end{array}$ & - & Negative & $\begin{array}{l}\text { No cultural material } \\
\text { encountered. Terminated } \\
\text { at basal clay. }\end{array}$ \\
\hline \multirow[b]{2}{*}{ CR103 } & $0-30$ & 5YR 5/8 & $\begin{array}{l}\text { Yellowish } \\
\text { Red }\end{array}$ & $\begin{array}{l}\text { Loamy } \\
\text { Sand }\end{array}$ & 1-5\% Pebbles & Negative & $\begin{array}{l}\text { No cultural material } \\
\text { encountered. }\end{array}$ \\
\hline & $30-45$ & 5YR 4/6 & $\begin{array}{l}\text { Yellowish } \\
\text { Red }\end{array}$ & $\begin{array}{l}\text { Sandy } \\
\text { Clay } \\
\text { Loam }\end{array}$ & - & Negative & $\begin{array}{l}\text { No cultural material } \\
\text { encountered. Terminated } \\
\text { at basal clay. }\end{array}$ \\
\hline \multirow[b]{2}{*}{ CR104 } & $0-60$ & 5YR 5/8 & $\begin{array}{l}\text { Yellowish } \\
\text { Red }\end{array}$ & $\begin{array}{l}\text { Loamy } \\
\text { Sand }\end{array}$ & 1-5\% Pebbles & Negative & $\begin{array}{l}\text { No cultural material } \\
\text { encountered. }\end{array}$ \\
\hline & $60-70$ & 5YR 4/6 & $\begin{array}{l}\text { Yellowish } \\
\text { Red }\end{array}$ & $\begin{array}{l}\text { Sandy } \\
\text { Clay } \\
\text { Loam }\end{array}$ & - & Negative & $\begin{array}{l}\text { No cultural material } \\
\text { encountered. Terminated } \\
\text { at basal clay. }\end{array}$ \\
\hline \multirow[b]{2}{*}{ CR105 } & $0-50$ & 5YR 5/8 & $\begin{array}{l}\text { Yellowish } \\
\text { Red }\end{array}$ & $\begin{array}{l}\text { Loamy } \\
\text { Sand }\end{array}$ & 1-5\% Pebbles & Negative & $\begin{array}{l}\text { No cultural material } \\
\text { encountered. }\end{array}$ \\
\hline & $50-60$ & 5YR 4/6 & $\begin{array}{l}\text { Yellowish } \\
\text { Red }\end{array}$ & $\begin{array}{l}\text { Sandy } \\
\text { Clay } \\
\text { Loam }\end{array}$ & - & Negative & $\begin{array}{l}\text { No cultural material } \\
\text { encountered. Terminated } \\
\text { at basal clay. }\end{array}$ \\
\hline
\end{tabular}




\begin{tabular}{|c|c|c|c|c|c|c|c|}
\hline $\begin{array}{l}\text { STP } \\
\text { No. }\end{array}$ & $\begin{array}{l}\text { Depth } \\
\text { (cmbs) }\end{array}$ & Munsell & Soil Color & $\begin{array}{l}\text { Soil } \\
\text { Texture }\end{array}$ & Inclusions & $\begin{array}{l}\text { Positive/ } \\
\text { Negative }\end{array}$ & $\begin{array}{l}\text { Comments/ } \\
\text { Reason for Termination }\end{array}$ \\
\hline \multirow[b]{2}{*}{ CR106 } & $0-40$ & 5YR 5/8 & $\begin{array}{l}\text { Yellowish } \\
\text { Red }\end{array}$ & $\begin{array}{l}\text { Loamy } \\
\text { Sand }\end{array}$ & 1-5\% Pebbles & Negative & $\begin{array}{l}\text { No cultural material } \\
\text { encountered. }\end{array}$ \\
\hline & $40-50$ & 5YR 4/6 & $\begin{array}{l}\text { Yellowish } \\
\text { Red }\end{array}$ & $\begin{array}{l}\text { Sandy } \\
\text { Clay } \\
\text { Loam }\end{array}$ & - & Negative & $\begin{array}{l}\text { No cultural material } \\
\text { encountered. Terminated } \\
\text { at basal clay. }\end{array}$ \\
\hline \multirow[b]{2}{*}{ CR107 } & $0-40$ & 5YR 5/8 & $\begin{array}{l}\text { Yellowish } \\
\text { Red }\end{array}$ & $\begin{array}{l}\text { Loamy } \\
\text { Sand }\end{array}$ & 1-5\% Pebbles & Negative & $\begin{array}{l}\text { No cultural material } \\
\text { encountered. }\end{array}$ \\
\hline & $40-50$ & $5 Y R$ 4/6 & $\begin{array}{l}\text { Yellowish } \\
\text { Red }\end{array}$ & $\begin{array}{l}\text { Sandy } \\
\text { Clay } \\
\text { Loam }\end{array}$ & - & Negative & $\begin{array}{l}\text { No cultural material } \\
\text { encountered. Terminated } \\
\text { at basal clay. }\end{array}$ \\
\hline \multirow[b]{2}{*}{ CR108 } & $0-30$ & $\begin{array}{l}7.5 \mathrm{YR} \\
4 / 4\end{array}$ & Brown & $\begin{array}{l}\text { Sandy } \\
\text { Loam }\end{array}$ & - & Negative & $\begin{array}{l}\text { No cultural material } \\
\text { encountered. }\end{array}$ \\
\hline & $30-45$ & 5YR 4/4 & $\begin{array}{l}\text { Reddish } \\
\text { Brown }\end{array}$ & $\begin{array}{l}\text { Sandy } \\
\text { Clay } \\
\text { Loam }\end{array}$ & $>20 \%$ Mottles & Negative & $\begin{array}{l}\text { No cultural material } \\
\text { encountered. Terminated } \\
\text { at basal clay. }\end{array}$ \\
\hline \multirow[b]{2}{*}{ CR109 } & $0-30$ & $\begin{array}{l}7.5 \mathrm{YR} \\
4 / 4\end{array}$ & Brown & $\begin{array}{l}\text { Sandy } \\
\text { Loam }\end{array}$ & - & Negative & $\begin{array}{l}\text { No cultural material } \\
\text { encountered. }\end{array}$ \\
\hline & $30-45$ & 5YR 4/4 & $\begin{array}{l}\text { Reddish } \\
\text { Brown }\end{array}$ & $\begin{array}{l}\text { Sandy } \\
\text { Clay } \\
\text { Loam }\end{array}$ & $>20 \%$ Mottles & Negative & $\begin{array}{l}\text { No cultural material } \\
\text { encountered. Terminated } \\
\text { at basal clay. }\end{array}$ \\
\hline SS001 & $0-30$ & $\begin{array}{l}7.5 Y R \\
4 / 4\end{array}$ & Brown & $\begin{array}{l}\text { Sandy } \\
\text { Clay }\end{array}$ & $\begin{array}{l}>20 \% \text { Calcium } \\
\text { Carbonate, Gravels, } \\
\text { Pebbles }\end{array}$ & Negative & $\begin{array}{l}\text { No cultural material } \\
\text { encountered. Terminated } \\
\text { at compact soil. }\end{array}$ \\
\hline SS002 & $0-30$ & $\begin{array}{l}7.5 \mathrm{YR} \\
4 / 4\end{array}$ & Brown & $\begin{array}{l}\text { Sandy } \\
\text { Clay }\end{array}$ & $\begin{array}{l}>20 \% \text { Calcium } \\
\text { Carbonate, Gravels, } \\
\text { Pebbles }\end{array}$ & Negative & $\begin{array}{l}\text { No cultural material } \\
\text { encountered. Terminated } \\
\text { at compact soil. }\end{array}$ \\
\hline SS003 & $0-20$ & $\begin{array}{l}7.5 Y R \\
4 / 4\end{array}$ & Brown & $\begin{array}{l}\text { Sandy } \\
\text { Clay }\end{array}$ & $\begin{array}{l}>20 \% \text { Calcium } \\
\text { Carbonate, Gravels, } \\
\text { Pebbles }\end{array}$ & Negative & $\begin{array}{l}\text { No cultural material } \\
\text { encountered. Terminated } \\
\text { at compact soil. }\end{array}$ \\
\hline SS004 & $0-15$ & $\begin{array}{l}7.5 \mathrm{YR} \\
4 / 4\end{array}$ & Brown & $\begin{array}{l}\text { Sandy } \\
\text { Clay }\end{array}$ & $\begin{array}{l}>20 \% \text { Calcium } \\
\text { Carbonate, Gravels, } \\
\text { Pebbles }\end{array}$ & Negative & $\begin{array}{l}\text { No cultural material } \\
\text { encountered. Terminated } \\
\text { at compact soil. }\end{array}$ \\
\hline SS006 & $0-15$ & $\begin{array}{l}7.5 \mathrm{YR} \\
4 / 4\end{array}$ & Brown & $\begin{array}{l}\text { Sandy } \\
\text { Clay }\end{array}$ & $\begin{array}{l}>20 \% \text { Calcium } \\
\text { Carbonate, Gravels, } \\
\text { Pebbles }\end{array}$ & Negative & $\begin{array}{l}\text { No cultural material } \\
\text { encountered. Terminated } \\
\text { at compact soil. }\end{array}$ \\
\hline SS007 & $0-25$ & $\begin{array}{l}7.5 Y R \\
4 / 4\end{array}$ & Brown & $\begin{array}{l}\text { Sandy } \\
\text { Clay }\end{array}$ & $\begin{array}{l}>20 \% \text { Calcium } \\
\text { Carbonate, Gravels, } \\
\text { Pebbles }\end{array}$ & Negative & $\begin{array}{l}\text { No cultural material } \\
\text { encountered. Terminated } \\
\text { at compact soil. }\end{array}$ \\
\hline SS008 & $0-35$ & $\begin{array}{l}7.5 Y R \\
4 / 4\end{array}$ & Brown & $\begin{array}{l}\text { Sandy } \\
\text { Clay }\end{array}$ & $\begin{array}{l}>20 \% \text { Calcium } \\
\text { Carbonate, Gravels, } \\
\text { Pebbles }\end{array}$ & Negative & $\begin{array}{l}\text { No cultural material } \\
\text { encountered. Terminated } \\
\text { at compact soil. }\end{array}$ \\
\hline SS009 & $0-30$ & $\begin{array}{l}7.5 Y R \\
4 / 4\end{array}$ & Brown & $\begin{array}{l}\text { Sandy } \\
\text { Clay }\end{array}$ & $\begin{array}{l}>20 \% \text { Calcium } \\
\text { Carbonate, Gravels, } \\
\text { Pebbles }\end{array}$ & Negative & $\begin{array}{l}\text { No cultural material } \\
\text { encountered. Terminated } \\
\text { at compact soil. }\end{array}$ \\
\hline SS010 & $0-30$ & $\begin{array}{l}7.5 Y R \\
4 / 4\end{array}$ & Brown & $\begin{array}{l}\text { Sandy } \\
\text { Clay }\end{array}$ & $\begin{array}{l}>20 \% \text { Calcium } \\
\text { Carbonate, Gravels, } \\
\text { Pebbles }\end{array}$ & Negative & $\begin{array}{l}\text { No cultural material } \\
\text { encountered. Terminated } \\
\text { at compact soil. }\end{array}$ \\
\hline SS011 & $0-55$ & $\begin{array}{l}7.5 Y R \\
4 / 4\end{array}$ & Brown & $\begin{array}{l}\text { Sandy } \\
\text { Clay }\end{array}$ & $\begin{array}{l}>20 \% \text { Calcium } \\
\text { Carbonate, Gravels, } \\
\text { Pebbles }\end{array}$ & Negative & $\begin{array}{l}\text { No cultural material } \\
\text { encountered. Terminated } \\
\text { at compact soil. }\end{array}$ \\
\hline
\end{tabular}




\begin{tabular}{|c|c|c|c|c|c|c|c|}
\hline $\begin{array}{l}\text { STP } \\
\text { No. }\end{array}$ & $\begin{array}{l}\text { Depth } \\
\text { (cmbs) }\end{array}$ & Munsell & Soil Color & $\begin{array}{l}\text { Soil } \\
\text { Texture }\end{array}$ & Inclusions & $\begin{array}{l}\text { Positive/ } \\
\text { Negative }\end{array}$ & $\begin{array}{l}\text { Comments/ } \\
\text { Reason for Termination }\end{array}$ \\
\hline SS012 & $0-10$ & $\begin{array}{l}7.5 Y R \\
4 / 4\end{array}$ & Brown & $\begin{array}{l}\text { Sandy } \\
\text { Clay }\end{array}$ & $\begin{array}{l}>20 \% \text { Cobbles, } \\
\text { Gravels, Large Rock } \\
\text { Frags, Pebbles }\end{array}$ & Negative & $\begin{array}{l}\text { No cultural material } \\
\text { encountered. Terminated } \\
\text { at compact, disturbed. }\end{array}$ \\
\hline SS013 & $0-30$ & $\begin{array}{l}7.5 \mathrm{YR} \\
4 / 4\end{array}$ & Brown & $\begin{array}{l}\text { Sandy } \\
\text { Clay }\end{array}$ & $\begin{array}{l}>20 \% \text { Calcium } \\
\text { Carbonate, Gravels, } \\
\text { Pebbles }\end{array}$ & Negative & $\begin{array}{l}\text { No cultural material } \\
\text { encountered. Terminated } \\
\text { at compact soil. }\end{array}$ \\
\hline SS014 & $0-10$ & $\begin{array}{l}7.5 \mathrm{YR} \\
4 / 4\end{array}$ & Brown & $\begin{array}{l}\text { Sandy } \\
\text { Clay }\end{array}$ & $\begin{array}{l}>20 \% \text { Cobbles, } \\
\text { Gravels, Large Rock } \\
\text { Frags, Pebbles }\end{array}$ & Negative & $\begin{array}{l}\text { No cultural material } \\
\text { encountered. Terminated } \\
\text { at compact, disturbed. }\end{array}$ \\
\hline SS015 & $0-30$ & $\begin{array}{l}7.5 Y R \\
4 / 4\end{array}$ & Brown & $\begin{array}{l}\text { Sandy } \\
\text { Clay }\end{array}$ & $\begin{array}{l}>20 \% \text { Calcium } \\
\text { Carbonate, Gravels, } \\
\text { Pebbles }\end{array}$ & Negative & $\begin{array}{l}\text { No cultural material } \\
\text { encountered. Terminated } \\
\text { at compact soil. }\end{array}$ \\
\hline SS016 & $0-50$ & $\begin{array}{l}7.5 Y R \\
4 / 4\end{array}$ & Brown & $\begin{array}{l}\text { Sandy } \\
\text { Loam }\end{array}$ & $\begin{array}{l}>20 \% \text { Calcium } \\
\text { Carbonate, Cobbles, } \\
\text { Gravels, Pebbles }\end{array}$ & Negative & $\begin{array}{l}\text { No cultural material } \\
\text { encountered. Terminated } \\
\text { at compact soil. }\end{array}$ \\
\hline SS017 & $0-40$ & $\begin{array}{l}7.5 \mathrm{YR} \\
4 / 4\end{array}$ & Brown & $\begin{array}{l}\text { Sandy } \\
\text { Loam }\end{array}$ & $\begin{array}{l}>20 \% \text { Calcium } \\
\text { Carbonate, Cobbles, } \\
\text { Gravels, Pebbles }\end{array}$ & Negative & $\begin{array}{l}\text { No cultural material } \\
\text { encountered. Terminated } \\
\text { at compact soil. }\end{array}$ \\
\hline SS018 & $0-10$ & $\begin{array}{l}7.5 \mathrm{YR} \\
4 / 4\end{array}$ & Brown & $\begin{array}{l}\text { Sandy } \\
\text { Loam }\end{array}$ & $\begin{array}{l}>20 \% \text { Calcium } \\
\text { Carbonate, Cobbles, } \\
\text { Gravels, Pebbles }\end{array}$ & Negative & $\begin{array}{l}\text { No cultural material } \\
\text { encountered. Terminated } \\
\text { at compact soil. }\end{array}$ \\
\hline SS019 & $0-10$ & $\begin{array}{l}7.5 Y R \\
4 / 4\end{array}$ & Brown & $\begin{array}{l}\text { Sandy } \\
\text { Loam }\end{array}$ & $\begin{array}{l}>20 \% \text { Calcium } \\
\text { Carbonate, Cobbles, } \\
\text { Gravels, Pebbles }\end{array}$ & Negative & $\begin{array}{l}\text { No cultural material } \\
\text { encountered. Terminated } \\
\text { at compact soil. }\end{array}$ \\
\hline SS020 & $0-30$ & $\begin{array}{l}7.5 \mathrm{YR} \\
4 / 4\end{array}$ & Brown & $\begin{array}{l}\text { Sandy } \\
\text { Loam }\end{array}$ & $\begin{array}{l}>20 \% \text { Calcium } \\
\text { Carbonate, Cobbles, } \\
\text { Gravels, Pebbles }\end{array}$ & Negative & $\begin{array}{l}\text { No cultural material } \\
\text { encountered. Terminated } \\
\text { at compact soil. }\end{array}$ \\
\hline SS021 & $0-30$ & $\begin{array}{l}7.5 \mathrm{YR} \\
4 / 4\end{array}$ & Brown & $\begin{array}{l}\text { Sandy } \\
\text { Loam }\end{array}$ & $\begin{array}{l}>20 \% \text { Calcium } \\
\text { Carbonate, Cobbles, } \\
\text { Gravels, Pebbles }\end{array}$ & Negative & $\begin{array}{l}\text { No cultural material } \\
\text { encountered. Terminated } \\
\text { at compact soil. }\end{array}$ \\
\hline SS022 & $0-60$ & $\begin{array}{l}7.5 \mathrm{YR} \\
4 / 4\end{array}$ & Brown & $\begin{array}{l}\text { Sandy } \\
\text { Loam }\end{array}$ & $\begin{array}{l}>20 \% \text { Calcium } \\
\text { Carbonate, Cobbles, } \\
\text { Gravels, Pebbles }\end{array}$ & Negative & $\begin{array}{l}\text { No cultural material } \\
\text { encountered. Terminated } \\
\text { at compact soil. }\end{array}$ \\
\hline SS023 & $0-35$ & $\begin{array}{l}7.5 \mathrm{YR} \\
4 / 4\end{array}$ & Brown & $\begin{array}{l}\text { Sandy } \\
\text { Loam }\end{array}$ & $\begin{array}{l}>20 \% \text { Calcium } \\
\text { Carbonate, Cobbles, } \\
\text { Gravels, Pebbles }\end{array}$ & Negative & $\begin{array}{l}\text { No cultural material } \\
\text { encountered. Terminated } \\
\text { at compact soil. }\end{array}$ \\
\hline SS024 & $0-35$ & $\begin{array}{l}7.5 \mathrm{YR} \\
4 / 4\end{array}$ & Brown & $\begin{array}{l}\text { Sandy } \\
\text { Loam }\end{array}$ & $\begin{array}{l}>20 \% \text { Calcium } \\
\text { Carbonate, Cobbles, } \\
\text { Gravels, Pebbles }\end{array}$ & Negative & $\begin{array}{l}\text { No cultural material } \\
\text { encountered. Terminated } \\
\text { at compact soil. }\end{array}$ \\
\hline SS025 & $0-30$ & $\begin{array}{l}7.5 \mathrm{YR} \\
4 / 4\end{array}$ & Brown & $\begin{array}{l}\text { Sandy } \\
\text { Loam }\end{array}$ & $\begin{array}{l}>20 \% \text { Calcium } \\
\text { Carbonate, Cobbles, } \\
\text { Gravels, Pebbles }\end{array}$ & Negative & $\begin{array}{l}\text { No cultural material } \\
\text { encountered. Terminated } \\
\text { at compact soil. }\end{array}$ \\
\hline SS026 & $0-35$ & $\begin{array}{l}7.5 \mathrm{YR} \\
4 / 4\end{array}$ & Brown & $\begin{array}{l}\text { Sandy } \\
\text { Loam }\end{array}$ & $\begin{array}{l}>20 \% \text { Calcium } \\
\text { Carbonate, Cobbles, } \\
\text { Gravels, Pebbles }\end{array}$ & Negative & $\begin{array}{l}\text { No cultural material } \\
\text { encountered. Terminated } \\
\text { at compact soil. }\end{array}$ \\
\hline SS027 & $0-20$ & $\begin{array}{l}7.5 \mathrm{YR} \\
4 / 4\end{array}$ & Brown & $\begin{array}{l}\text { Sandy } \\
\text { Loam }\end{array}$ & $\begin{array}{l}>20 \% \text { Calcium } \\
\text { Carbonate, Cobbles, } \\
\text { Gravels, Pebbles }\end{array}$ & Negative & $\begin{array}{l}\text { No cultural material } \\
\text { encountered. Terminated } \\
\text { at compact soil. }\end{array}$ \\
\hline SS028 & $0-35$ & $\begin{array}{l}7.5 \mathrm{YR} \\
4 / 4\end{array}$ & Brown & $\begin{array}{l}\text { Sandy } \\
\text { Loam }\end{array}$ & $\begin{array}{l}>20 \% \text { Calcium } \\
\text { Carbonate, Cobbles, } \\
\text { Gravels, Pebbles }\end{array}$ & Negative & $\begin{array}{l}\text { No cultural material } \\
\text { encountered. Terminated } \\
\text { at compact soil. }\end{array}$ \\
\hline
\end{tabular}




\begin{tabular}{|c|c|c|c|c|c|c|c|}
\hline $\begin{array}{l}\text { STP } \\
\text { No. }\end{array}$ & $\begin{array}{l}\text { Depth } \\
\text { (cmbs) }\end{array}$ & Munsell & Soil Color & $\begin{array}{l}\text { Soil } \\
\text { Texture }\end{array}$ & Inclusions & $\begin{array}{l}\text { Positive/ } \\
\text { Negative }\end{array}$ & $\begin{array}{l}\text { Comments/ } \\
\text { Reason for Termination }\end{array}$ \\
\hline SS029 & $0-30$ & $\begin{array}{l}7.5 \mathrm{YR} \\
4 / 4\end{array}$ & Brown & $\begin{array}{l}\text { Sandy } \\
\text { Loam }\end{array}$ & $\begin{array}{l}>20 \% \text { Calcium } \\
\text { Carbonate, Cobbles, } \\
\text { Gravels, Pebbles }\end{array}$ & Negative & $\begin{array}{l}\text { No cultural material } \\
\text { encountered. Terminated } \\
\text { at compact soil. }\end{array}$ \\
\hline SS030 & $0-40$ & $\begin{array}{l}7.5 Y R \\
4 / 3\end{array}$ & Brown & $\begin{array}{l}\text { Sandy } \\
\text { Loam }\end{array}$ & $\begin{array}{l}10-20 \% \text { Calcium } \\
\text { Carbonate, Gravels, } \\
\text { Pebbles }\end{array}$ & Negative & $\begin{array}{l}\text { No cultural material } \\
\text { encountered. Terminated } \\
\text { at compact soil. }\end{array}$ \\
\hline SS031 & $0-15$ & $\begin{array}{l}7.5 Y R \\
4 / 3\end{array}$ & Brown & $\begin{array}{l}\text { Sandy } \\
\text { Loam }\end{array}$ & $\begin{array}{l}10-20 \% \text { Calcium } \\
\text { Carbonate, Gravels, } \\
\text { Pebbles }\end{array}$ & Negative & $\begin{array}{l}\text { No cultural material } \\
\text { encountered. Terminated } \\
\text { at compact soil. }\end{array}$ \\
\hline SS032 & $0-40$ & $\begin{array}{l}7.5 Y R \\
4 / 3\end{array}$ & Brown & $\begin{array}{l}\text { Sandy } \\
\text { Loam }\end{array}$ & $\begin{array}{l}10-20 \% \text { Calcium } \\
\text { Carbonate, Gravels, } \\
\text { Pebbles }\end{array}$ & Negative & $\begin{array}{l}\text { No cultural material } \\
\text { encountered. Terminated } \\
\text { at compact soil. }\end{array}$ \\
\hline SS033 & $0-40$ & $\begin{array}{l}7.5 \mathrm{YR} \\
4 / 3\end{array}$ & Brown & $\begin{array}{l}\text { Sandy } \\
\text { Loam }\end{array}$ & $\begin{array}{l}10-20 \% \text { Calcium } \\
\text { Carbonate, Gravels, } \\
\text { Pebbles }\end{array}$ & Negative & $\begin{array}{l}\text { No cultural material } \\
\text { encountered. Terminated } \\
\text { at compact soil. }\end{array}$ \\
\hline SS034 & $0-50$ & $\begin{array}{l}7.5 \mathrm{YR} \\
4 / 3\end{array}$ & Brown & $\begin{array}{l}\text { Sandy } \\
\text { Loam }\end{array}$ & $\begin{array}{l}10-20 \% \text { Calcium } \\
\text { Carbonate, Gravels, } \\
\text { Pebbles }\end{array}$ & Negative & $\begin{array}{l}\text { No cultural material } \\
\text { encountered. Terminated } \\
\text { at compact soil. }\end{array}$ \\
\hline SS035 & $0-40$ & $\begin{array}{l}7.5 \mathrm{YR} \\
4 / 3\end{array}$ & Brown & $\begin{array}{l}\text { Sandy } \\
\text { Loam }\end{array}$ & $\begin{array}{l}10-20 \% \text { Calcium } \\
\text { Carbonate, Gravels, } \\
\text { Pebbles }\end{array}$ & Negative & $\begin{array}{l}\text { No cultural material } \\
\text { encountered. Terminated } \\
\text { at compact soil. }\end{array}$ \\
\hline SS036 & $0-35$ & $\begin{array}{l}7.5 Y R \\
4 / 3\end{array}$ & Brown & $\begin{array}{l}\text { Sandy } \\
\text { Loam }\end{array}$ & $\begin{array}{l}10-20 \% \text { Calcium } \\
\text { Carbonate, Gravels, } \\
\text { Pebbles }\end{array}$ & Negative & $\begin{array}{l}\text { No cultural material } \\
\text { encountered. Terminated } \\
\text { at compact soil. }\end{array}$ \\
\hline SS037 & $0-40$ & $\begin{array}{l}7.5 \mathrm{YR} \\
4 / 3\end{array}$ & Brown & $\begin{array}{l}\text { Sandy } \\
\text { Loam }\end{array}$ & $\begin{array}{l}10-20 \% \text { Calcium } \\
\text { Carbonate, Gravels, } \\
\text { Pebbles }\end{array}$ & Negative & $\begin{array}{l}\text { No cultural material } \\
\text { encountered. Terminated } \\
\text { at compact soil. }\end{array}$ \\
\hline SS038 & $0-25$ & $\begin{array}{l}7.5 Y R \\
4 / 3\end{array}$ & Brown & $\begin{array}{l}\text { Sandy } \\
\text { Loam }\end{array}$ & $\begin{array}{l}10-20 \% \text { Calcium } \\
\text { Carbonate, Gravels, } \\
\text { Pebbles }\end{array}$ & Negative & $\begin{array}{l}\text { No cultural material } \\
\text { encountered. Terminated } \\
\text { at compact soil. }\end{array}$ \\
\hline SS039 & $0-55$ & $\begin{array}{l}7.5 Y R \\
4 / 3\end{array}$ & Brown & $\begin{array}{l}\text { Sandy } \\
\text { Loam }\end{array}$ & $\begin{array}{l}10-20 \% \text { Calcium } \\
\text { Carbonate, Gravels, } \\
\text { Pebbles }\end{array}$ & Negative & $\begin{array}{l}\text { No cultural material } \\
\text { encountered. Terminated } \\
\text { at compact soil. }\end{array}$ \\
\hline SS040 & $0-50$ & $\begin{array}{l}7.5 Y R \\
4 / 3\end{array}$ & Brown & $\begin{array}{l}\text { Sandy } \\
\text { Loam }\end{array}$ & $\begin{array}{l}10-20 \% \text { Calcium } \\
\text { Carbonate, Gravels, } \\
\text { Pebbles }\end{array}$ & Negative & $\begin{array}{l}\text { No cultural material } \\
\text { encountered. Terminated } \\
\text { at compact soil. }\end{array}$ \\
\hline SS041 & $0-40$ & $\begin{array}{l}7.5 \mathrm{YR} \\
4 / 3\end{array}$ & Brown & $\begin{array}{l}\text { Sandy } \\
\text { Loam }\end{array}$ & $\begin{array}{l}10-20 \% \text { Calcium } \\
\text { Carbonate, Gravels, } \\
\text { Pebbles }\end{array}$ & Negative & $\begin{array}{l}\text { No cultural material } \\
\text { encountered. Terminated } \\
\text { at compact soil. }\end{array}$ \\
\hline SS042 & $0-40$ & $\begin{array}{l}7.5 \mathrm{YR} \\
4 / 3\end{array}$ & Brown & $\begin{array}{l}\text { Sandy } \\
\text { Loam }\end{array}$ & $\begin{array}{l}10-20 \% \text { Calcium } \\
\text { Carbonate, Gravels, } \\
\text { Pebbles }\end{array}$ & Negative & $\begin{array}{l}\text { No cultural material } \\
\text { encountered. Terminated } \\
\text { at compact soil. }\end{array}$ \\
\hline SS043 & $0-25$ & $\begin{array}{l}7.5 Y R \\
4 / 3\end{array}$ & Brown & $\begin{array}{l}\text { Sandy } \\
\text { Loam }\end{array}$ & $\begin{array}{l}10-20 \% \text { Calcium } \\
\text { Carbonate, Gravels, } \\
\text { Pebbles }\end{array}$ & Negative & $\begin{array}{l}\text { No cultural material } \\
\text { encountered. Terminated } \\
\text { at compact soil. }\end{array}$ \\
\hline SS044 & $0-30$ & $\begin{array}{l}7.5 \mathrm{YR} \\
4 / 4\end{array}$ & Brown & $\begin{array}{l}\text { Sandy } \\
\text { Loam }\end{array}$ & $>20 \%$ Gravels & Negative & $\begin{array}{l}\text { No cultural material } \\
\text { encountered. Terminated } \\
\text { at compact soil. }\end{array}$ \\
\hline SS045 & $0-30$ & $\begin{array}{l}10 Y R \\
5 / 4\end{array}$ & $\begin{array}{l}\text { Yellowish } \\
\text { Brown }\end{array}$ & $\begin{array}{l}\text { Sandy } \\
\text { Loam }\end{array}$ & $\begin{array}{l}10-20 \% \text { Calcium } \\
\text { Carbonate, Cobbles, } \\
\text { Gravels, Pebbles }\end{array}$ & Negative & $\begin{array}{l}\text { No cultural material } \\
\text { encountered. Terminated } \\
\text { at compact soil. }\end{array}$ \\
\hline
\end{tabular}




\begin{tabular}{|c|c|c|c|c|c|c|c|}
\hline $\begin{array}{l}\text { STP } \\
\text { No. }\end{array}$ & $\begin{array}{l}\text { Depth } \\
\text { (cmbs) }\end{array}$ & Munsell & Soil Color & $\begin{array}{l}\text { Soil } \\
\text { Texture }\end{array}$ & Inclusions & $\begin{array}{l}\text { Positive/ } \\
\text { Negative }\end{array}$ & $\begin{array}{l}\text { Comments/ } \\
\text { Reason for Termination }\end{array}$ \\
\hline SS046 & $0-15$ & $\begin{array}{l}7.5 Y R \\
4 / 4\end{array}$ & Brown & $\begin{array}{l}\text { Sandy } \\
\text { Loam }\end{array}$ & $\begin{array}{l}>20 \% \text { Calcium } \\
\text { Carbonate, Cobbles, } \\
\text { Gravels, Pebbles }\end{array}$ & Negative & $\begin{array}{l}\text { No cultural material } \\
\text { encountered. Terminated } \\
\text { at compact soil. }\end{array}$ \\
\hline SS047 & $0-30$ & $\begin{array}{l}10 Y R \\
5 / 4\end{array}$ & $\begin{array}{l}\text { Yellowish } \\
\text { Brown }\end{array}$ & $\begin{array}{l}\text { Sandy } \\
\text { Loam }\end{array}$ & $\begin{array}{l}10-20 \% \text { Calcium } \\
\text { Carbonate, Cobbles, } \\
\text { Gravels, Pebbles }\end{array}$ & Negative & $\begin{array}{l}\text { No cultural material } \\
\text { encountered. Terminated } \\
\text { at compact soil. }\end{array}$ \\
\hline SS048 & $0-65$ & $\begin{array}{l}7.5 Y R \\
4 / 4\end{array}$ & Brown & $\begin{array}{l}\text { Sandy } \\
\text { Loam }\end{array}$ & $\begin{array}{l}>20 \% \text { Calcium } \\
\text { Carbonate, Cobbles, } \\
\text { Gravels, Pebbles }\end{array}$ & Negative & $\begin{array}{l}\text { No cultural material } \\
\text { encountered. Terminated } \\
\text { at compact soil. }\end{array}$ \\
\hline SS049 & $0-40$ & $\begin{array}{l}10 Y R \\
5 / 4\end{array}$ & $\begin{array}{l}\text { Yellowish } \\
\text { Brown }\end{array}$ & $\begin{array}{l}\text { Sandy } \\
\text { Loam }\end{array}$ & $\begin{array}{l}10-20 \% \text { Calcium } \\
\text { Carbonate, Cobbles, } \\
\text { Gravels, Pebbles }\end{array}$ & Negative & $\begin{array}{l}\text { No cultural material } \\
\text { encountered. Terminated } \\
\text { at compact soil. }\end{array}$ \\
\hline SS050 & $0-40$ & $\begin{array}{l}10 Y R \\
5 / 4\end{array}$ & $\begin{array}{l}\text { Yellowish } \\
\text { Brown }\end{array}$ & $\begin{array}{l}\text { Sandy } \\
\text { Loam }\end{array}$ & $\begin{array}{l}10-20 \% \text { Calcium } \\
\text { Carbonate, Cobbles, } \\
\text { Gravels, Pebbles }\end{array}$ & Negative & $\begin{array}{l}\text { No cultural material } \\
\text { encountered. Terminated } \\
\text { at compact soil. }\end{array}$ \\
\hline SS051 & $0-35$ & $\begin{array}{l}7.5 \mathrm{YR} \\
4 / 4\end{array}$ & Brown & $\begin{array}{l}\text { Sandy } \\
\text { Loam }\end{array}$ & $\begin{array}{l}>20 \% \text { Calcium } \\
\text { Carbonate, Cobbles, } \\
\text { Gravels, Pebbles }\end{array}$ & Negative & $\begin{array}{l}\text { No cultural material } \\
\text { encountered. Terminated } \\
\text { at compact soil. }\end{array}$ \\
\hline SS052 & $0-65$ & $\begin{array}{l}7.5 Y R \\
5 / 3\end{array}$ & Brown & $\begin{array}{l}\text { Sandy } \\
\text { Loam }\end{array}$ & $\begin{array}{l}\text { 1-5\% Calcium } \\
\text { Carbonate }\end{array}$ & Negative & $\begin{array}{l}\text { No cultural material } \\
\text { encountered. Terminated } \\
\text { at compact soil. }\end{array}$ \\
\hline SS053 & $0-60$ & $\begin{array}{l}7.5 \mathrm{YR} \\
5 / 3\end{array}$ & Brown & $\begin{array}{l}\text { Sandy } \\
\text { Loam }\end{array}$ & $\begin{array}{l}1-5 \% \text { Calcium } \\
\text { Carbonate }\end{array}$ & Negative & $\begin{array}{l}\text { No cultural material } \\
\text { encountered. Terminated } \\
\text { at compact soil. }\end{array}$ \\
\hline SS054 & $0-50$ & $\begin{array}{l}7.5 \mathrm{YR} \\
5 / 3\end{array}$ & Brown & $\begin{array}{l}\text { Sandy } \\
\text { Loam }\end{array}$ & $\begin{array}{l}1-5 \% \text { Calcium } \\
\text { Carbonate }\end{array}$ & Negative & $\begin{array}{l}\text { No cultural material } \\
\text { encountered. Terminated } \\
\text { at compact soil. }\end{array}$ \\
\hline SS055 & $0-30$ & $\begin{array}{l}7.5 \mathrm{YR} \\
5 / 3\end{array}$ & Brown & $\begin{array}{l}\text { Sandy } \\
\text { Loam }\end{array}$ & $\begin{array}{l}1-5 \% \text { Calcium } \\
\text { Carbonate }\end{array}$ & Negative & $\begin{array}{l}\text { No cultural material } \\
\text { encountered. Terminated } \\
\text { at compact soil. }\end{array}$ \\
\hline SS056 & $0-65$ & $\begin{array}{l}7.5 \mathrm{YR} \\
5 / 3\end{array}$ & Brown & $\begin{array}{l}\text { Sandy } \\
\text { Loam }\end{array}$ & $\begin{array}{l}1-5 \% \text { Calcium } \\
\text { Carbonate }\end{array}$ & Negative & $\begin{array}{l}\text { No cultural material } \\
\text { encountered. Terminated } \\
\text { at compact soil. }\end{array}$ \\
\hline SS057 & $0-60$ & $\begin{array}{l}7.5 \mathrm{YR} \\
5 / 4\end{array}$ & Brown & $\begin{array}{l}\text { Sandy } \\
\text { Loam }\end{array}$ & $\begin{array}{l}1-5 \% \text { Calcium } \\
\text { Carbonate }\end{array}$ & Negative & $\begin{array}{l}\text { No cultural material } \\
\text { encountered. Terminated } \\
\text { at compact soil. }\end{array}$ \\
\hline SS058 & $0-50$ & $\begin{array}{l}7.5 \mathrm{YR} \\
5 / 3\end{array}$ & Brown & $\begin{array}{l}\text { Sandy } \\
\text { Loam }\end{array}$ & $\begin{array}{l}\text { 1-5\% Calcium } \\
\text { Carbonate }\end{array}$ & Negative & $\begin{array}{l}\text { No cultural material } \\
\text { encountered. Terminated } \\
\text { at compact soil. }\end{array}$ \\
\hline SS059 & $0-45$ & $\begin{array}{l}7.5 \mathrm{YR} \\
5 / 3\end{array}$ & Brown & $\begin{array}{l}\text { Sandy } \\
\text { Loam }\end{array}$ & $\begin{array}{l}1-5 \% \text { Calcium } \\
\text { Carbonate }\end{array}$ & Negative & $\begin{array}{l}\text { No cultural material } \\
\text { encountered. Terminated } \\
\text { at compact soil. }\end{array}$ \\
\hline SS060 & $0-40$ & $\begin{array}{l}7.5 \mathrm{YR} \\
5 / 3\end{array}$ & Brown & $\begin{array}{l}\text { Sandy } \\
\text { Loam }\end{array}$ & $\begin{array}{l}1-5 \% \text { Calcium } \\
\text { Carbonate }\end{array}$ & Negative & $\begin{array}{l}\text { No cultural material } \\
\text { encountered. Terminated } \\
\text { at compact soil. }\end{array}$ \\
\hline SS061 & $0-40$ & $\begin{array}{l}7.5 \mathrm{YR} \\
5 / 3\end{array}$ & Brown & $\begin{array}{l}\text { Sandy } \\
\text { Loam }\end{array}$ & $\begin{array}{l}\text { 1-5\% Calcium } \\
\text { Carbonate }\end{array}$ & Negative & $\begin{array}{l}\text { No cultural material } \\
\text { encountered. Terminated } \\
\text { at compact soil. }\end{array}$ \\
\hline SS062 & $0-55$ & $\begin{array}{l}7.5 \mathrm{YR} \\
4 / 4\end{array}$ & Brown & $\begin{array}{l}\text { Sandy } \\
\text { Loam }\end{array}$ & $\begin{array}{l}\text { 1-5\% Calcium } \\
\text { Carbonate }\end{array}$ & Negative & $\begin{array}{l}\text { No cultural material } \\
\text { encountered. Terminated } \\
\text { at compact soil. }\end{array}$ \\
\hline
\end{tabular}




\begin{tabular}{|c|c|c|c|c|c|c|c|}
\hline $\begin{array}{l}\text { STP } \\
\text { No. }\end{array}$ & $\begin{array}{l}\text { Depth } \\
\text { (cmbs) }\end{array}$ & Munsell & Soil Color & $\begin{array}{l}\text { Soil } \\
\text { Texture }\end{array}$ & Inclusions & $\begin{array}{l}\text { Positive/ } \\
\text { Negative }\end{array}$ & $\begin{array}{l}\text { Comments/ } \\
\text { Reason for Termination }\end{array}$ \\
\hline SS063 & $0-40$ & $\begin{array}{l}7.5 \mathrm{YR} \\
4 / 4\end{array}$ & Brown & $\begin{array}{l}\text { Sandy } \\
\text { Loam }\end{array}$ & $\begin{array}{l}1-5 \% \text { Calcium } \\
\text { Carbonate }\end{array}$ & Negative & $\begin{array}{l}\text { No cultural material } \\
\text { encountered. Terminated } \\
\text { at compact soil. }\end{array}$ \\
\hline SS064 & $0-35$ & $\begin{array}{l}7.5 Y R \\
4 / 4\end{array}$ & Brown & $\begin{array}{l}\text { Sandy } \\
\text { Loam }\end{array}$ & $\begin{array}{l}\text { 1-5\% Calcium } \\
\text { Carbonate }\end{array}$ & Negative & $\begin{array}{l}\text { No cultural material } \\
\text { encountered. Terminated } \\
\text { at compact soil. }\end{array}$ \\
\hline SS065 & $0-40$ & $\begin{array}{l}7.5 Y R \\
5 / 3\end{array}$ & Brown & $\begin{array}{l}\text { Sandy } \\
\text { Loam }\end{array}$ & $\begin{array}{l}1-5 \% \text { Calcium } \\
\text { Carbonate }\end{array}$ & Negative & $\begin{array}{l}\text { No cultural material } \\
\text { encountered. Terminated } \\
\text { at compact soil. }\end{array}$ \\
\hline SS066 & $0-55$ & $\begin{array}{l}7.5 \mathrm{YR} \\
4 / 4\end{array}$ & Brown & $\begin{array}{l}\text { Sandy } \\
\text { Loam }\end{array}$ & $\begin{array}{l}1-5 \% \text { Calcium } \\
\text { Carbonate }\end{array}$ & Negative & $\begin{array}{l}\text { No cultural material } \\
\text { encountered. Terminated } \\
\text { at compact soil. }\end{array}$ \\
\hline SS067 & $0-40$ & $\begin{array}{l}7.5 Y R \\
5 / 3\end{array}$ & Brown & $\begin{array}{l}\text { Sandy } \\
\text { Loam }\end{array}$ & $\begin{array}{l}1-5 \% \text { Calcium } \\
\text { Carbonate }\end{array}$ & Negative & $\begin{array}{l}\text { No cultural material } \\
\text { encountered. Terminated } \\
\text { at compact soil. }\end{array}$ \\
\hline SS068 & $0-40$ & $\begin{array}{l}7.5 Y R \\
5 / 3\end{array}$ & Brown & $\begin{array}{l}\text { Sandy } \\
\text { Loam }\end{array}$ & $\begin{array}{l}\text { 1-5\% Calcium } \\
\text { Carbonate }\end{array}$ & Negative & $\begin{array}{l}\text { No cultural material } \\
\text { encountered. Terminated } \\
\text { at compact soil. }\end{array}$ \\
\hline SS069 & $0-60$ & $\begin{array}{l}7.5 \mathrm{YR} \\
4 / 4\end{array}$ & Brown & $\begin{array}{l}\text { Sandy } \\
\text { Loam }\end{array}$ & $\begin{array}{l}\text { 1-5\% Calcium } \\
\text { Carbonate }\end{array}$ & Negative & $\begin{array}{l}\text { No cultural material } \\
\text { encountered. Terminated } \\
\text { at compact soil. }\end{array}$ \\
\hline SS070 & $0-35$ & $\begin{array}{l}7.5 \mathrm{YR} \\
4 / 4\end{array}$ & Brown & $\begin{array}{l}\text { Sandy } \\
\text { Loam }\end{array}$ & $\begin{array}{l}1-5 \% \text { Calcium } \\
\text { Carbonate }\end{array}$ & Negative & $\begin{array}{l}\text { No cultural material } \\
\text { encountered. Terminated } \\
\text { at compact soil. }\end{array}$ \\
\hline SS071 & $0-55$ & $\begin{array}{l}7.5 \mathrm{YR} \\
5 / 4\end{array}$ & Brown & $\begin{array}{l}\text { Sandy } \\
\text { Loam }\end{array}$ & $\begin{array}{l}10-20 \% \text { Calcium } \\
\text { Carbonate, Cobbles, } \\
\text { Gravels, Pebbles }\end{array}$ & Negative & $\begin{array}{l}\text { No cultural material } \\
\text { encountered. Terminated } \\
\text { at bedrock. }\end{array}$ \\
\hline SS072 & $0-50$ & $\begin{array}{l}7.5 \mathrm{YR} \\
4 / 4\end{array}$ & Brown & $\begin{array}{l}\text { Sandy } \\
\text { Loam }\end{array}$ & $\begin{array}{l}1-5 \% \text { Calcium } \\
\text { Carbonate }\end{array}$ & Negative & $\begin{array}{l}\text { No cultural material } \\
\text { encountered. Terminated } \\
\text { at compact soil. }\end{array}$ \\
\hline SS073 & $0-30$ & $\begin{array}{l}7.5 \mathrm{YR} \\
4 / 4\end{array}$ & Brown & $\begin{array}{l}\text { Sandy } \\
\text { Loam }\end{array}$ & $\begin{array}{l}1-5 \% \text { Calcium } \\
\text { Carbonate }\end{array}$ & Negative & $\begin{array}{l}\text { No cultural material } \\
\text { encountered. Terminated } \\
\text { at compact soil. }\end{array}$ \\
\hline SS074 & $0-45$ & $\begin{array}{l}7.5 Y R \\
4 / 4\end{array}$ & Brown & $\begin{array}{l}\text { Sandy } \\
\text { Loam }\end{array}$ & $\begin{array}{l}\text { 1-5\% Calcium } \\
\text { Carbonate }\end{array}$ & Negative & $\begin{array}{l}\text { No cultural material } \\
\text { encountered. Terminated } \\
\text { at compact soil. }\end{array}$ \\
\hline SS075 & $0-50$ & $\begin{array}{l}7.5 \mathrm{YR} \\
4 / 4\end{array}$ & Brown & $\begin{array}{l}\text { Sandy } \\
\text { Loam }\end{array}$ & $\begin{array}{l}1-5 \% \text { Calcium } \\
\text { Carbonate }\end{array}$ & Negative & $\begin{array}{l}\text { No cultural material } \\
\text { encountered. Terminated } \\
\text { at compact soil. }\end{array}$ \\
\hline SS076 & $0-20$ & $\begin{array}{l}7.5 \mathrm{YR} \\
7 / 4\end{array}$ & Pink & $\begin{array}{l}\text { Sandy } \\
\text { Loam }\end{array}$ & $\begin{array}{l}>20 \% \text { Calcium } \\
\text { Carbonate, Cobbles, } \\
\text { Gravels, Large Rock } \\
\text { Frags, Pebbles }\end{array}$ & Negative & $\begin{array}{l}\text { No cultural material } \\
\text { encountered. Terminated } \\
\text { at bedrock. }\end{array}$ \\
\hline SS077 & $0-40$ & $\begin{array}{l}7.5 Y R \\
5 / 3\end{array}$ & Brown & $\begin{array}{l}\text { Sandy } \\
\text { Loam }\end{array}$ & $\begin{array}{l}\text { 1-5\% Calcium } \\
\text { Carbonate }\end{array}$ & Negative & $\begin{array}{l}\text { No cultural material } \\
\text { encountered. Terminated } \\
\text { at compact soil. }\end{array}$ \\
\hline SS078 & $0-60$ & 5YR 4/6 & $\begin{array}{l}\text { Yellowish } \\
\text { Red }\end{array}$ & $\begin{array}{l}\text { Sandy } \\
\text { Loam }\end{array}$ & $\begin{array}{l}1-5 \% \text { Calcium } \\
\text { Carbonate, Gravels, } \\
\text { Pebbles }\end{array}$ & Negative & $\begin{array}{l}\text { No cultural material } \\
\text { encountered. Terminated } \\
\text { at compact soil. }\end{array}$ \\
\hline SS079 & $0-30$ & 5YR 4/6 & $\begin{array}{l}\text { Yellowish } \\
\text { Red }\end{array}$ & $\begin{array}{l}\text { Sandy } \\
\text { Loam }\end{array}$ & $\begin{array}{l}>20 \% \text { Calcium } \\
\text { Carbonate, Cobbles, } \\
\text { Gravels, Pebbles }\end{array}$ & Negative & $\begin{array}{l}\text { No cultural material } \\
\text { encountered. Terminated } \\
\text { at bedrock. }\end{array}$ \\
\hline
\end{tabular}




\begin{tabular}{|c|c|c|c|c|c|c|c|}
\hline $\begin{array}{l}\text { STP } \\
\text { No. }\end{array}$ & $\begin{array}{l}\text { Depth } \\
\text { (cmbs) }\end{array}$ & Munsell & Soil Color & $\begin{array}{l}\text { Soil } \\
\text { Texture }\end{array}$ & Inclusions & $\begin{array}{l}\text { Positive/ } \\
\text { Negative }\end{array}$ & $\begin{array}{l}\text { Comments/ } \\
\text { Reason for Termination }\end{array}$ \\
\hline SS080 & $0-60$ & $\begin{array}{l}7.5 \mathrm{YR} \\
4 / 4\end{array}$ & Brown & $\begin{array}{l}\text { Sandy } \\
\text { Loam }\end{array}$ & $\begin{array}{l}1-5 \% \text { Calcium } \\
\text { Carbonate }\end{array}$ & Negative & $\begin{array}{l}\text { No cultural material } \\
\text { encountered. Terminated } \\
\text { at compact soil. }\end{array}$ \\
\hline SS081 & $0-15$ & $\begin{array}{l}7.5 \mathrm{YR} \\
4 / 4\end{array}$ & Brown & $\begin{array}{l}\text { Sandy } \\
\text { Loam }\end{array}$ & $\begin{array}{l}>20 \% \text { Calcium } \\
\text { Carbonate, Cobbles, } \\
\text { Gravels, Large Rock } \\
\text { Frags, Pebbles }\end{array}$ & Negative & $\begin{array}{l}\text { No cultural material } \\
\text { encountered. Terminated } \\
\text { at bedrock. }\end{array}$ \\
\hline \multirow[b]{2}{*}{ SS082 } & $0-70$ & $\begin{array}{l}10 Y R \\
5 / 4\end{array}$ & $\begin{array}{l}\text { Yellowish } \\
\text { Brown }\end{array}$ & $\begin{array}{l}\text { Sandy } \\
\text { Loam }\end{array}$ & $\begin{array}{l}1-5 \% \text { Calcium } \\
\text { Carbonate }\end{array}$ & Negative & $\begin{array}{l}\text { No cultural material } \\
\text { encountered. }\end{array}$ \\
\hline & $70-80$ & $\begin{array}{l}10 Y R \\
6 / 4\end{array}$ & $\begin{array}{l}\text { Light } \\
\text { Yellowish } \\
\text { Brown }\end{array}$ & $\begin{array}{l}\text { Sandy } \\
\text { Loam }\end{array}$ & $\begin{array}{l}1-5 \% \text { Calcium } \\
\text { Carbonate }\end{array}$ & Negative & $\begin{array}{l}\text { No cultural material } \\
\text { encountered. Terminated } \\
\text { at basal clay. }\end{array}$ \\
\hline SS083 & $0-35$ & $\begin{array}{l}10 Y R \\
4 / 4\end{array}$ & $\begin{array}{l}\text { Dark } \\
\text { Yellowish } \\
\text { Brown }\end{array}$ & $\begin{array}{l}\text { Sandy } \\
\text { Clay } \\
\text { Loam }\end{array}$ & $\begin{array}{l}1-5 \% \text { Calcium } \\
\text { Carbonate }\end{array}$ & Negative & $\begin{array}{l}\text { No cultural material } \\
\text { encountered. Terminated } \\
\text { at compact soil. }\end{array}$ \\
\hline SS084 & $0-100$ & 5YR 5/6 & $\begin{array}{l}\text { Yellowish } \\
\text { Red }\end{array}$ & $\begin{array}{l}\text { Sandy } \\
\text { Loam }\end{array}$ & $\begin{array}{l}1-5 \% \text { Calcium } \\
\text { Carbonate }\end{array}$ & Negative & $\begin{array}{l}\text { No cultural material } \\
\text { encountered. Terminated } \\
\text { at depth. }\end{array}$ \\
\hline SS085 & $0-100$ & 5YR 5/6 & $\begin{array}{l}\text { Yellowish } \\
\text { Red }\end{array}$ & $\begin{array}{l}\text { Sandy } \\
\text { Loam }\end{array}$ & $\begin{array}{l}1-5 \% \text { Calcium } \\
\text { Carbonate }\end{array}$ & Negative & $\begin{array}{l}\text { No cultural material } \\
\text { encountered. Terminated } \\
\text { at depth. }\end{array}$ \\
\hline SS086 & $0-100$ & 5YR 5/6 & $\begin{array}{l}\text { Yellowish } \\
\text { Red }\end{array}$ & $\begin{array}{l}\text { Sandy } \\
\text { Loam }\end{array}$ & $\begin{array}{l}1-5 \% \text { Calcium } \\
\text { Carbonate }\end{array}$ & Negative & $\begin{array}{l}\text { No cultural material } \\
\text { encountered. Terminated } \\
\text { at depth. }\end{array}$ \\
\hline SS087 & $0-100$ & 5YR 5/6 & $\begin{array}{l}\text { Yellowish } \\
\text { Red }\end{array}$ & $\begin{array}{l}\text { Sandy } \\
\text { Loam }\end{array}$ & $\begin{array}{l}1-5 \% \text { Calcium } \\
\text { Carbonate }\end{array}$ & Negative & $\begin{array}{l}\text { No cultural material } \\
\text { encountered. Terminated } \\
\text { at depth. }\end{array}$ \\
\hline SS088 & $0-66$ & 5YR 5/6 & $\begin{array}{l}\text { Yellowish } \\
\text { Red }\end{array}$ & $\begin{array}{l}\text { Sandy } \\
\text { Loam }\end{array}$ & $\begin{array}{l}1-5 \% \text { Calcium } \\
\text { Carbonate }\end{array}$ & Negative & $\begin{array}{l}\text { No cultural material } \\
\text { encountered. Terminated } \\
\text { at impenetrable root. }\end{array}$ \\
\hline \multirow[b]{2}{*}{ SS089 } & $0-60$ & $\begin{array}{l}7.5 \mathrm{YR} \\
4 / 4\end{array}$ & Brown & $\begin{array}{l}\text { Sandy } \\
\text { Loam }\end{array}$ & $\begin{array}{l}\text { 1-5\% Calcium } \\
\text { Carbonate }\end{array}$ & Negative & $\begin{array}{l}\text { No cultural material } \\
\text { encountered. }\end{array}$ \\
\hline & $60-80$ & 5YR 5/6 & $\begin{array}{l}\text { Yellowish } \\
\text { Red }\end{array}$ & $\begin{array}{l}\text { Sandy } \\
\text { Loam }\end{array}$ & $\begin{array}{l}\text { 1-5\% Calcium } \\
\text { Carbonate }\end{array}$ & Negative & $\begin{array}{l}\text { No cultural material } \\
\text { encountered. Terminated } \\
\text { at compact soil. }\end{array}$ \\
\hline SS090 & $0-70$ & $\begin{array}{l}7.5 \mathrm{YR} \\
4 / 4\end{array}$ & Brown & $\begin{array}{l}\text { Sandy } \\
\text { Loam }\end{array}$ & $\begin{array}{l}1-5 \% \text { Calcium } \\
\text { Carbonate }\end{array}$ & Negative & $\begin{array}{l}\text { No cultural material } \\
\text { encountered. Terminated } \\
\text { at basal clay. }\end{array}$ \\
\hline SS091 & $0-90$ & $\begin{array}{l}7.5 \mathrm{YR} \\
4 / 4\end{array}$ & Brown & $\begin{array}{l}\text { Sandy } \\
\text { Loam }\end{array}$ & $\begin{array}{l}1-5 \% \text { Calcium } \\
\text { Carbonate }\end{array}$ & Negative & $\begin{array}{l}\text { No cultural material } \\
\text { encountered. Terminated } \\
\text { at basal clay. }\end{array}$ \\
\hline SS092 & $0-100$ & 5YR 5/6 & $\begin{array}{l}\text { Yellowish } \\
\text { Red }\end{array}$ & $\begin{array}{l}\text { Sandy } \\
\text { Loam }\end{array}$ & $\begin{array}{l}1-5 \% \text { Calcium } \\
\text { Carbonate }\end{array}$ & Negative & $\begin{array}{l}\text { No cultural material } \\
\text { encountered. Terminated } \\
\text { at depth. }\end{array}$ \\
\hline \multirow[b]{2}{*}{ SS093 } & $0-60$ & $\begin{array}{l}7.5 \mathrm{YR} \\
4 / 4\end{array}$ & Brown & $\begin{array}{l}\text { Sandy } \\
\text { Loam }\end{array}$ & $1 \%$ Cobbles & Negative & $\begin{array}{l}\text { No cultural material } \\
\text { encountered. }\end{array}$ \\
\hline & $60-65$ & 5YR 5/6 & $\begin{array}{l}\text { Yellowish } \\
\text { Red }\end{array}$ & $\begin{array}{l}\text { Sandy } \\
\text { Clay } \\
\text { Loam }\end{array}$ & $\begin{array}{l}1-5 \% \text { Calcium } \\
\text { Carbonate }\end{array}$ & Negative & $\begin{array}{l}\text { No cultural material } \\
\text { encountered. Terminated } \\
\text { at basal clay. }\end{array}$ \\
\hline SS094 & $0-30$ & $\begin{array}{l}7.5 \mathrm{YR} \\
4 / 4\end{array}$ & Brown & $\begin{array}{l}\text { Sandy } \\
\text { Loam }\end{array}$ & $\begin{array}{l}>20 \% \text { Cobbles, } \\
\text { Gravels, Large Rock } \\
\text { Frags, Pebbles }\end{array}$ & Negative & $\begin{array}{l}\text { No cultural material } \\
\text { encountered. Terminated } \\
\text { at bedrock. }\end{array}$ \\
\hline
\end{tabular}




\begin{tabular}{|c|c|c|c|c|c|c|c|}
\hline $\begin{array}{l}\text { STP } \\
\text { No. }\end{array}$ & $\begin{array}{l}\text { Depth } \\
\text { (cmbs) }\end{array}$ & Munsell & Soil Color & $\begin{array}{l}\text { Soil } \\
\text { Texture }\end{array}$ & Inclusions & $\begin{array}{l}\text { Positive/ } \\
\text { Negative }\end{array}$ & $\begin{array}{l}\text { Comments/ } \\
\text { Reason for Termination }\end{array}$ \\
\hline SS095 & $0-15$ & $\begin{array}{l}7.5 \mathrm{YR} \\
4 / 4\end{array}$ & Brown & $\begin{array}{l}\text { Sandy } \\
\text { Loam }\end{array}$ & $\begin{array}{l}1-5 \% \text { Cobbles, } 1 \\
\text { cobble }\end{array}$ & Negative & $\begin{array}{l}\text { No cultural material } \\
\text { encountered. }\end{array}$ \\
\hline \multirow{2}{*}{ SS096 } & $0-60$ & $\begin{array}{l}7.5 \mathrm{YR} \\
4 / 4\end{array}$ & Brown & $\begin{array}{l}\text { Sandy } \\
\text { Loam }\end{array}$ & $\begin{array}{l}1-5 \% \text { Cobbles, } 1 \\
\text { cobble }\end{array}$ & Negative & $\begin{array}{l}\text { No cultural material } \\
\text { encountered. Terminated } \\
\text { at basal clay. }\end{array}$ \\
\hline & $60-65$ & 5YR 5/6 & $\begin{array}{l}\text { Yellowish } \\
\text { Red }\end{array}$ & $\begin{array}{l}\text { Sandy } \\
\text { Clay } \\
\text { Loam }\end{array}$ & 1-5\% Cobbles & Negative & $\begin{array}{l}\text { No cultural material } \\
\text { encountered. Terminated } \\
\text { at basal clay. }\end{array}$ \\
\hline \multirow[b]{2}{*}{ SS097 } & $0-30$ & $\begin{array}{l}7.5 Y R \\
7 / 4\end{array}$ & Pink & Sand & 1-5\% Cobbles & Negative & $\begin{array}{l}\text { No cultural material } \\
\text { encountered. }\end{array}$ \\
\hline & $30-50$ & 5YR 5/6 & $\begin{array}{l}\text { Yellowish } \\
\text { Red }\end{array}$ & $\begin{array}{l}\text { Sandy } \\
\text { Clay }\end{array}$ & 1-5\% Cobbles & Negative & $\begin{array}{l}\text { No cultural material } \\
\text { encountered. Terminated } \\
\text { at compact soil. }\end{array}$ \\
\hline \multirow{3}{*}{ SS098 } & $0-30$ & $\begin{array}{l}7.5 Y R \\
7 / 4\end{array}$ & Pink & Sand & 1-5\% Cobbles & Negative & $\begin{array}{l}\text { No cultural material } \\
\text { encountered. }\end{array}$ \\
\hline & $30-90$ & 5YR 5/6 & $\begin{array}{l}\text { Yellowish } \\
\text { Red }\end{array}$ & $\begin{array}{l}\text { Sandy } \\
\text { Loam }\end{array}$ & 1-5\% Cobbles & Negative & $\begin{array}{l}\text { No cultural material } \\
\text { encountered. }\end{array}$ \\
\hline & $90-100$ & $\begin{array}{l}7.5 \mathrm{YR} \\
5 / 6\end{array}$ & $\begin{array}{l}\text { Strong } \\
\text { Brown }\end{array}$ & $\begin{array}{l}\text { Sandy } \\
\text { Clay } \\
\text { Loam }\end{array}$ & 1-5\% Cobbles & Negative & $\begin{array}{l}\text { No cultural material } \\
\text { encountered. Terminated } \\
\text { at depth. }\end{array}$ \\
\hline SS099 & $0-70$ & $\begin{array}{l}7.5 Y R \\
4 / 4\end{array}$ & Brown & $\begin{array}{l}\text { Sandy } \\
\text { Loam }\end{array}$ & 1-5\% Cobbles & Negative & $\begin{array}{l}\text { No cultural material } \\
\text { encountered. Terminated } \\
\text { at basal clay. }\end{array}$ \\
\hline SS100 & $0-70$ & $\begin{array}{l}7.5 Y R \\
4 / 3\end{array}$ & Brown & $\begin{array}{l}\text { Sandy } \\
\text { Loam }\end{array}$ & $\begin{array}{l}1-5 \% \text { Calcium } \\
\text { Carbonate }\end{array}$ & Negative & $\begin{array}{l}\text { No cultural material } \\
\text { encountered. Terminated } \\
\text { at basal clay. }\end{array}$ \\
\hline SS101 & $0-45$ & $\begin{array}{l}7.5 \mathrm{YR} \\
4 / 3\end{array}$ & Brown & $\begin{array}{l}\text { Sandy } \\
\text { Loam }\end{array}$ & $\begin{array}{l}10-20 \% \text { Mottles, Black } \\
\text { sand }\end{array}$ & Negative & $\begin{array}{l}\text { No cultural material } \\
\text { encountered. Terminated } \\
\text { at basal clay. }\end{array}$ \\
\hline SS102 & $0-30$ & $\begin{array}{l}7.5 \mathrm{YR} \\
4 / 3\end{array}$ & Brown & $\begin{array}{l}\text { Sandy } \\
\text { Loam }\end{array}$ & $\begin{array}{l}10-20 \% \text { Mottles, Black } \\
\text { sand }\end{array}$ & Negative & $\begin{array}{l}\text { No cultural material } \\
\text { encountered. Terminated } \\
\text { at basal clay. }\end{array}$ \\
\hline SS103 & $0-40$ & $\begin{array}{l}7.5 \mathrm{YR} \\
4 / 4\end{array}$ & Brown & $\begin{array}{l}\text { Sandy } \\
\text { Loam }\end{array}$ & 1-5\% Cobbles & Negative & $\begin{array}{l}\text { No cultural material } \\
\text { encountered. Terminated } \\
\text { at basal clay. }\end{array}$ \\
\hline SS104 & $0-50$ & $\begin{array}{l}7.5 \mathrm{YR} \\
4 / 4\end{array}$ & Brown & $\begin{array}{l}\text { Sandy } \\
\text { Loam }\end{array}$ & 1-5\% Cobbles & Negative & $\begin{array}{l}\text { No cultural material } \\
\text { encountered. Terminated } \\
\text { at basal clay. }\end{array}$ \\
\hline SS105 & $0-65$ & $\begin{array}{l}7.5 \mathrm{YR} \\
4 / 6\end{array}$ & $\begin{array}{l}\text { Strong } \\
\text { Brown }\end{array}$ & $\begin{array}{l}\text { Sandy } \\
\text { Loam }\end{array}$ & 1-5\% Cobbles & Negative & $\begin{array}{l}\text { No cultural material } \\
\text { encountered. Terminated } \\
\text { at basal clay. }\end{array}$ \\
\hline SS106 & $0-30$ & $\begin{array}{l}7.5 Y R \\
4 / 6\end{array}$ & $\begin{array}{l}\text { Strong } \\
\text { Brown }\end{array}$ & $\begin{array}{l}\text { Sandy } \\
\text { Loam }\end{array}$ & 1-5\% Cobbles & Negative & $\begin{array}{l}\text { No cultural material } \\
\text { encountered. Terminated } \\
\text { at basal clay. }\end{array}$ \\
\hline SS107 & $0-30$ & $\begin{array}{l}7.5 Y R \\
4 / 6\end{array}$ & $\begin{array}{l}\text { Strong } \\
\text { Brown }\end{array}$ & $\begin{array}{l}\text { Sandy } \\
\text { Loam }\end{array}$ & 1-5\% Cobbles & Negative & $\begin{array}{l}\text { No cultural material } \\
\text { encountered. Terminated } \\
\text { at basal clay. }\end{array}$ \\
\hline SS108 & $0-30$ & $\begin{array}{l}7.5 \mathrm{YR} \\
4 / 4\end{array}$ & Brown & $\begin{array}{l}\text { Sandy } \\
\text { Loam }\end{array}$ & $>20 \%$ Mottles & Negative & $\begin{array}{l}\text { No cultural material } \\
\text { encountered. Terminated } \\
\text { at disturbed or basal at } \\
\text { surface. }\end{array}$ \\
\hline
\end{tabular}




\begin{tabular}{|c|c|c|c|c|c|c|c|}
\hline $\begin{array}{l}\text { STP } \\
\text { No. }\end{array}$ & $\begin{array}{l}\text { Depth } \\
\text { (cmbs) }\end{array}$ & Munsell & Soil Color & $\begin{array}{l}\text { Soil } \\
\text { Texture }\end{array}$ & Inclusions & $\begin{array}{l}\text { Positive/ } \\
\text { Negative }\end{array}$ & $\begin{array}{l}\text { Comments/ } \\
\text { Reason for Termination }\end{array}$ \\
\hline \multirow[b]{2}{*}{ SS109 } & $0-60$ & $\begin{array}{l}7.5 \mathrm{YR} \\
5 / 4\end{array}$ & Brown & $\begin{array}{l}\text { Sandy } \\
\text { Loam }\end{array}$ & $1-5 \%$ Cobbles & Negative & $\begin{array}{l}\text { No cultural material } \\
\text { encountered. }\end{array}$ \\
\hline & $60-65$ & $\begin{array}{l}7.5 Y R \\
4 / 3\end{array}$ & Brown & $\begin{array}{l}\text { Sandy } \\
\text { Clay } \\
\text { Loam }\end{array}$ & 1-5\% Cobbles & Negative & $\begin{array}{l}\text { No cultural material } \\
\text { encountered. Terminated } \\
\text { at basal clay. }\end{array}$ \\
\hline SS110 & $0-70$ & $\begin{array}{l}7.5 \mathrm{YR} \\
5 / 4\end{array}$ & Brown & $\begin{array}{l}\text { Sandy } \\
\text { Loam }\end{array}$ & $1-5 \%$ Cobbles & Negative & $\begin{array}{l}\text { No cultural material } \\
\text { encountered. Terminated } \\
\text { at basal clay. }\end{array}$ \\
\hline SS111 & $0-40$ & $\begin{array}{l}7.5 \mathrm{YR} \\
5 / 4\end{array}$ & Brown & $\begin{array}{l}\text { Sandy } \\
\text { Loam }\end{array}$ & 1-5\% Cobbles & Negative & $\begin{array}{l}\text { No cultural material } \\
\text { encountered. Terminated } \\
\text { at basal clay. }\end{array}$ \\
\hline SS112 & $0-20$ & $\begin{array}{l}7.5 \mathrm{YR} \\
4 / 4\end{array}$ & Brown & $\begin{array}{l}\text { Sandy } \\
\text { Loam }\end{array}$ & $\begin{array}{l}1-5 \% \text { Calcium } \\
\text { Carbonate }\end{array}$ & Negative & $\begin{array}{l}\text { No cultural material } \\
\text { encountered. Terminated } \\
\text { at basal clay. }\end{array}$ \\
\hline
\end{tabular}


Cultural Resources Investigations

for the CrownQuest City of Midland Oil and Gas Project

This page intentionally left blank. 


\section{APPENDIX C}

\section{Auger Test Results}


This page intentionally left blank. 


\begin{tabular}{|c|c|c|c|c|c|c|c|}
\hline $\begin{array}{l}\text { Auger } \\
\text { test } \\
\text { No. }\end{array}$ & $\begin{array}{l}\text { Depth } \\
\text { (cmbs) }\end{array}$ & Munsell & $\begin{array}{l}\text { Soil } \\
\text { Color }\end{array}$ & $\begin{array}{l}\text { Soil } \\
\text { Texture }\end{array}$ & Inclusions & $\begin{array}{l}\text { Positivel } \\
\text { Negative }\end{array}$ & $\begin{array}{l}\text { Comments/Reason for } \\
\text { Termination }\end{array}$ \\
\hline \multirow{4}{*}{ AUGER01 } & $0-55$ & $\begin{array}{l}7.5 \mathrm{YR} \\
4 / 4\end{array}$ & Brown & $\begin{array}{l}\text { Sandy } \\
\text { Loam }\end{array}$ & $\begin{array}{l}\text { 1-5\% Calcium } \\
\text { Carbonate, } \\
\text { Gravels, Pebbles }\end{array}$ & Negative & $\begin{array}{l}\text { No cultural material } \\
\text { encountered. }\end{array}$ \\
\hline & $55-70$ & $\begin{array}{l}7.5 \mathrm{YR} \\
5 / 4\end{array}$ & Brown & $\begin{array}{l}\text { Sandy } \\
\text { Loam }\end{array}$ & $\begin{array}{l}10-20 \% \text { Calcium } \\
\text { Carbonate, } \\
\text { Cobbles, Gravels, } \\
\text { Pebbles }\end{array}$ & Negative & $\begin{array}{l}\text { No cultural material } \\
\text { encountered. }\end{array}$ \\
\hline & $70-110$ & $\begin{array}{l}7.5 \mathrm{YR} \\
6 / 4\end{array}$ & $\begin{array}{l}\text { Light } \\
\text { Brown }\end{array}$ & $\begin{array}{l}\text { Sandy } \\
\text { Loam }\end{array}$ & $\begin{array}{l}>20 \% \text { Calcium } \\
\text { Carbonate, } \\
\text { Cobbles, Gravels, } \\
\text { Pebbles }\end{array}$ & Negative & $\begin{array}{l}\text { No cultural material } \\
\text { encountered. }\end{array}$ \\
\hline & $110-165$ & $\begin{array}{l}7.5 \mathrm{YR} \\
7 / 4\end{array}$ & Pink & $\begin{array}{l}\text { Sandy } \\
\text { Loam }\end{array}$ & $\begin{array}{l}>20 \% \text { Calcium } \\
\text { Carbonate, } \\
\text { Cobbles, Gravels, } \\
\text { Pebbles }\end{array}$ & Negative & $\begin{array}{l}\text { No cultural material } \\
\text { encountered. Terminated at } \\
\text { compact soil. }\end{array}$ \\
\hline \multirow{4}{*}{ AUGER02 } & $0-65$ & $\begin{array}{l}7.5 Y R \\
6 / 6\end{array}$ & $\begin{array}{l}\text { Reddish } \\
\text { yellow }\end{array}$ & $\begin{array}{l}\text { Sandy } \\
\text { Loam }\end{array}$ & $\begin{array}{l}1-5 \% \text { Calcium } \\
\text { Carbonate, } \\
\text { Cobbles, Gravels, } \\
\text { Pebbles }\end{array}$ & Negative & $\begin{array}{l}\text { No cultural material } \\
\text { encountered. }\end{array}$ \\
\hline & $65-90$ & $\begin{array}{l}7.5 \mathrm{YR} \\
5 / 4\end{array}$ & Brown & $\begin{array}{l}\text { Sandy } \\
\text { Loam }\end{array}$ & $\begin{array}{l}5-10 \% \text { Calcium } \\
\text { Carbonate, } \\
\text { Cobbles, Gravels, } \\
\text { Pebbles }\end{array}$ & Negative & $\begin{array}{l}\text { No cultural material } \\
\text { encountered. }\end{array}$ \\
\hline & $90-190$ & $\begin{array}{l}7.5 \mathrm{YR} \\
6 / 4\end{array}$ & $\begin{array}{l}\text { Light } \\
\text { Brown }\end{array}$ & $\begin{array}{l}\text { Sandy } \\
\text { Loam }\end{array}$ & $\begin{array}{l}10-20 \% \text { Calcium } \\
\text { Carbonate, } \\
\text { Cobbles, Gravels, } \\
\text { Pebbles }\end{array}$ & Negative & $\begin{array}{l}\text { No cultural material } \\
\text { encountered. }\end{array}$ \\
\hline & $190-195$ & $\begin{array}{l}7.5 \mathrm{YR} \\
6 / 4\end{array}$ & $\begin{array}{l}\text { Light } \\
\text { Brown }\end{array}$ & $\begin{array}{l}\text { Sandy } \\
\text { Clay } \\
\text { Loam }\end{array}$ & $\begin{array}{l}>20 \% \text { Calcium } \\
\text { Carbonate }\end{array}$ & Negative & $\begin{array}{l}\text { No cultural material } \\
\text { encountered. Terminated at } \\
\text { basal clay. }\end{array}$ \\
\hline AUGER03 & $0-17$ & $\begin{array}{l}7.5 \mathrm{YR} \\
4 / 4\end{array}$ & Brown & $\begin{array}{l}\text { Sandy } \\
\text { Loam }\end{array}$ & $\begin{array}{l}>20 \% \text { Calcium } \\
\text { Carbonate, } \\
\text { Cobbles, Gravels, } \\
\text { Pebbles }\end{array}$ & Negative & $\begin{array}{l}\text { No cultural material } \\
\text { encountered. Terminated at } \\
\text { bedrock. }\end{array}$ \\
\hline \multirow[b]{2}{*}{ AUGER04 } & $0-70$ & $\begin{array}{l}7.5 \mathrm{YR} \\
5 / 3\end{array}$ & Brown & $\begin{array}{l}\text { Sandy } \\
\text { Loam }\end{array}$ & $\begin{array}{l}\text { 1-5\% Calcium } \\
\text { Carbonate }\end{array}$ & Negative & $\begin{array}{l}\text { No cultural material } \\
\text { encountered. }\end{array}$ \\
\hline & $70-210$ & $\begin{array}{l}7.5 \mathrm{YR} \\
6 / 4\end{array}$ & $\begin{array}{l}\text { Light } \\
\text { Brown }\end{array}$ & $\begin{array}{l}\text { Sandy } \\
\text { Loam }\end{array}$ & $\begin{array}{l}1-5 \% \text { Calcium } \\
\text { Carbonate }\end{array}$ & Negative & $\begin{array}{l}\text { No cultural material } \\
\text { encountered. Terminated at } \\
\text { bedrock. }\end{array}$ \\
\hline \multirow{3}{*}{ AUGER05 } & $0-70$ & $\begin{array}{l}7.5 \mathrm{YR} \\
5 / 3\end{array}$ & Brown & $\begin{array}{l}\text { Sandy } \\
\text { Loam }\end{array}$ & $\begin{array}{l}1-5 \% \text { Calcium } \\
\text { Carbonate }\end{array}$ & Negative & $\begin{array}{l}\text { No cultural material } \\
\text { encountered. }\end{array}$ \\
\hline & $70-135$ & $\begin{array}{l}7.5 \mathrm{YR} \\
6 / 4\end{array}$ & $\begin{array}{l}\text { Light } \\
\text { Brown }\end{array}$ & $\begin{array}{l}\text { Sandy } \\
\text { Loam }\end{array}$ & $\begin{array}{l}1-5 \% \text { Calcium } \\
\text { Carbonate }\end{array}$ & Negative & $\begin{array}{l}\text { No cultural material } \\
\text { encountered. }\end{array}$ \\
\hline & $135-165$ & 5YR 5/6 & $\begin{array}{l}\text { Yellowish } \\
\text { Red }\end{array}$ & $\begin{array}{l}\text { Sandy } \\
\text { Loam }\end{array}$ & $\begin{array}{l}\text { 1-5\% Calcium } \\
\text { Carbonate }\end{array}$ & Negative & $\begin{array}{l}\text { No cultural material } \\
\text { encountered. Terminated at } \\
\text { bedrock. }\end{array}$ \\
\hline \multirow{3}{*}{ AUGER06 } & $0-70$ & $\begin{array}{l}7.5 \mathrm{YR} \\
5 / 3\end{array}$ & Brown & $\begin{array}{l}\text { Sandy } \\
\text { Loam }\end{array}$ & $\begin{array}{l}1-5 \% \text { Calcium } \\
\text { Carbonate }\end{array}$ & Negative & $\begin{array}{l}\text { No cultural material } \\
\text { encountered. }\end{array}$ \\
\hline & $70-135$ & $\begin{array}{l}7.5 \mathrm{YR} \\
6 / 4\end{array}$ & $\begin{array}{l}\text { Light } \\
\text { Brown }\end{array}$ & $\begin{array}{l}\text { Sandy } \\
\text { Loam }\end{array}$ & $\begin{array}{l}1-5 \% \text { Calcium } \\
\text { Carbonate }\end{array}$ & Negative & $\begin{array}{l}\text { No cultural material } \\
\text { encountered. }\end{array}$ \\
\hline & $135-170$ & 5YR 5/6 & $\begin{array}{l}\text { Yellowish } \\
\text { Red }\end{array}$ & $\begin{array}{l}\text { Sandy } \\
\text { Loam }\end{array}$ & $\begin{array}{l}1-5 \% \text { Calcium } \\
\text { Carbonate }\end{array}$ & Negative & $\begin{array}{l}\text { No cultural material } \\
\text { encountered. Terminated at } \\
\text { bedrock. }\end{array}$ \\
\hline
\end{tabular}




\begin{tabular}{|c|c|c|c|c|c|c|c|}
\hline $\begin{array}{l}\text { Auger } \\
\text { test } \\
\text { No. }\end{array}$ & $\begin{array}{l}\text { Depth } \\
\text { (cmbs) }\end{array}$ & Munsell & $\begin{array}{l}\text { Soil } \\
\text { Color }\end{array}$ & $\begin{array}{l}\text { Soil } \\
\text { Texture }\end{array}$ & Inclusions & $\begin{array}{l}\text { Positive/ } \\
\text { Negative }\end{array}$ & $\begin{array}{l}\text { Comments/Reason for } \\
\text { Termination }\end{array}$ \\
\hline \multirow{3}{*}{ AUGER07 } & $0-80$ & $\begin{array}{l}10 Y R \\
5 / 4\end{array}$ & $\begin{array}{l}\text { Yellowish } \\
\text { Brown }\end{array}$ & $\begin{array}{l}\text { Sandy } \\
\text { Loam }\end{array}$ & $\begin{array}{l}\text { 1-5\% Calcium } \\
\text { Carbonate }\end{array}$ & Negative & $\begin{array}{l}\text { No cultural material } \\
\text { encountered. }\end{array}$ \\
\hline & $80-110$ & $\begin{array}{l}10 Y R \\
4 / 4\end{array}$ & $\begin{array}{l}\text { dark } \\
\text { Yellowish } \\
\text { Brown }\end{array}$ & $\begin{array}{l}\text { Sandy } \\
\text { Loam }\end{array}$ & $\begin{array}{l}1-5 \% \text { Calcium } \\
\text { Carbonate }\end{array}$ & Negative & $\begin{array}{l}\text { No cultural material } \\
\text { encountered. }\end{array}$ \\
\hline & $110-115$ & 5YR 4/4 & $\begin{array}{l}\text { Reddish } \\
\text { Brown }\end{array}$ & $\begin{array}{l}\text { Sandy } \\
\text { Clay }\end{array}$ & $\begin{array}{l}10-20 \% \text { Calcium } \\
\text { Carbonate }\end{array}$ & Negative & $\begin{array}{l}\text { No cultural material } \\
\text { encountered. Terminated at } \\
\text { basal clay. }\end{array}$ \\
\hline
\end{tabular}

